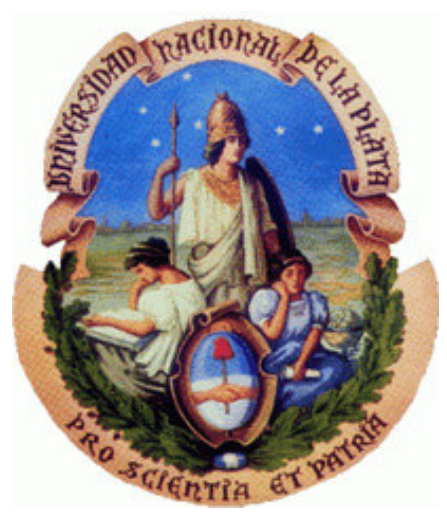

Universidad Nacional de La Plata Departamento de Cs. Biológicas

\author{
Tesis Doctoral
}

\title{
Análisis de componentes de gránulos ribonucleoproteicos en Drosophila.
}

\section{Licenciada en Bioquímica Carla Layana \\ Director: Dr. Rolando Rivera Pomar \\ Asesor académico: Dr. Antonio Lagares}

2012 
El presente trabajo de Tesis se realizó en el Laboratorio de Genética y Genómica Funcional del Centro Regional de Estudios Genómicos de la Universidad Nacional de La Plata. Bajo la dirección del Dr. Rolando Rivera Pomar. Se presenta a consideración de las autoridades de la Facultad de Ciencias Exactas, de la Universidad Nacional de La Plata a fin de acceder al Grado Académico de Doctor de la Facultad de Ciencias Exactas. 


\section{Resumen}

La regulación de la expresión génica es un proceso altamente regulado, que controla qué genes son expresados en cada momento. Uno de los controles más dinámicos del proteoma celular es la regulación de la traducción. El control de la expresión de los mensajeros celulares se ha relacionado hace algunos años con dos estructuras de silenciamiento particulares, los PB (de processing bodies) y los SG (de stress granules). Ambas son formaciones citoplasmáticas que acumulan ARNm y proteínas. Los $\mathrm{PB}$ son estructuras constitutivas de las células mientras que los SG aparecen frente a estímulos de estrés celular.

En la primera parte de esta tesis se realizó una caracterización de los PB en células S2 Drosophila melanogaster. Particularmente demostramos la presencia de las proteínas Lsm-1, Me31B y eIF4E en los PB. Durante estrés inducido por arsenito de sodio se encontró a eIF4E en SG.

Se realizó un estudio más minucioso sobre eIF4E. El análisis de diversos mutantes demostró que el residuo W117, parte del dominio de unión a las 4E-BP, es el responsable de la ubicación de este factor en PB y SG. Mientras que los residuos que participan en la unión al cap de los mensajeros (W100 y W 146) no están involucrados en este proceso.

Finalmente se realizó el estudio de interacciones entre estos componentes en PB de células S2 in vivo mediante FRET. Se demostró que las proteínas Lsm-1 y Me31B interaccionan con eIF4E. Sin embargo no pudo ser demostrada por este método la interacción entre Me31B y Lsm-1. Se realizó la predicción de posibles sitios de interacción entre eIF4E y Me31B mediante modelado por homología.

Palabras clave: complejos ribonucleproteicos, ARNm, PB, SG, Drosophila, regulación de la traducción. 


\section{Índice}

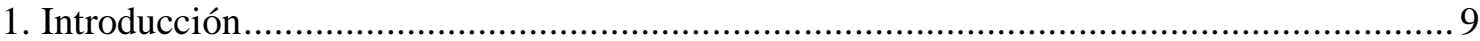

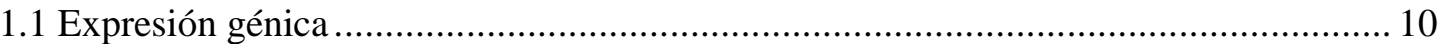

1.1.1 Mecanismos de regulación de la expresión de genes .......................................... 10

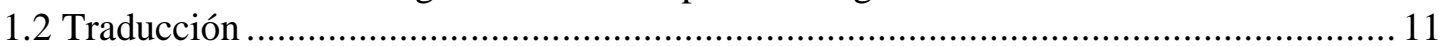

1.2.1 Iniciación de la traducción del ARNm en eucariotas ........................................... 11

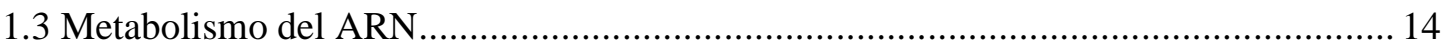

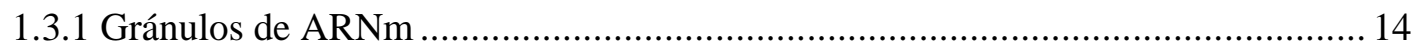

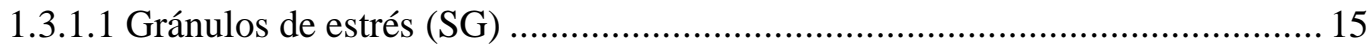

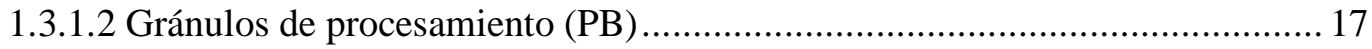

1.3.1.2.1 Rol de los PB en el metabolismo de ARNm ...................................... 19

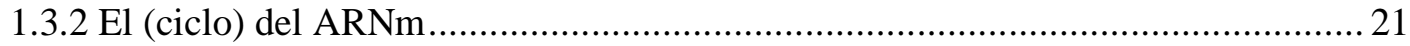

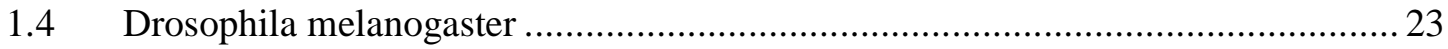

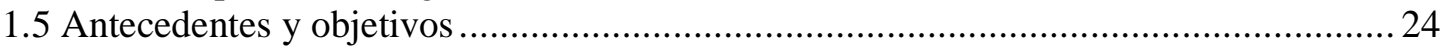

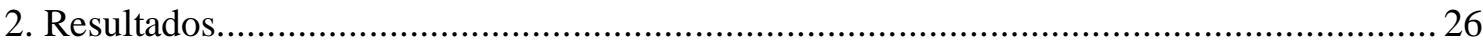

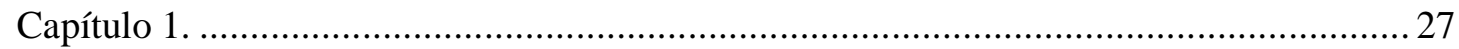

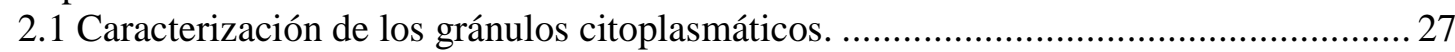

2.1.1 Me31B es un componente de PB de una subpoblación de células S2 .................. 27

2.1.2 Lsm-1 se encuentra en PB y no en SG en células de $D m$.................................... 31

2.1.3 eIF4E es un componente que participa en la traducción de mensajeros y en su

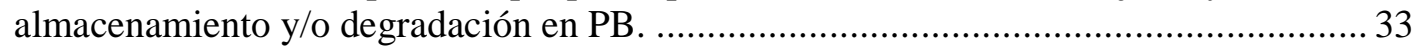

2.1.4 Análisis de co-localización entre componentes de gránulos................................. 39

2.1.4.1 eIF4E y Me31B co-localizan en PB en células S2 de Drosophila melanogaster

2.1.4.2 eIF4E y Lsm-1 co-localizan en PB en células S2 de Drosophila melanogaster

2.1.4.3 Lsm-1 y Me31B co-localizan en PB en células S2 de Drosophila melanogaster

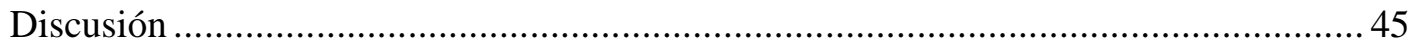

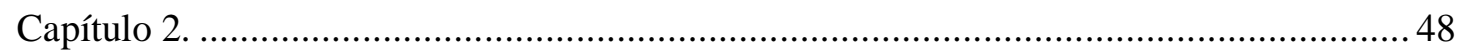

2.2. Estudio funcional de eIF4E en el reclutamiento hacia PB. .................................... 48

2.2.1 El reclutamiento de eIF4E hacia PB es independiente de su actividad de unión al

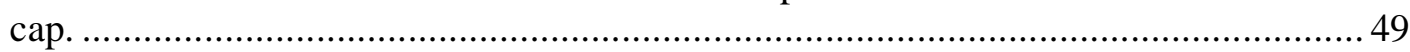

2.2.2 El reclutamiento de eIF4E hacia PB requiere el aminoácido W117 .................... 57

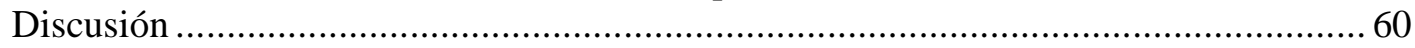

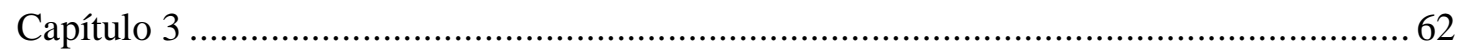

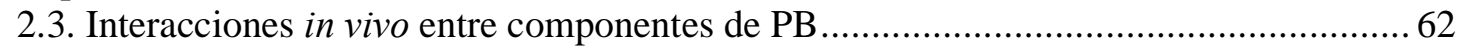

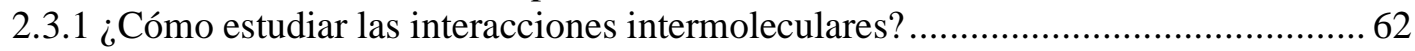

2.3.1.1 Microscopía del interactoma: la bioquímica celular in vivo. .........................65 65

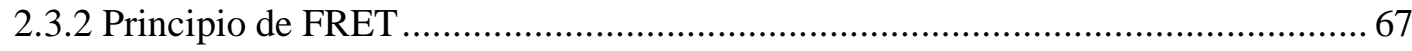

2.3.2.1 FRET para ver interacciones entre moléculas en células............................. 71

2.3.2.2 Diseño de los pares de FRET y elección de los fluoróforos. .........................73 73

2.3.2.3 Establecimiento de parámetros experimentales............................................. 74

2.3.3 eIF4E interacciona con Me31B y con Lsm-1 en PB en células S2 de Drosophila

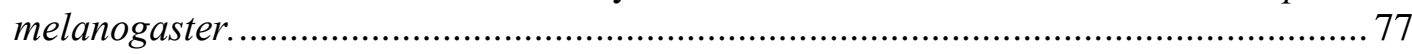

2.3.4 Me31B y Lsm-1 no demuestran interacción por FRET.......................................... 80

2.3.5 Predicción de sitios de interacción mediante modelado por homología................. 81

2.3.5.1 Construcción de los modelos de Me31B y eIF4E. ...................................... 81 


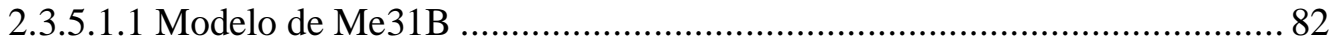

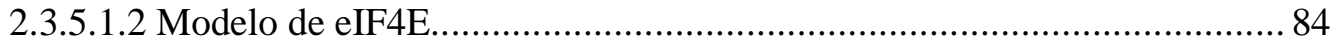

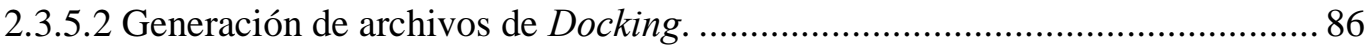

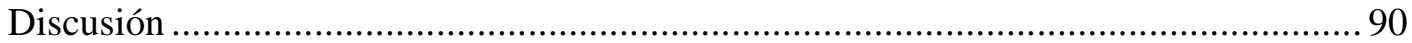

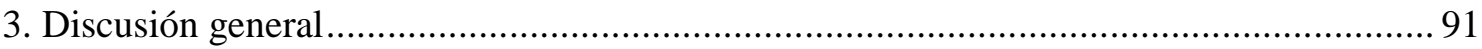

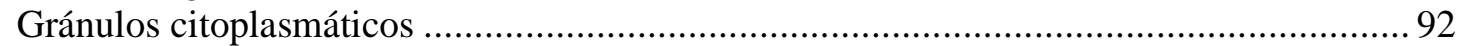

Las dos caras del factor de inicio de la traducción eucariota. .......................................... 95

Lsm-1 y Me31B como proteínas nucleadoras de PB .................................................. 99

Modelo de remodelamiento: de polisomas a gránulos de silenciamiento........................ 101

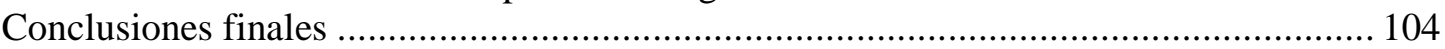

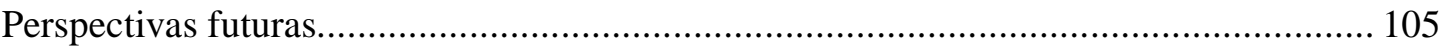

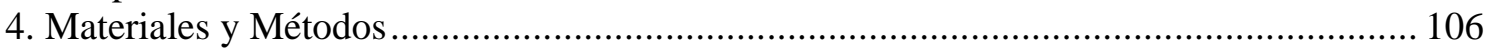

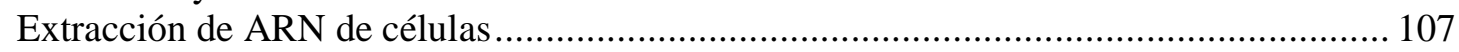

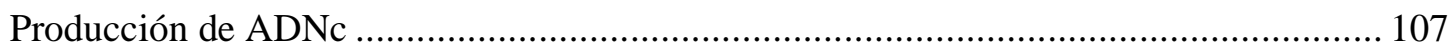

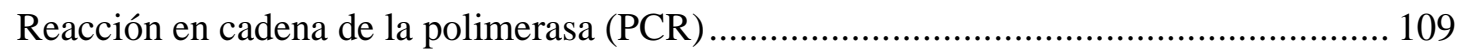

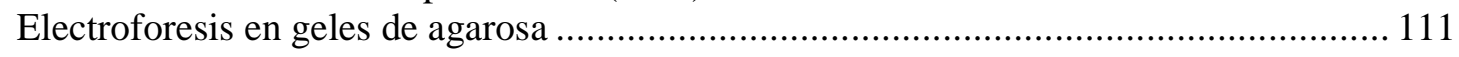

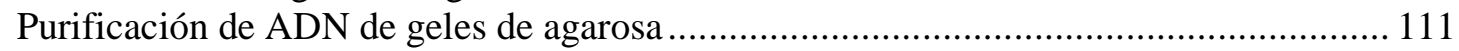

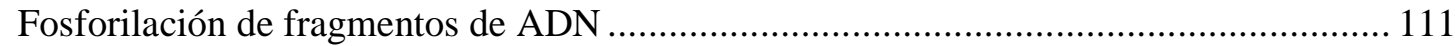

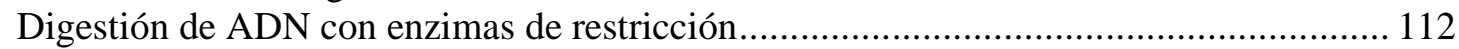

Desfosforilación de plásmidos cortados con enzimas de restricción............................... 112

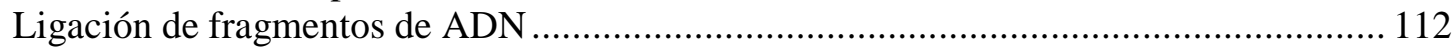

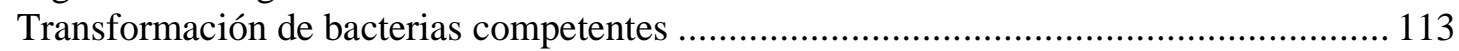

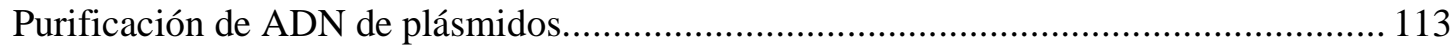

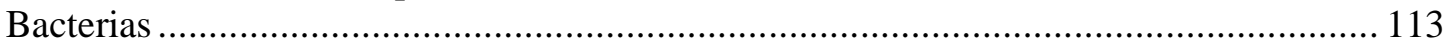

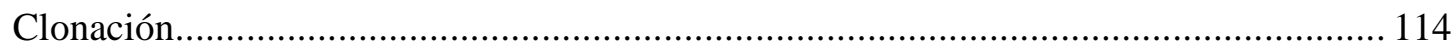

Generación de vectores capaces de expresar proteínas de fusión fluorescentes .............. 114

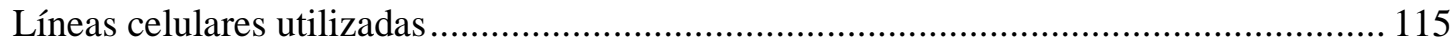

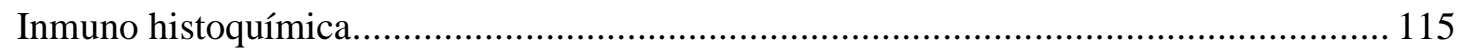

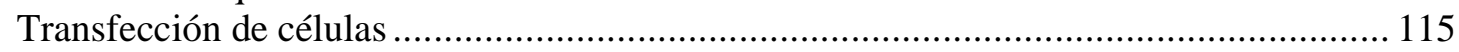

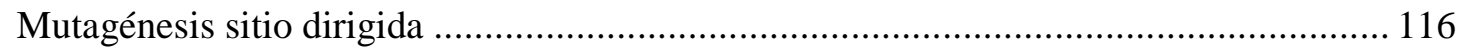

Preparación de células fijadas para ensayos de FRET .................................................... 116

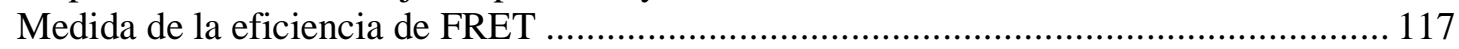

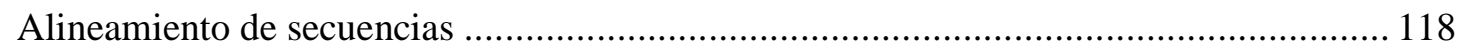

Modelado por homología y generación de archivos de Docking ................................. 118

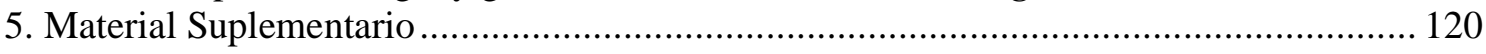

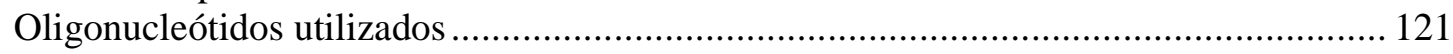

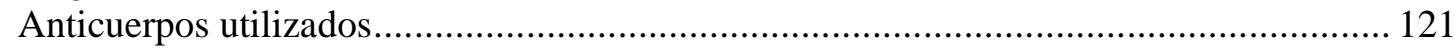

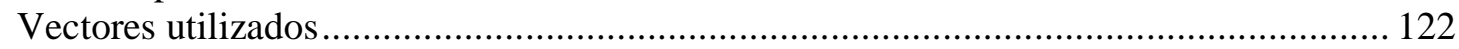

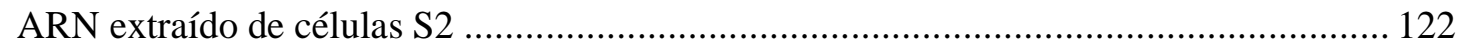

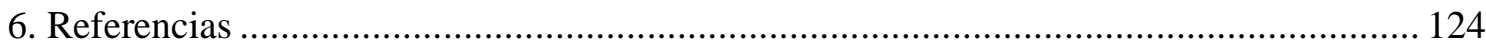




\section{Abreviaturas}

\begin{tabular}{|c|c|}
\hline $\mathrm{ADN}$ & ácido desoxirribonucleico \\
\hline $\mathrm{ADNc}$ & ADN complementario \\
\hline ADNsc & ADN simple cadena \\
\hline ARN & ácido ribonucleico \\
\hline ARNm & ARN mensajero \\
\hline ARNt & ARN transferencia \\
\hline siARN & small interfering ARN \\
\hline miARN & micro ARN \\
\hline Met & Metionina \\
\hline eIF & factor de inicio de la traducción eucariota \\
\hline 4E-BP & proteínas de unión a eIF4E \\
\hline CPI & complejos de pre iniciación \\
\hline $\mathrm{PB}$ & processing bodies \\
\hline SG & gránulos de estrés (stress granules) \\
\hline mRNP & complejos ribonucleoproteicos \\
\hline GDP & guanosina bifosfato \\
\hline GTP & guanosina trifosfato \\
\hline SiARN & small interfering ARN \\
\hline miARN & micro ARN \\
\hline IREs & sitios de unión interna del ribosoma \\
\hline RISC & RNA-induced silencing complex \\
\hline$D m$ & Drosophila melanogaster \\
\hline $\mathrm{T}$ & Treonina \\
\hline $\mathrm{W}$ & Triptofano \\
\hline $\mathrm{S}$ & Serina \\
\hline $\mathrm{K}$ & Lisina \\
\hline FRET & Trasferencia de energía de fluorescencia por resonancia \\
\hline ELISA & ensayo enzimático de inmuno absorción \\
\hline FLIM & Fluorescence Lifetime Imaging \\
\hline 3'UTR & región 3' no traducida \\
\hline $\min$ & minutos \\
\hline PCR & reacción en cadena de la polimerasa \\
\hline PCA & ensayos de complementación de fragmentos de proteínas \\
\hline SFB & Suero fetal bovino \\
\hline PFA & paraformaldehído \\
\hline ROIs & regiones de interés \\
\hline
\end{tabular}





\section{Introducción}




\subsection{Expresión génica}

Los ácidos nucleicos (ADN y ARN) tienen una importancia central en el almacenamiento, la transferencia y la expresión de la información genética. La información genética de todas las células está contenida en su ADN (a excepción de los virus de ARN). Durante la división celular esta información es copiada para que cada célula hija se lleve una copia. En todos los organismos, inclusive los eucariotas, el contenido del ADN de todas sus células es idéntico. Esto quiere decir que contienen toda la información necesaria para la síntesis de todas las proteínas. Pero no todos los genes se expresan al mismo tiempo ni en todas las células. Hay sólo un grupo de genes que se expresan en todas las células del organismo y codifican proteínas que son esenciales para el funcionamiento general de las células. El resto de los genes se expresan o no en los diferentes tipos de células, dependiendo de la función de la célula en un tejido particular. También existe especificidad temporal, esto quiere decir que los diferentes genes en una célula se "encienden" o se "apagan" en diferentes momentos de la vida de un organismo. Esto demuestra la necesidad de un proceso altamente organizado y regulado en todos sus pasos. En la expresión de la información genética contenida en un segmento de ADN siempre interviene la generación de una molécula de ARN. Posteriormente esta molécula de ARN es traducida a moléculas de proteínas en el proceso de traducción.

\subsubsection{Mecanismos de regulación de la expresión de genes}

La regulación de la expresión génica constituye un aspecto fundamental en la regulación global del metabolismo celular. Debido al alto coste energético de la síntesis proteica, la regulación de la expresión génica es esencial para que la célula pueda hacer un uso óptimo de la energía disponible. Las células deben controlar la expresión de sus genes minuciosamente, lo hacen de manera eficiente en cada etapa. Existen muchos puntos en los cuáles se pueden regular los niveles de una proteína, y todos ellos son puntos de control muy importantes. Entre ellos se pueden destacar: síntesis del transcripto primario de ARN (a nivel transcripcional), procesamiento post 
transcripcional del ARN, degradación del ARN, traducción, modificación posttraducción de proteínas y degradación proteica. De todos los procesos mencionados, la regulación del inicio de la transcripción es la más estudiada y parece ser la más común, como en toda ruta biosintética, el lugar más eficiente para su regulación es la primera etapa. Sin embargo, en las células ha tomado gran relevancia la regulación a nivel de la traducción, o sea a nivel del ARNm, ya que permite cambios rápidos de la composición y/o concentración de proteínas en respuesta al entorno.

\subsection{Traducción}

El proceso de traducción consiste en la generación de proteínas a partir del ARN. Se lo puede dividir en tres etapas principales: iniciación, elongación y terminación. Además algunos autores incluyen una cuarta etapa para el reciclado del ribosoma.

Existen mecanismos de regulación en todas las etapas, pero la iniciación es la etapa mas regulada. En esta se produce el reconocimiento del codón de inicio AUG por el Met-ARNt. El mecanismo de selección del codón de inicio difiere entre organismos procariotas y eucariotas, y en consecuencia también lo hacen las estrategias para la regulación de la iniciación.

La fase de elongación corresponde a la síntesis polipeptídica, hasta la aparición de un codón de stop que indica la terminación y liberación del polipéptido del ribosoma (Preiss and W. Hentze, 2003)

\subsubsection{Iniciación de la traducción del ARNm en eucariotas}

El ARNm llega al citoplasma celular para ser traducido. El control de la traducción de estos ARNm permite cambios rápidos en la concentración de proteínas celulares, a diferencia de un control a nivel transcripcional que origina cambios mucho más lentos. (Sonenberg and Hinnebusch, 2009).

Las etapas tempranas del inicio de la traducción conforman el posicionamiento del codón de inicio AUG del ARNm en el sitio P del ribosoma hibridado con el anticodón Met-ARNt: complejos de pre-iniciación (CPI) 43S preensamblados, que contienen Met-ARNt, y factores de inicio eIFs $1,1^{\mathrm{a}}, 2,3$ y 5, son reclutados al 5' cap del ARNm 
ayudado por eIF4E, eIF4G y eIF4A (complejo eIF4F). El Met-ARNt se une al CPI por medio de eIF2-GTP cuando hay un apareamiento correcto codón de inicio- anticodón. Esto provoca la hidrólisis de eIF2-GTP a eIF2-GDP que trae como consecuencia la liberación de eIF2 y otros factores (eIF4F, eIF4B) (Jackson et al., 2010). Seguidamente se produce el ensamblado de la subunidad 60S y se inicia la elongación (Fig.1).

Un grupo de ARNm eucarióticos pueden sortear el proceso de escaneado mediante secuencias especializadas llamadas sitios de unión interna del ribosoma (IREs), las cuales reclutan el complejo de preiniciación al codón de inicio (Schneider and Kozak, 2001). 


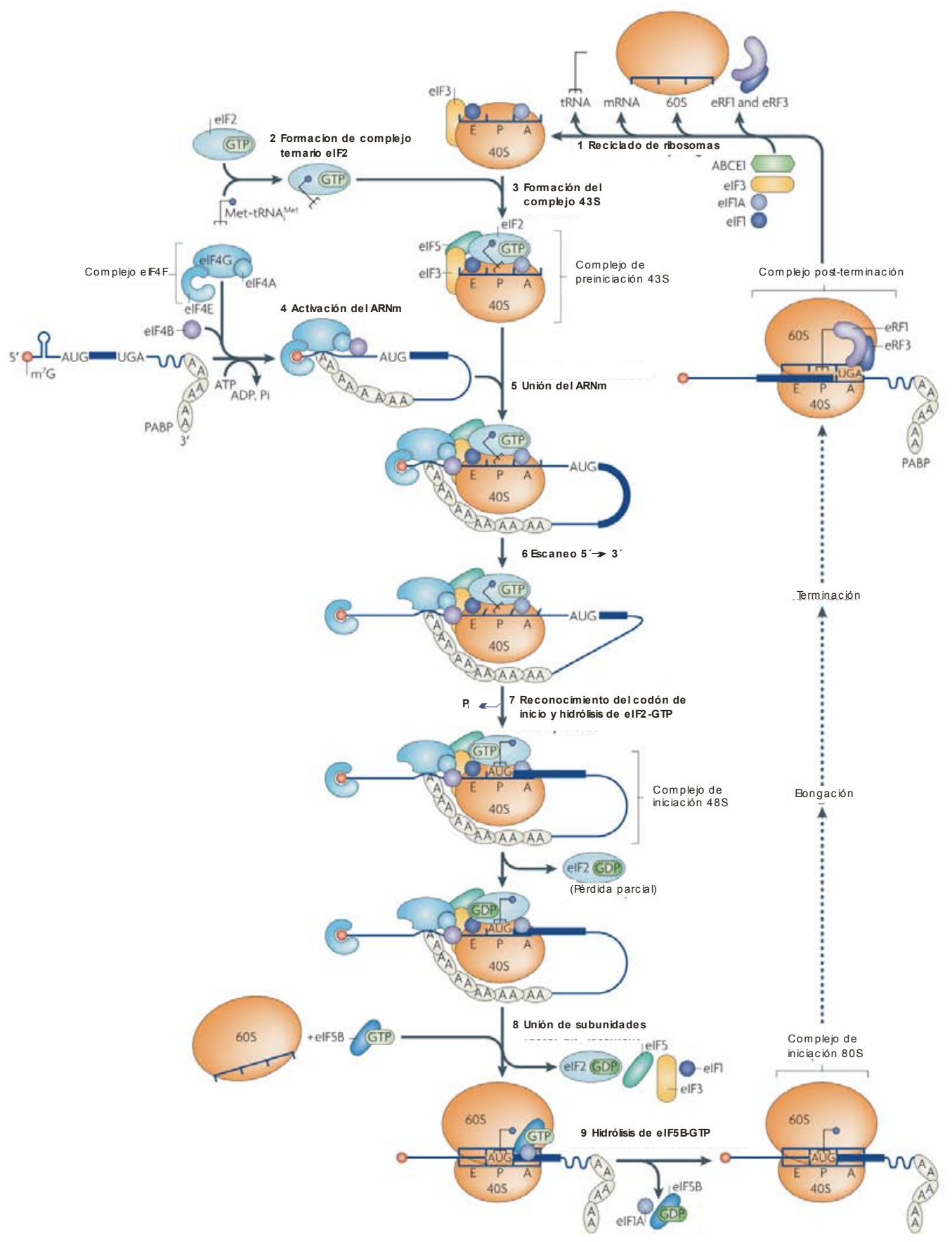

Figura 1. Representación esquemática del inicio de la traducción en eucariotas. El ARNm se une al complejo eIF4F por medio de la interacción de eIF4E con el cap. El complejo de preiniciación 43S (ribosoma 40S, eIF2*GTP-MetARNt, eIF1, eIF1A, eIF5 y eIF3) es reclutado al mensajero por medio de la interacción eIF4G y eIF3 formando el complejo de preiniciación 48S. Este escanea al mensajero hasta encontrar el codón de inicio AUG, se une el ribosoma $60 \mathrm{~S}$ y los factores de iniciación son liberados. (Modificado de Jackson et.al, 2010). 


\subsection{Metabolismo del ARN}

Uno de los procesos de regulación de la expresión génica es el metabolismo del ARN. Este presenta, desde su síntesis (transcripción), transporte, modificación, uso (traducción), almacenamiento o degradación, una serie de etapas de regulación. En los últimos años esta regulación se ubicó, en gran parte, en un tipo de compartimento intracelular aun no bien definido, los cuerpos de procesamiento (PB por processing bodies) (Sheth and Parker, 2003). Los PB son formaciones citoplasmáticas discretas de naturaleza heterogénea en donde se concentran factores de degradación del ARNm y componentes de la maquinaria del ARN de interferencia (ARNi) (Andrei et al., 2005; Cougot et al., 2004; Eystathioy, 2003; Ingelfinger et al., 2002; Sheth and Parker, 2003). El número y tamaño de los PB cambia en respuesta a diferentes condiciones celulares mediante la interferencia de componentes específicos. Allí los ARNm se encuentran formando complejos con proteínas (complejos ribonucleoproteicos: mRNP); los ARN mensajeros son reprimidos a nivel traduccional y degradados, o bien almacenados, hasta que, mediante señales apropiadas, retornen a nuevos ciclos traduccionales (Chan and Slack, 2006; Eulalio et al., 2007b). Esta es una manera adicional mediante la cuál la célula puede controlar los niveles de determinadas proteínas en función de su requerimiento.

\subsubsection{Gránulos de ARNm}

Recientemente han sido descriptos varios gránulos citoplasmáticos que contienen ARN, dos de ellos poseen ARNm silenciados y son de gran interés para el desarrollo de este trabajo: cuerpos de procesamiento (PB por processing bodies) y gránulos de estrés (SG por stress granules). Ambos son estructuras sin membrana, en los cuales se acumulan ARN y proteínas. Los SG se forman transitoriamente en el citoplasma como respuesta al estrés celular y en general tienen un tamaño entre 0,5-5 $\mu \mathrm{m}$ de diámetro. (Thomas et al., 2009). A diferencia de los SG, los PB son estructuras constitutivas que

pueden medir entre 0,1-2 $\mu \mathrm{m}$ de diámetro. Ambos foci son estructuras altamente dinámicas que están en equilibrio con polisomas, respondiendo de esta manera al estado traduccional de la célula. (Kedersha et al., 2005). Son estructuras novedosas 
cuyos componentes siguen siendo estudiados y son de gran relevancia para el estudio de los objetivos propuesto, por lo cual van a ser descriptos con más detalle a continuación.

\subsubsection{Gránulos de estrés (SG)}

Así como el inicio de la traducción es la etapa mas regulada del proceso de síntesis proteica, es la más influenciada por el estrés. Una vía importante para inhibir la traducción en eucariotas es la fosforilación de eIF $2 \alpha$, esto genera un gran aumento en la afinidad de eIF2-GDP por eIF2B, secuestrando dicho factor. De esta manera se evita que se produzcan nuevos eventos de iniciación (Yamasaki and Anderson, 2008).

Al inhibirse la traducción por este mecanismo, se produce el desensamblado de polisomas y la consecuente acumulación de mRNP.

La composición de proteínas y ARN de los gránulos es dinámica y como ya se ha mencionado esta en equilibrio con polisomas. Las drogas que inhiben la elongación de la traducción (por ej.: cicloheximida) previenen el ensamblado de SG, mientras que drogas que generan una terminación prematura de la traducción promueven su formación (Anderson and Kedersha, 2008).

En la tabla 1 se muestran los componentes de los SG, estos se clasifican en tres grupos principales:

- Componentes centrales: complejos de iniciación atascados que contienen ARNm poliadenilado, factores de iniciación (eIF4E, eIF4A, eIF4G eIF3, eIF2, PABP1 y proteínas de la subunidad $40 \mathrm{~S}$ del ribosoma) y un grupo de proteínas que varían según el tipo celular y el tipo de estrés involucrado.

- Proteínas de unión al ARN asociadas al silenciamiento traduccional o a la estabilidad del ARN. Entre ellas podemos destacar la presencia de TIA-1(el ortólogo en Dm es Rox8, CG5422, sin embargo en esta tesis nos referiremos a él como TIA-1), TIAR (Kedersha et al., 1999), FAST, Argonauta (Leung et al., 2006), CPEB, smaug, RCK/p54 (o Dhh1), XRN1 (Kedersha et al., 2005).

- Proteínas de unión al ARN que participan en la regulación del metabolismo del ARNm distintas a la traducción o degradación. Entre ellas se encuentran G3BP (Tourriere et al., 2003), Staufen (Thomas et al., 2005), etc. 
Evaluando todas las investigaciones relacionadas a SG se llega a la conclusión de que serían estructuras encargadas de proteger ARNm durante el estrés, alterando la composición de los complejos mRNP y estableciendo el camino que debe seguir el ARNm.

\begin{tabular}{|c|c|c|}
\hline Proteína & Función conocida & Proteínas de unión \\
\hline Ago2 & Corta al ARNi & RISC, FXR1 \\
\hline APOBEC3G & respuesta antiviral & $?$ \\
\hline Ataxina-2 & Traducción & PABP-1 \\
\hline Caprina-1 & crecimiento celular & G3BP \\
\hline CPEB & silenciamiento de ARNm & RCK,elF4E, FXR1 \\
\hline DIS1 & desconocida & elF3h \\
\hline elF3 & Traducción & $40 S$, elF4G \\
\hline elF4E & Traducción & CPEB, samug, elF4G, 4ET \\
\hline elF4G & Traducción & elF4E, elF3, PABP-1 \\
\hline FAST & Traducción & TIA-1 \\
\hline FMRP y FXR1 & Traducción & Ago2, RISC \\
\hline FBP y KSRP & degradación de ARN & TIA-1 \\
\hline FUS/TLS & Unión al ADN y al ARN & $?$ \\
\hline G3BP & señalización Ras & caprina \\
\hline HuR & estabilización del ARN & $?$ \\
\hline IP5K & señalización & $?$ \\
\hline Lin28 & Desarrollo & $?$ \\
\hline LINE 1 ORF1p & Transposon & $?$ \\
\hline MLN51 & Splicing & Exon junction \\
\hline PABP-1 & traducción, estabilidad & elF4G, elF3, ataxina-2 \\
\hline $\mathrm{RCK}(\mathrm{p} 54)$ & degradación de ARNm & GE-1, TTP \\
\hline Placofilina & Adhesión & G3BP, FXR1 \\
\hline PMR1 & degradación de ARNm & TIA-1 \\
\hline Pumilio 2 & silenciamiento de ARNm & $?$ \\
\hline Rap 55 & silenciamiento de ARNm & $?$ \\
\hline Rpb4 & transcripción & $?$ \\
\hline SRC3 & transcripción & TIA-1 \\
\hline Staufen & silenciamiento de ARNm & $?$ \\
\hline SMN & formación de RNP & complejo SMN \\
\hline TIA-1 y TIAR & silenciamiento de ARNm & FAST,SRC3, PMR1,FBP \\
\hline TDP43 & Unión a ADN y a ARN & $?$ \\
\hline TRAF2 & señalización & elF4G \\
\hline TTP y BRF-1 & silenciamiento de ARNm & RCK (p54) \\
\hline YB-1 & shock por frío & $?$ \\
\hline ZBP1 & Localización & $?$ \\
\hline
\end{tabular}

Tabla 1. Componentes de gránulos de estrés. Se indica la función conocida de cada componente y los interactores relevantes. 


\subsubsection{Gránulos de procesamiento (PB)}

El descubrimiento de estas estructuras data de 1997 cuando Bashkirov y col. observan a la proteína Xrn1 en pequeñas estructuras granulares en el citoplasma de células de mamífero, a las cuáles llamaron Xrn1 foci (Bashkirov et al., 1997). Años más tarde se observó a la proteína Dcp2 en gránulos citoplasmáticos en levaduras (van Dijk et al., 2002), los cuáles posteriormente fueron llamados Dcp foci. Simultáneamente, Eystathioy y col. observaron en suero autoinmune de pacientes que sufrían de neuropatía motora y sensorial, cuerpos citoplasmáticos que contenían una proteína desconocida a la que llamaron GW182, y a los gránulos, cuerpos GW. No tardaron en darse cuenta de que se trataba de las mismas estructuras y se las llamó cuerpos de procesamiento $(\mathrm{PB})$. Actualmente la proteína GW182 se utiliza como un marcador de PB (Eystathioy, 2003).

Los PB concentran proteínas de degradación 5' a 3' del ARNm (Dcp1, Dcp2, Xrn1, etc.) (Eulalio et al., 2007b; Parker and Sheth, 2007). Pareciera que no contienen proteínas ribosomales ni componentes del exosoma (Brengues et al., 2005). Carecen también de factores de inicio de la traducción a excepción de eIF4E, que se halla en PB en células de mamíferos. (Andrei et al., 2005; Ferraiuolo et al., 2005). Sin embargo, eIF4G y PABP fueron encontradas en PB en levaduras en baja cantidad en condiciones de estrés por carencia de glucosa (Brengues and Parker, 2007). En células de mamífero poseen además componentes del silenciamiento mediado por miARN (Argonauta).

En la tabla 2 se resumen los componentes de los PB y sus funciones. 


\begin{tabular}{|c|c|c|}
\hline Proteína & Función conocida & Organismos \\
\hline Xrn1, Sc Kem1 & exonucleas $5^{\prime} \rightarrow 3^{\prime}$ & $\begin{array}{l}\text { Humano, } \\
\text { ratón, Sc }\end{array}$ \\
\hline GW182, Ce AIN-1 & vía miARN & $\begin{array}{l}\text { Humano, Dm, } \\
\text { Ce }\end{array}$ \\
\hline Dcp2, Ce DCAP2 & enzima de decapping & $\begin{array}{l}\text { Humano, Dm, } \\
\text { Ce, Sc }\end{array}$ \\
\hline Dcp1, Ce DCAP1 & subunidad de enzima de decapping & $\begin{array}{l}\text { Humano, Dm, } \\
\text { Ce, Sc }\end{array}$ \\
\hline Hedls, Ge-1 & coactivador de decapping & Humano, Dm \\
\hline Dm CG5208, Pat1 & coactivador de decapping & $\mathrm{Dm}, \mathrm{Sc}$ \\
\hline EDC3 (Lsm16) & coactivador de decapping & $\begin{array}{l}\text { Humano, Dm, } \\
\text { Sc }\end{array}$ \\
\hline Lsm1-7 & complejo coactivador de decapping & Humano, Sc \\
\hline RAP55 & supuesto coactivador de decapping & Humano \\
\hline $\begin{array}{l}\text { RCK/p54, Dm Me31B, } \\
\text { Ce CGH-1, Sc Dhh1 }\end{array}$ & $\begin{array}{c}\text { Coactivador de decapping, regulacion } \\
\text { de la traduccion }\end{array}$ & $\begin{array}{l}\text { Humano, Dm, } \\
\text { Ce, Sc }\end{array}$ \\
\hline elF4E & factor de inicio de la traducción & $\begin{array}{l}\text { Humano, rata, } \\
\text { Dm }\end{array}$ \\
\hline elF4E-T & represor de la traducción & Humano \\
\hline SMG7 & degradación de ARNm sin sentido & Humano \\
\hline SNG5 & degradación de ARNm sin sentido & Humano \\
\hline UPF1, Sc Nam7 & degradación de ARNm sin sentido & Humano, Sc \\
\hline UPF2 & degradación de ARNm sin sentido & Humano \\
\hline UPF3 & degradación de ARNm sin sentido & Humano \\
\hline Argonauta & vías siARN y miARN & $\begin{array}{l}\text { Humano, } \\
\text { Dm,Ce }\end{array}$ \\
\hline $\begin{array}{c}\text { complejo CCR4-CAF1- } \\
\text { NOT } \\
\end{array}$ & deadenilación & Humano, Sc \\
\hline CPEB & regulación de la traducción & Humano \\
\hline FAST & $\begin{array}{l}\text { serina-treonina fosfoproteína activadora } \\
\text { de Fas }\end{array}$ & Humano \\
\hline TTP & degradeción de ARNm ARE & Humano \\
\hline Staufen & $\begin{array}{c}\text { proteína de unión a ARN doble cadena, } \\
\text { localización de ARNm }\end{array}$ & $\mathrm{Dm}$ \\
\hline Rbp1 & $\begin{array}{l}\text { Proteína de unión a ARN,degradacion } \\
\text { de ARNm de porina mitocondrial }\end{array}$ & Sc \\
\hline Rbp4 & Subunidad de la ARN polimerasa II & Sc \\
\hline Sbp1 & supresor de decapping & Sc \\
\hline Germina5 & $\begin{array}{c}\text { formación de ribonucleoproteínas } \\
\text { nucleares pequeñas }\end{array}$ & Humano \\
\hline Dcs2 & $\begin{array}{l}\text { subunidad regulatoria de Dcs1 inducida } \\
\text { por estres }\end{array}$ & Sc \\
\hline $\begin{array}{l}\text { APOBEC3G, } \\
\text { APOBEC3F }\end{array}$ & actividad antiviral & Humano \\
\hline
\end{tabular}

Tabla 2. Componentes de los gránulos de procesamiento. Se indica la función conocida para cada componente.

La presencia de tan amplia gama de proteínas que funcionan en los procesos posttranscripcionales indica un papel central de los PB en la regulación de la expresión génica. Tanto las proteínas como los ARNm pueden entrar y salir de los PB de manera reversible (Brengues et al., 2005). La relación entre la represión traduccional y la 
formación de $\mathrm{PB}$ se aclara con el efecto producido por el tratamiento con cicloheximida; esta droga genera, con la estabilización de polisomas, la pérdida de PB. Mientras que, al igual que en SG, drogas inhibitorias del inicio de la traducción estimulan su ensamblado (Kedersha et al., 2005).

\subsection{Rol de los PB en el metabolismo del ARNm}

\section{PB y decaimiento del ARNm}

El decaimiento de los ARNm en general se inicia con la pérdida de la cola poli A mediante desadenilación. En eucariotas existen varios complejos que participan del proceso: PARN2-PARN3 iniciaría la desadenilación, el complejo CAF1-CCR4-NOT, cuyos componentes se localizan en PB, continúa el proceso. Posteriormente el proceso continúa mediante degradación nucleolítica en ambos extremos (Fig.2):

- la degradación 3’ $\rightarrow$ 5' es catalizada por el exosoma y por el complejo SKI

- la degradación 5' $\rightarrow$ 3' requiere la previa remoción del cap por la enzima de decapping Dcp2 y su coactivador Dcp1, luego la degradación continúa por acción de la enzima Xrn1. Varias proteína son capaces de estimular el decapping (Eulalio et al., 2007a). Este grupo de enzimas se localizan en los PB.

Existen varias evidencias de que la degradación de ARNm ocurre en PB:

- el ensamblado de los PB es dependiente de ARN, ya que el tratamiento con ARNasa o la inhibición de la transcripción con actinomicina D provoca la pérdida de los PB

- cuando se bloquea el decaimiento de mensajeros en los primeros pasos (falta de desadenilasa CCR4) los PB desaparecen, en cambio, el bloqueo en pasos tardíos (falta de Xrn1 o Dcp1) provoca un aumento en el tamaño y número de PB

- los intermediarios del decaimiento de mensajeros se encuentran en PB

Por lo tanto se puede concluir que la degradación de mensajeros ocurre en PB y que depende la existencia de mRNP destinados a degradación (Andrei et al., 2005; Brengues et al., 2005; Cougot et al., 2004; Sheth and Parker, 2003). 
Muchos de los componentes de PB no sólo están restringidos a estas estructuras sino que también se encuentran distribuidos por el citoplasma en forma difusa, se cree que existe un intercambio entre el pool citoplasmático y los PB, incluso la degradación de ARNm podría comenzar en el citoplasma y continuar en los PB. Sin embargo la alta concentración de factores en los PB aumenta la probabilidad de que se produzca la degradación de ARNm.

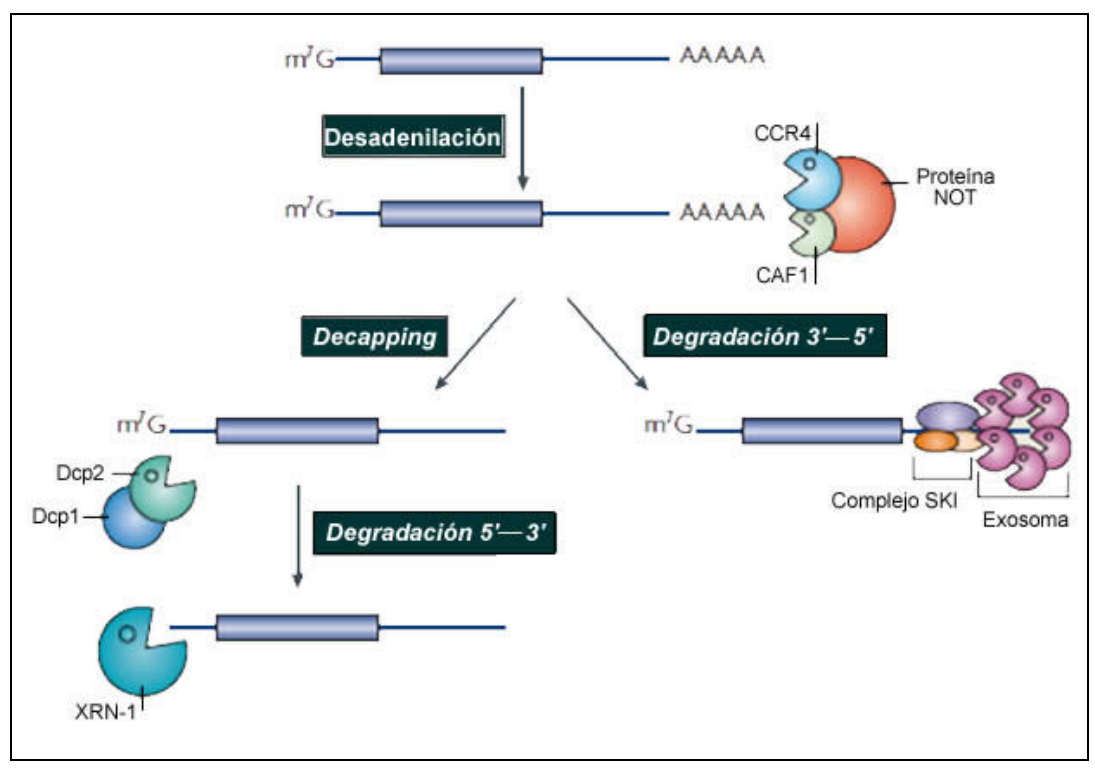

Figura 2. Mecanismo de degradación de ARNm. Luego de la desadenilación el ARNm puede sufrir decapping y decaimiento $5^{\prime} \rightarrow 3^{\prime}$ (izquierda) o decaimiento $3^{\prime} \rightarrow 5^{\prime}$ mediado por exosoma (derecha). (Modificado de Eulalio et al., 2007).

\section{PB y control de calidad del ARNm}

Los mecanismos de control de la calidad de mensajeros han evolucionado en eucariotas de forma tal que sólo se traduzcan ARNm completamente procesados y sin errores. Uno de los mecanismos de control de calidad es NMD (non-sense mediated $m R N A$ decay), que reconoce y degrada ARNm que poseen un codón de terminación temprano. Esto impide la síntesis de proteínas truncadas potencialmente tóxicas para la célula. La detección de un codón de terminación prematuro por NMD genera el ensamblado de un complejo de vigilancia sobre el ARNm compuesto por UPF1, UPF2 y UPF3, y cuatro proteínas adicionales (SMG1 y SMG5-7)(Amrani et al., 2006; Conti 
and Izaurralde, 2005; Lejeune and Maquat, 2005). Una vez ensamblado el complejo de vigilancia, son reclutadas enzimas involucradas en el decaimiento de mensajeros (Dcp2, Xrn1, o exosomas).

En células humanas los componentes del mecanismo NMD se ubican en PB, se desconoce el mecanismo de reclutamiento.

\section{PB y silenciamiento génico}

Existen dos tipos de ARNm pequeño no codificante que se encargan de regular la expresión génica post-transcripción, siARN y miARN. A pesar de que el mecanismo de silenciamiento es diferente, en ambos casos participan las proteínas Argonauta y el complejo RISC (RNA induced silencing complex). Los siARN se aparean por complementariedad a sus blancos y promueven su clivaje y degradación. Las proteínas Argonauta producen un clivaje endonucleolítico y el ARNm resultante es degradado por la maquinaria de decaimiento $3^{\prime} \rightarrow 5^{\prime}$ y $5^{\prime} \rightarrow 3^{\prime}$.

La mayoría de los miARN en células de mamífero son sólo parcialmente complementarios a sus blanco, y actúan promoviendo el decaimiento o la represión traduccional. En este caso el decaimiento no se genera por rotura endonucleolítica mediada por Argonauta sino dirigiendo el ARNm hacia la maquinaria de degradación y acelerando su desadenilación. Para que eso se produzca es necesaria la presencia de Argonauta, y de otros componentes de PB: GW182, CCR4-CAF1-NOT1, Dcp2, Dcp1 y Xrn1.

\subsubsection{El (ciclo) del ARNm}

Hay muchos puntos aún no resueltos en lo que respecta al movimiento del ARNm y el pasaje de un estado traduccionalmente activo hacia uno inactivo, y viceversa. El modelo más actual sugiere un movimiento entre polisomas, PB y SG (Balagopal and Parker, 2009).

Los ARNm traduccionalmente activos pueden interaccionar, en respuesta a fallas en el inicio de la traducción o por reclutamiento específico, con factores que reprimen la traducción (Dhh1, Pat 1, Lsm1-7); estos factores serían reemplazados por otros diferentes y se produciría la eliminación del cap y la consecuente degradación del 
ARNm (Balagopal and Parker, 2009) o su acumulación en PB. Posteriormente los PB podrían remodelarse nuevamente (cambiar sus factores) y estos mRNP regresar a polisomas. A su vez parece ser que los PB intercambian componentes con los SG (Fig.3). Por lo tanto, la acumulación de mRNP en gránulos sería una forma mediante la cuál las células regulan una tasa de traducción correcta para las distintas condiciones (fases del ciclo celular, períodos del desarrollo, ciclos circadianos, etc.).

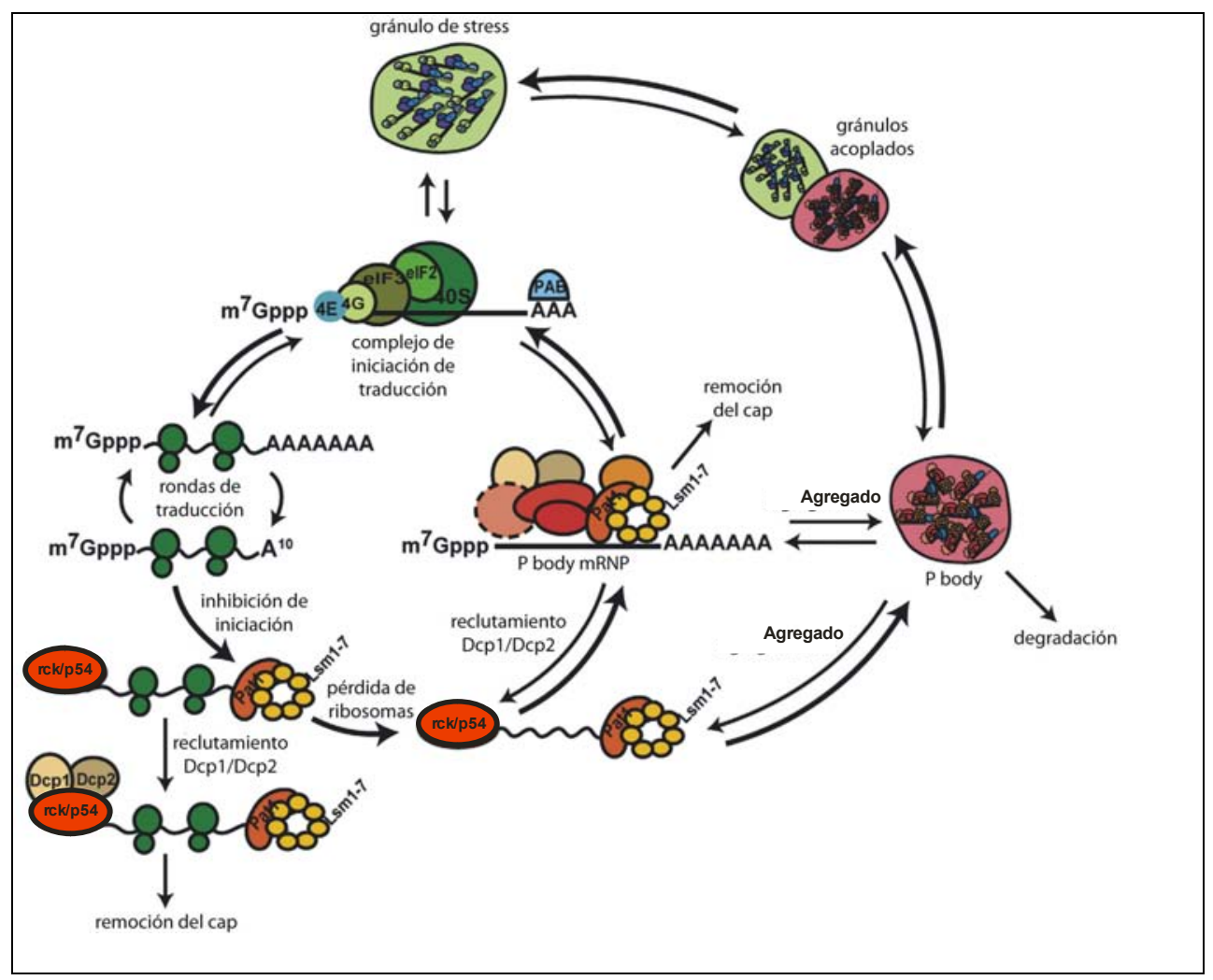

Figura 3. El ciclo del ARNm. El ARNm puede encontrarse en el citoplasma en al menos tres formas: polisomas, PB y SG. El reclutamiento de represores traduccionales, como Dhh1 y Pat 1, facilita el movimiento del ARNm a un estado inactivo traduccionalmente. Posteriormente hay reclutamiento de factores de remoción del cap, eliminación del cap y consecuentemente, degradación. Los ARNm acoplados a los factores de remoción del cap pueden ser degradados, acumulados en PB o vueltos a polisomas. Las condiciones limitantes para el inicio de la traducción pueden ser superadas mediante la agregación en SG, donde la concentración local de componentes de la maquinaria de traducción es alta. (Modificado de Buchan and Parker 2009). 


\subsection{Drosophila melanogaster}

El género Drosophila tiene como significado "amante del rocío" y la especie melanogaster hace referencia a su "abdomen de coloración negra". Esta especie pertenece al orden Díptera y a la familia Drosophilidae, es un insecto holometábolo de hábitat cosmopolita, se caracteriza por consumir alimentos con altos contenidos de ácido acético.

Drosophila melanogaster $(\mathrm{Dm})$ lleva más de un siglo siendo empleada como organismo modelo para todo tipo de estudios genéticos ya que presenta una serie de características que la hacen especialmente interesante, entre ellas: enorme facilidad de cultivo y manipulación en el laboratorio, tiempo de generación relativamente corto y de $25^{\circ} \mathrm{C}$, gran descendencia en cada generación, disponibilidad de la secuencia completa de su genoma, ampliamente estudiada en todos sus estadios de desarrollo.

Muchas de las rutas que dirigen procesos básicos del desarrollo de vertebrados e invertebrados han permanecido intactas en ambos organismos a lo largo de la evolución, esto hace posible una aplicación casi inmediata a los sistemas vertebrados de todo aquello que se descubra en Drosophila. Por lo que resulta un excelente organismo eucariota de estudio.

Por otro lado, se ha comprobado experimentalmente que muchos genes de Drosophila pueden reemplazar funcionalmente a sus equivalentes en otros organismos. La mitad de las proteínas de Drosophila tienen similitudes importantes con proteínas de mamíferos. El $61 \%$ de los genes humanos responsables de enfermedades hereditarias y el 68\% responsables de cáncer tienen un gen equivalente en Drosophila.

Particularmente en esta tesis se utilizarán células S2 de Drosophila melanogaster como modelo principal de estudio. Esta línea celular fue derivada de un cultivo primario de fase tardía (20-24 horas) de embriones de Drosophila melanogaster (Schneider, 1972). Muchas de las características de la línea celular S2 sugieren que deriva de un linaje similar a los macrófagos. Las células crecen a temperatura ambiente $\left(22-28^{\circ} \mathrm{C}\right)$, sin $\mathrm{CO}_{2}$, de forma semi-adherente en monocapa en frascos de cultivo de tejidos. 


\subsection{Antecedentes y objetivos}

La proteómica es el estudio, a gran escala, de las funciones celulares al nivel de la química de proteínas. Se estudia el producto final de la expresión genética (el proteoma), es una disciplina que combina viejas técnicas bioquímicas y nuevas tecnologías, lo que permite la aplicación simultánea a un gran número de muestras. Conceptualmente, el sistema proteómico más simple consiste en la identificación de los componentes proteicos de la célula o de una organela en determinadas condiciones (Mann et al., 2001; Ong et al., 2003). La proteómica funcional se encarga de la localización y distribución subcelular de proteínas y de las interacciones que se producen entre las proteínas y otras moléculas con el fin de determinar su función.

En nuestro laboratorio se ha estudiado la genética y genómica de Drosophila melanogaster durante más de diez años, con énfasis en los procesos relacionados con la embriogénesis y la muerte celular. Los estudios de los mecanismos de la segmentación en el embrión de Drosophila derivaron rápidamente en el estudio del control de la traducción de genes maternos que controlan la polaridad anteriorposterior del embrión combinando genética clásica, biología molecular y bioquímica (Niessing et al., 1999; Niessing et al., 2000; Rivera-Pomar et al., 1996). A partir de estos estudios se determinó el rol de los factores de iniciación de la traducción en otros procesos celulares de relevancia durante el desarrollo embrionario como son el control de la proliferación y apoptosis (Hernandez et al., 2004a; Hernandez et al., 2004b; Vazquez-Pianzola et al., 2007). Desde el punto de vista genómico se realizó un barrido in sílico del genoma de Drosophila para determinar si existía redundancia funcional de los genes involucrados en la iniciación de la traducción y así se determinó el rol primario del factor de iniciación eIF4E en el desarrollo embrionario, la proliferación celular y la apoptosis (Hernandez et al., 2005), y de la redundancia de función de las isoformas del factor de iniciación eIF4E en los mismos procesos. A partir de estos estudios se profundizó el estudio del mecanismo de traducción de genes proapoptóticos y de las proteínas involucradas en el reconocimiento de los ARNm (Vazquez-Pianzola et al., 2005). En el área de proteómica el laboratorio ha estudiado la composición de complejos ribonucleoproteicos en $\mathrm{Dm}$ usando un método de etiquetado de ARN para la purificación de complejos ribonucleoproteicos asociados a 
genes proapoptoticos, separando los componentes de los mismos por 1D-PAGE y estableciendo la identidad de la mayoría de los componentes por LC-MS-MS y MALDI-TOF-MS. Como los ARNm de los genes proapoptoticos están regulados por miARN y como el factor de iniciación eIF4E fue identificado en nuestro laboratorio como parte de $\mathrm{PB}$, otra línea de investigación, directamente relacionada con este proyecto, involucra el análisis de los componentes de los PB en células humanas y en células de Drosophila en cultivo. Así es como identificamos que el factor eIF4E es el único componente de la maquinaria de síntesis proteica presente en PB. Allí interacciona con el represor de la traducción eIF4E-T y con la helicasa p54/rck, como hemos podido comprobar in vivo (Andrei et al., 2005). Estos estudios han generado una cantidad de nuevas preguntas e hipótesis que han derivado en la presente tesis.

El objetivo general de esta tesis es estudiar la interacción de proteínas que integran los complejos ribonucleoproteicos responsables del metabolismo de ARN mensajeros en cuerpos de procesamiento citoplasmáticos. El estudio se enfocará a la participación del factor de inicio de la traducción eucariota eIF4E en procesos de regulación de la expresión génica vinculados al metabolismo del ARNm.

Los objetivos específicos consisten en estudiar la función no canónica de eIF4E, una proteína proliferativa por excelencia, vinculada a la translocación y el silenciamiento de ARNm hacia los PB utilizando a Drosophila melanogaster como modelo de estudio. Nos interesa:

1.- Detallar la composición de los PB en células S2 de Drosophila melanogaster.

2.- Determinar si la unión de eIF4E al cap (residuo 7-metil guanosina) de los ARNm es condición esencial para su transporte hacia PB o para protegerlos de la degradación en los mismos.

3.- Identificar qué proteínas interactúan directa o indirectamente con eIF4E en los complejos de silenciamiento, estudiar las redes de interacciones y su función regulatoria en la expresión génica en células $\mathrm{S} 2$ de $D m$ en cultivo. 


\section{Resultados}




\section{Capítulo 1.}

\subsection{Caracterización de los gránulos citoplasmáticos.}

La existencia de gránulos citoplasmáticos que contienen ARNm traduccionalmente reprimido en las células germinales, los embriones y las neuronas se conoce desde hace mucho tiempo. Estos agregados macromoleculares se denominan gránulos de ARN, y el término define un amplio espectro de entidades, que van desde gránulos de ARN de transporte neuronal hasta estructuras específicas para el almacenamiento de ARNm materno. Dos tipos de gránulos adicionales se han descubierto recientemente, llamados "gránulos de procesamiento" (PB) y "gránulos de estrés" (SG). Los PB fueron inicialmente descritos como agregados citoplásmicos que albergan la maquinaria de la degradación del ARN (Andrei et al., 2005; Bashkirov et al., 1997; Ingelfinger et al., 2002; Sheth and Parker, 2003). Además de las numerosas vías de silenciamiento que operan en condiciones normales, los estímulos de estrés desencadenan varios caminos que conducen a un silenciamiento de traducción global, $\mathrm{y}$ esto se correlaciona con la formación de una especie distinta de focos de silenciamiento del ARNm: los SG. La formación de PB y SG ha sido ampliamente debatida recientemente (Anderson and Kedersha, 2008; Buchan and Parker, 2009;

Franks and Lykke-Andersen, 2008), estando ambas estructuras estrechamente relacionadas; incluso se propone que hay un intercambio de componentes entre ellos (Anderson and Kedersha, 2008; Buchan et al., 2008)

\subsubsection{Me31B es un componente de PB de una subpoblación de células S2}

La proteína Me31B es una helicasa de la familia de $D E A D$ box, que se caracteriza por presentar el motivo conservado Asp-Glu-Ala-Asp (DEAD). Participa en el proceso de degradación de ARNm y se expresa en estadíos tempranos del desarrollo (está codificada por un gen materno) en Drosophila melanogaster. Se ha sugerido que Me31B media el silenciamiento de ARN específicos durante su transporte en la ovogénesis, sugiriendo que el transporte de ARN y el control de la traducción están vinculados a través de la formación mRNP (Nakamura et al., 2001). 
Los ortólogos de Me31B en otras especies se encuentran en las células formando gránulos citoplasmáticos; rck/p54 en humanos (Andrei et al., 2005; Cougot et al., 2004), CGH-1 en C. elegans (Navarro et al., 2001), y Dhh1 en S. cerevisiae, (Coller and Parker, 2005; Sheth and Parker, 2003).

Se encontró que Me31B también se acumula en gránulos distribuidos por todo el citoplasma en células S2 de Dm (Fig. 4) en concordancia con lo encontrado por Nakamura y col., y Eulalio y col. (Eulalio et al., 2007b; Nakamura et al., 2004). Resultados previos habían encontrado a Me31B en gránulos en ovarios de Drosophila (Lin et al., 2008) y en células neuronales (Hillebrand et al., 2007).

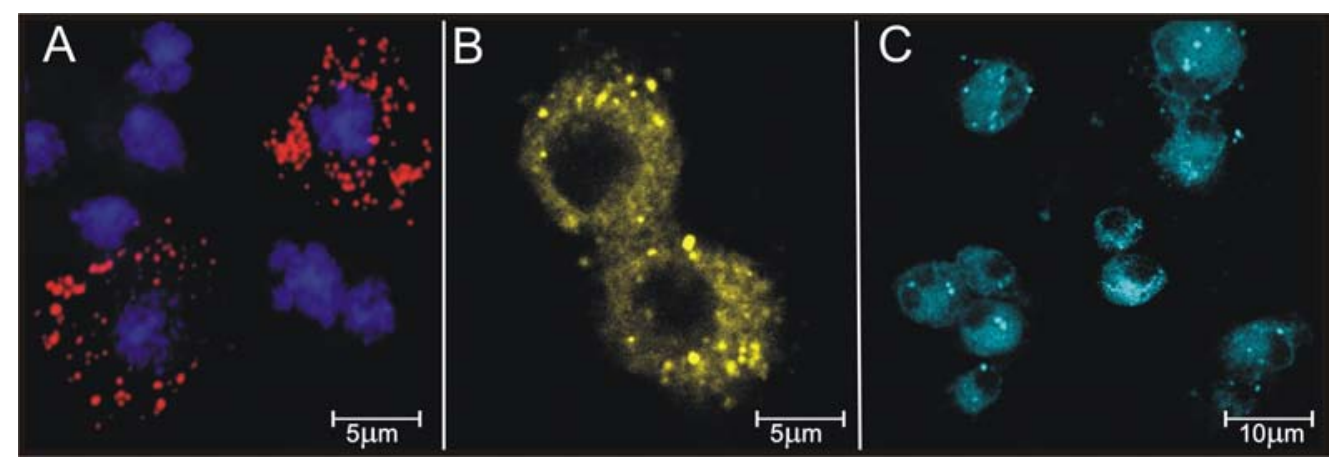

Figura 4. Células S2 de Drosophila melanogaster. A: Me31B detectada mediante inmuno histoquímica (Anti-rck-p54, Cy3,rojo), en color azul núcleos teñidos con DAPI. B: transfección de células S2 con YFP-Me31B. C: transfección de células S2 con CFP-Me31B.

Es importante destacar que sólo algunas células presentan dichos gránulos, mientras que otro grupo de células parece no expresar la proteína. Debido a que la línea celular Schneider 2 está compuesta por una población de células en diferentes estadios, y como Me31B es un gen materno puede ser que sólo se exprese en algunas células específicas de linaje materno.

La figura 5 muestra la localización de rck/p54 en gránulos citoplasmáticos en células HeLa, se puede observar la tinción con anticuerpo específico y las transfecciones con las proteínas de fusión fluorescentes CFP-rck/p54 y YFP-rck-p54. En este caso encontramos a la proteína en todas las células, a diferencia de lo encontrado en células $\mathrm{S} 2$, donde se reconoce una subpoblación de ellas. 


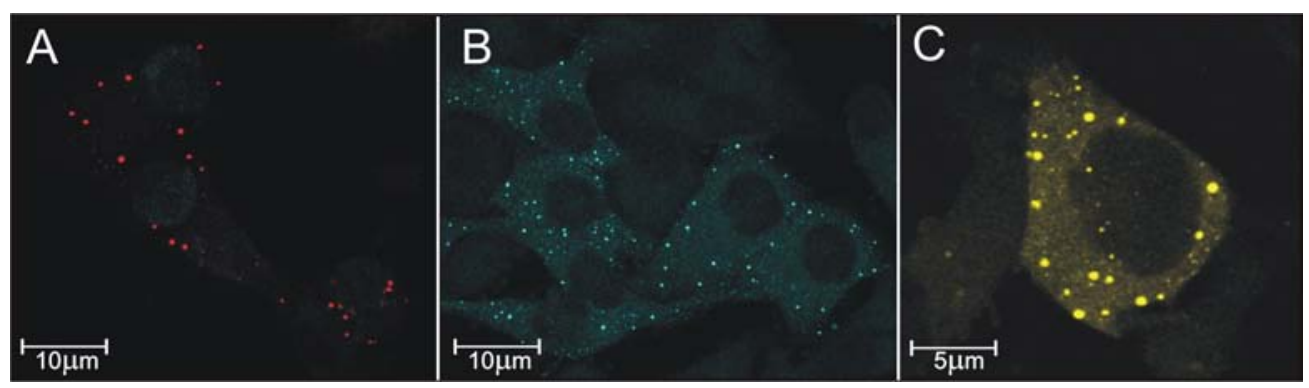

Figura 5. Localización de rck/p54 en células HeLa. A: inmuno histoquímica con anti rck-p54 (rojo, Cy3), se observa la proteína endógena en gránulos, en azul se distinguen los núcleos (por transfección con la proteína nuclear p53, Cy2). Se muestra la ubicación en gránulos citoplasmáticos de CFPrck/p54 (B) y de YFP-rck/p54 (C).

Para establecer el tipo de gránulos donde encontramos a Me31B se realizó inmuno histoquímica de las proteínas GW182 (componente principal de PB) y TIA-1 (componente principal de SG). Previamente, realizamos un control en el cuál evaluamos si estos dos marcadores de gránulos son específicos de cada tipo de estuctura. Para ello se realizó inmuno histoquímica sobre un preparado de células S2 fijado. En la figura 6 se muestran los resultados, en panel superior de la figura se observa que GW182 se acumula en gránulos citoplasmáticos (PB), mientras que TIA1 no lo hace. En el panel inferior de la figura, las células fueron estresadas con arsenito de sodio $(1 \mathrm{mM})$ por 30min previamente a la fijación; podemos observar, que TIA-1 se acumula en gránulos citoplasmáticos (SG), mientras que GW182 no se encuentra en estos gránulos. Por lo tano, estas dos proteínas son buenos marcadores diferenciales de estas estructuras y serán utilizadas a lo largo de esta tesis con dicha finalidad.

En la figura 7 puede observarse que la proteína Me31B co-localiza con GW182 en algunos gránulos (aprox. 26\%). Esto indicaría, que ambas proteínas se encuentran en los mismos tipos de gránulos y éstos serían PB. Por otro lado, se encontró la existencia de gránulos de Me31B donde no se encuentra GW182 (34\%), y asimismo se encontró que en un $40 \%$ de los gránulos sólo está presente GW182. La existencia de estos dos tipos de gránulos puede explicarse de diferentes formas: estos gránulos pueden ser estados intermediarios, que van reclutando diferentes componentes hasta que convergen a la formación de PB. Por otra parte, puede tratarse de otros tipos de gránulos desconocidos aún no caracterizados. Finalmente la existencia de estos gránulos puede deberse a la gran dinámica de los $\mathrm{PB}$, los cuales pueden verse por 
momentos desprovistos de algunos de sus componentes, o que estén presentes en concentraciones bajas no detectadas.

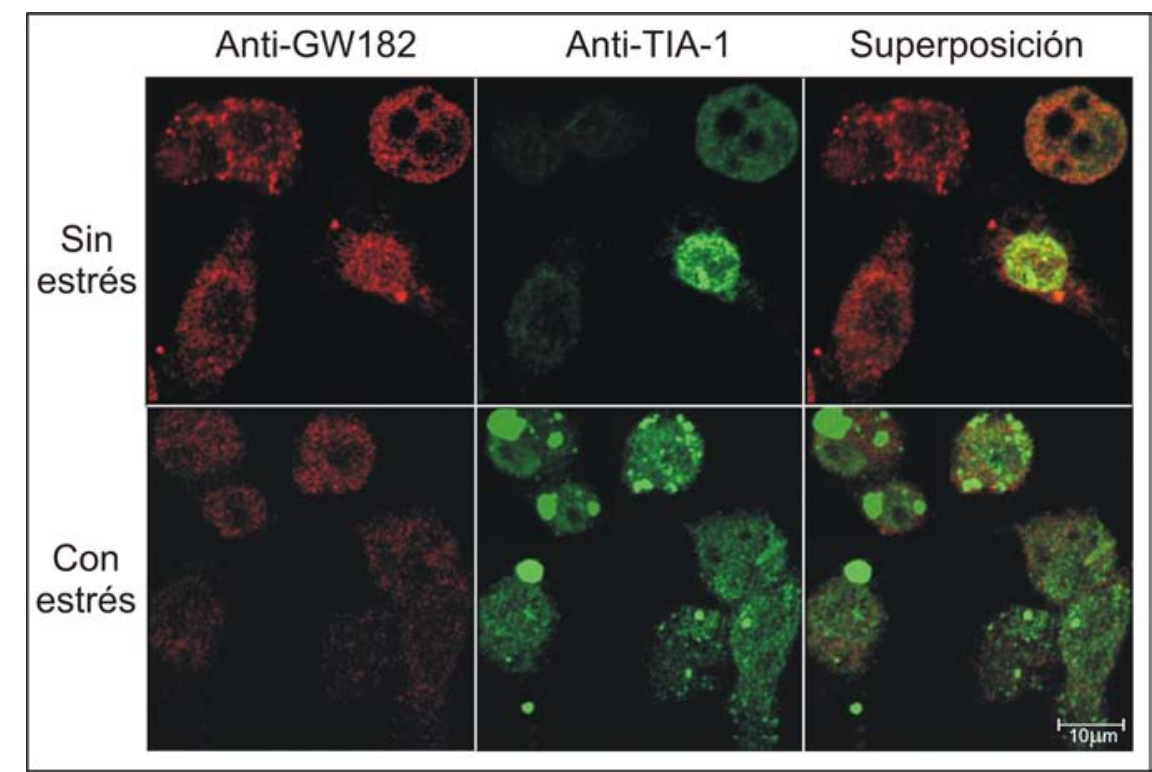

Figura 6. Se muestra la inmuno histoquímica con anti-GW182 y anti-TIA-1, donde se observa claramente que GW182 se ubica en gránulos citoplasmáticos constitutivos (PB), y TIA-1 en gránulos inducidos por estrés (SG).

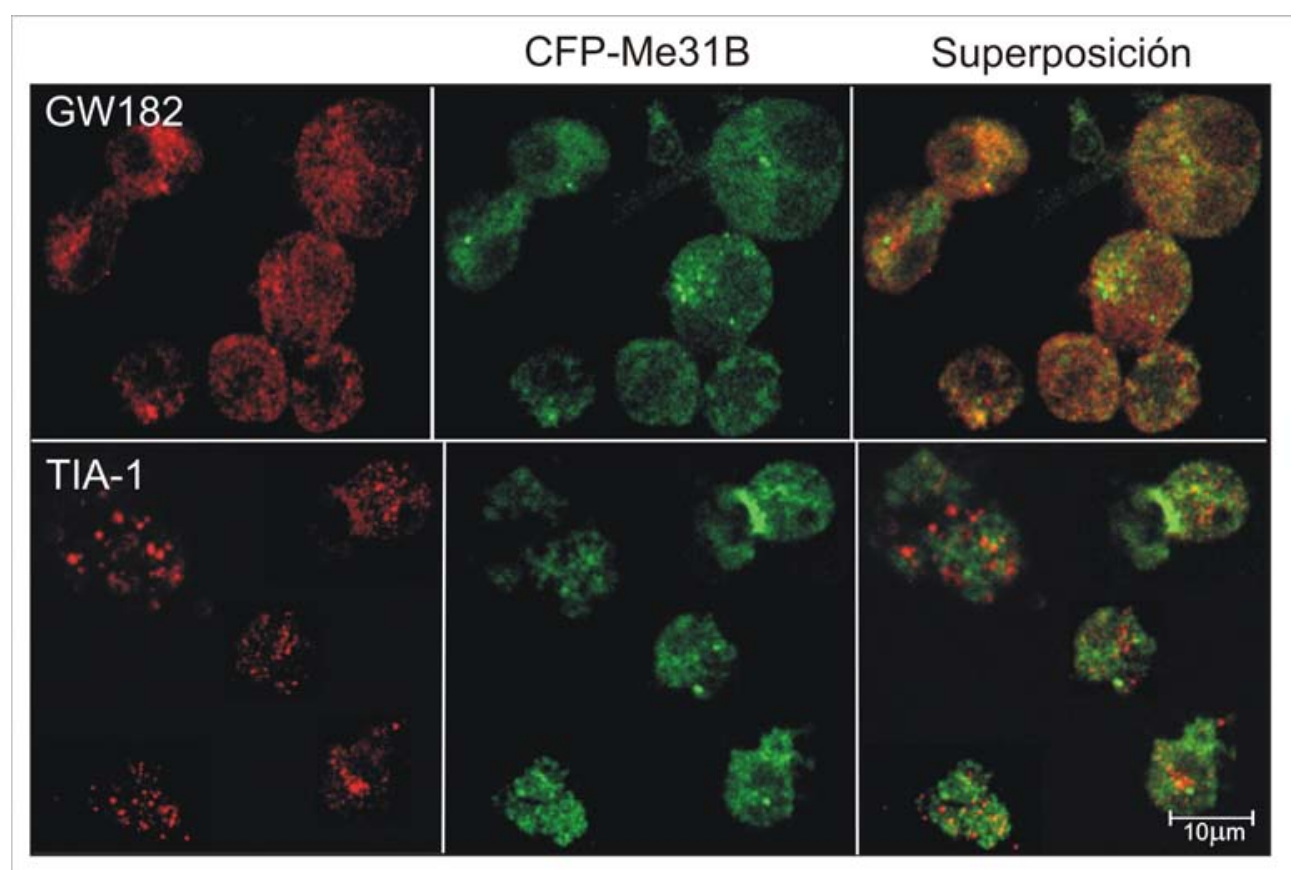

Figura 7. Células $\mathrm{S} 2$ de $\mathrm{Dm}$ transfectadas con la proteína de fusión CFP-Me31B. Inmuno histoquímica para GW182 (panel superior) y para TIA-1 (panel inferior). 
En el panel inferior de la figura 7 se observa que no existe co-localización entre las proteínas Me31B y TIA-1 en células S2 de Dm estresadas mediante tratamiento con arsenito de sodio, por lo tanto podemos inferir que Me31B no se encuentra en gránulos de estrés en dichas células. Sin embargo, existe evidencia de que el ortólogo rck-p54 se encuentra en SG en células HeLa estresadas con arsenito (Wilczynska et al., 2005).

\subsubsection{Lsm-1 se encuentra en PB y no en SG en células de Dm.}

La proteína Lsm-1 se conoció en $S$. cerevisiae como uno de los componentes de una familia que posee un motivo de secuencia común $(\mathrm{Sm})$ de siete aminoácidos altamente conservados, incrustados en un patrón característico de aminoácidos hidrofóbicos e hidrofílicos que se unen al ARN. Todos los miembros de la familia, que han sido bien caracterizados a nivel bioquímico, oligomerizan para formar un heptámero de forma anular que se une al ARN con una preferencia para la oligo [U] (Kambach et al., 1999). Se conocieron, en primera instancia, como proteínas de unión al ARN nuclear pequeño U6, participando en el splicing del pre-ARNm. (Cooper et al., 1995; Hermann et al., 1995; Mayes et al., 1999; Pannone et al., 1998; Salgado-Garrido et al., 1999; Seraphin, 1995; Stevens and Abelson, 1999). Estudios posteriores demostraron que las proteínas Lsm pueden promover el decapping del ARNm por medio de su interacción con el ARNm y con la maquinaria de decapping (enzimas Dcps). Por otro lado, se estableció que el complejo Lsm que funciona en la degradación del ARNm (Lsm1-7) parece ser distinto de los complejos Lsm asociados a U6 (Lsm2-8). Esto indica que las

proteínas Lsm forman complejos específicos que afectan diferentes aspectos del metabolismo del ARNm (Tharun et al., 2000). Posteriormente, ensayos de co-inmuno precipitación permitieron adelantar que en el remodelamiento de RNP existe un paso crucial que define el pasaje desde un estado activo a uno inactivo, y comprende la pérdida de la unión del mensajero con $\mathrm{PABP}$, y los factores de inicio y la asociación con el complejo Lsm1-7 y con las enzimas de decapping. Por lo tanto, la función de las proteínas Lsm1-7, sería la de participar en el remodelamiento de mRNP desde un estado activo a un estado degradativo (Tharun and Parker, 2001). 
Estudios previos demostraron la localización de la proteína en gránulos citoplasmáticos en S. cerevisiae (Sheth and Parker, 2003) cuyo número es bajo en condiciones normales, pero se incrementa en condiciones de estrés por déficit de glucosa (Teixeira and Parker, 2007).

Aquí mostramos que la proteína Lsm-1 se acumula en gránulos citoplasmáticos en células S2 de Drosophila melanogaster (Fig.8A y B) en concordancia con lo encontrado por Eulalio y col. (Eulalio et al., 2007b). A diferencia de lo observado en levaduras el número de gránulos es abundante en condiciones fisiológicas.

También se evaluó la presencia de hLsm-1 en células HeLa, se vio su acumulación en gránulos citoplasmáticos (Fig. 8C), abundantes en condiciones fisiologicas. Ingelfinger y col. habían encontrado anteriormente que la proteína hLsm-1 forma heptámeros que participan en la degradación de los mensajeros, y mostraron que se acumula en gránulos citoplasmáticos junto con las enzimas de decapping (Ingelfinger et al., 2002).

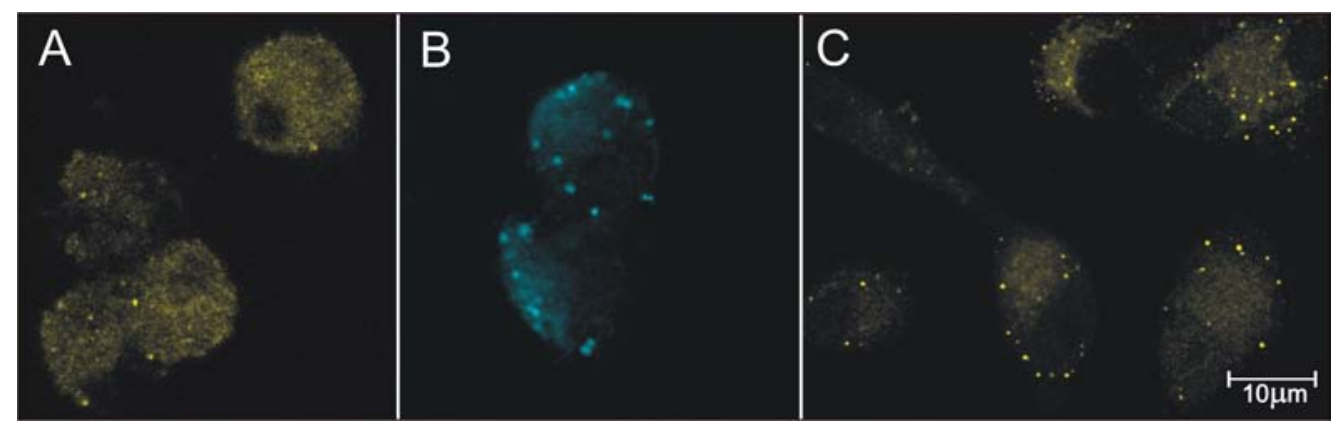

Figura 8. Localización de Lsm-1 en células S2 (A: YFP-Lsm-1, B: CFP-Lsm-1) y en células HeLa (C: YFP-hLsm-1) por medio de transfección de células con proteínas de fusión fluorescentes.

Para caracterizar el tipo de gránulo donde se encuentra a Lsm-1 se realizaron transfecciones de células S2 con la proteína de fusión CFP-Lsm-1, y posteriormente se realizó inmuno histoquímica para las proteínas GW182 y TIA-1 (Fig. 9). 


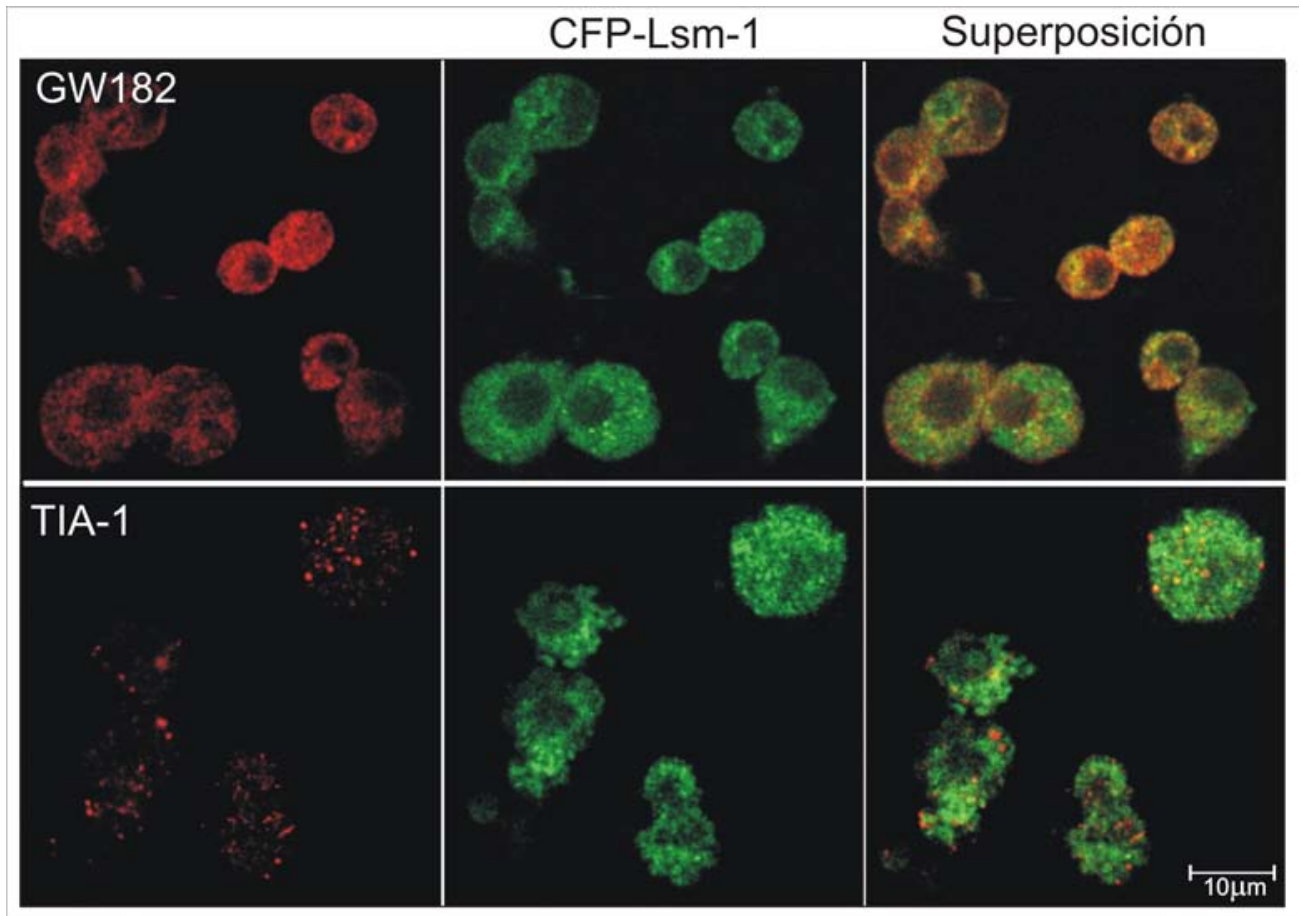

Figura 9. Lsm-1 co-localiza con GW182 en gránulos citoplasmáticos en células $\mathrm{S} 2$ de Dm (panel superior). En el panel inferior se muestra la tinción para TIA-1 en células previamente estresadas, no se observa co-localización con Lsm-1.

Se encontró que Lsm-1 se encuentra en un 33 \% de los gránulos analizados colocalizando con GW182 (Fig. 9 panel superior). En un 36\% de los gránulos se observa sólo a Lsm-1 y en un 31\% solamente se encuentra presente GW182. Por otro lado, se estableció que no existe co-localización entre las proteínas Lsm-1 y TIA-1 en SG en células S2 tratadas con arsenito de sodio (Fig. 9 panel inferior).

Se puede concluir por lo tanto que Lsm-1 se encuentra presente en PB y ausente en SG en células S2 de Dm.

\subsection{3 eIF4E es un componente que participa en la traducción de mensajeros y en su almacenamiento y/o degradación en PB.}

La proteína eIF4E es ampliamente conocida y muy estudiada por su función canónica como factor del inicio de la traducción eucariota. Integra un complejo proteico que reconoce el residuo 7-metil guanosina (cap) ubicado en el extremo 5' del ARNm porque recluta, a través de la proteína adaptadora eIF4G, una serie de factores 
cuya función final es la de posibilitar la unión de la subunidad menor del ribosoma al ARNm para llevar a cabo la síntesis proteica. Además posee una función adicional relacionada con el proceso de degradación de ARNm. Aún no se conoce el mecanismo mediante el cuál un ARNm pasa de un estado en el que se traduce a un estado inactivo, pero si puede pensarse que eIF4E participa activamente en el proceso, ya que es la única proteína de unión a ARNm que está presente en los mRNP activos y en los mRNP inactivos. Por lo tanto podría inferirse que es una candidata a ser la encargada, junto a otras proteínas, de participar del transporte del ARNm hacia PB. Fue encontrada en PB en diferentes organismos.

La estructura 3D de la proteína eIF4E está filogenéticamente conservada desde levaduras hasta humanos. Las estructuras observadas mediante rayos $\mathrm{X}$ en ratón y levaduras del co-cristal de eIF4E truncada con el análogo del cap 7mGDP, muestran una estructura $\alpha / \beta, 8$ cadenas $\beta$ antiparalelas forman una hoja $\beta$. La estructura posee en su superficie cóncava una estrecha ranura hidrofóbica donde se une el cap (Sonenberg and Dever, 2003). Estudios de comparación de secuencia de las proteínas eIF4E eucariotas demostraron que el extremo $\mathrm{N}$ - terminal de la proteína es variable y no es requerido para la unión al cap del mensajero. En cambio, el extremo C-terminal está bastante conservado entre diferentes organismos eucariotas, se conservan alrededor de 182 aminoácidos (Marcotrigiano et al., 1997).

Estudios posteriores mostraron la estructura del cristal de eIF4E humana completa unida a $7 \mathrm{mGpppA}$ (su ligando real). En este, la adenosina del ligando interacciona con los residuos T205 y T211 formando puentes de hidrógeno y con el residuo S207 por interacciones de Van der Waals (Tomoo et al., 2002). El cap se ubica entre las dos cadenas laterales de los residuos W56 y W102 (Fig.10). Los residuos S209 y K159 forman un puente salino retráctil que estabiliza la unión al cap del mensajero. Para que este puente se forme es necesario que la S209 esté fosforilada, de hecho la fosforilación de dicho aminoácido es un mecanismo de regulación muy importante (Whalen et al., 1996). 


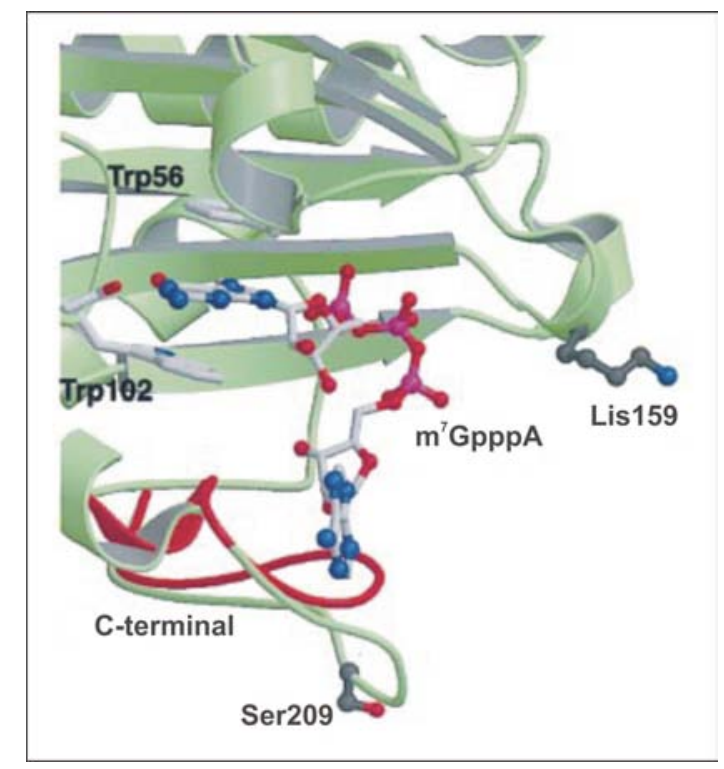

Figura 10. Esquema representativo de la estructura del dominio C-terminal de eIF4E humana cuando se encuentra unida al m7pppA. Se marcaron los aminoácidos más relevantes de dicha unión.

En mamíferos se conocen tres isoformas de esta proteína, eIF4E-1, 4E-HP, y eIF4E3 (Joshi et al., 2004); en plantas también existen tres isoformas, eIF(iso)4E (Browning, 1996), en cambio en C. elegans existen al menos cinco (Keiper et al., 2000), en Zebrafish, en Xenopus y en S. pombe existen dos (Robalino et al., 2004) y al parecer existe sólo una en $S$.cerevisiae (Altmann et al., 1987). En Dm existen siete genes para eIF4E, los cuáles codifican ocho polipéptidos diferentes eIF4E-1, eIF4E-2, eIF4E-3, eIF4E-4, eIF4E-5, eIF4E-6, eIF4E-7, y d4E-HP (antiguamente eIF4E-8) (Hernandez et al., 2005). Un mismo gen codifica, por splicing alternativo, las isoformas eIF4E-1 y eIF4E-2, mientras que las otras isoformas tienen cada una un gen propio (Hernandez and Sierra, 1995). Todas las isoformas, excepto d4E-HP, poseen el residuo de lisina que participa en la formación del puente salino para la unión al cap previamente mencionado (K159 en humanos). Contrariamente, ni la isoforma 6 ni la 3 poseen el residuo fosforilable de serina que participa en dicha unión (S251 en eIF4E-1, en humanos S209). Estudios in vitro demostraron que todas las isoformas son capaces de unirse al cap, sin embargo, eIF4E-6 y 8 lo hacen con baja afinidad. Por otro lado ensayos de doble híbrido demostraron que eIF4E-1, 2 y 4 interaccionan fuertemente con eIF4G y 4E-BP; eIF4E-3, 5 y 7 lo hacen más débilmente mientras que eIF4E-6 y 8 no lo hacen (por lo menos no in vitro por doble híbrido). Estudios in vivo en levaduras 
demostraron que al menos 5 de las isoformas; eIF4E-1, eIF4E-2, eIF4E-3, eIF4E-4, y eIF4E-7; son funcionales in vivo (Hernandez et al., 2005).

En la figura 11 se muestra la localización de eIF4E en gránulos citoplasmáticos tanto en células de $\mathrm{Dm}$ como en células HeLa, por medio de inmuno histoquímica con un anticuerpo específico y por transfección con proteínas de fusión fluorescentes.

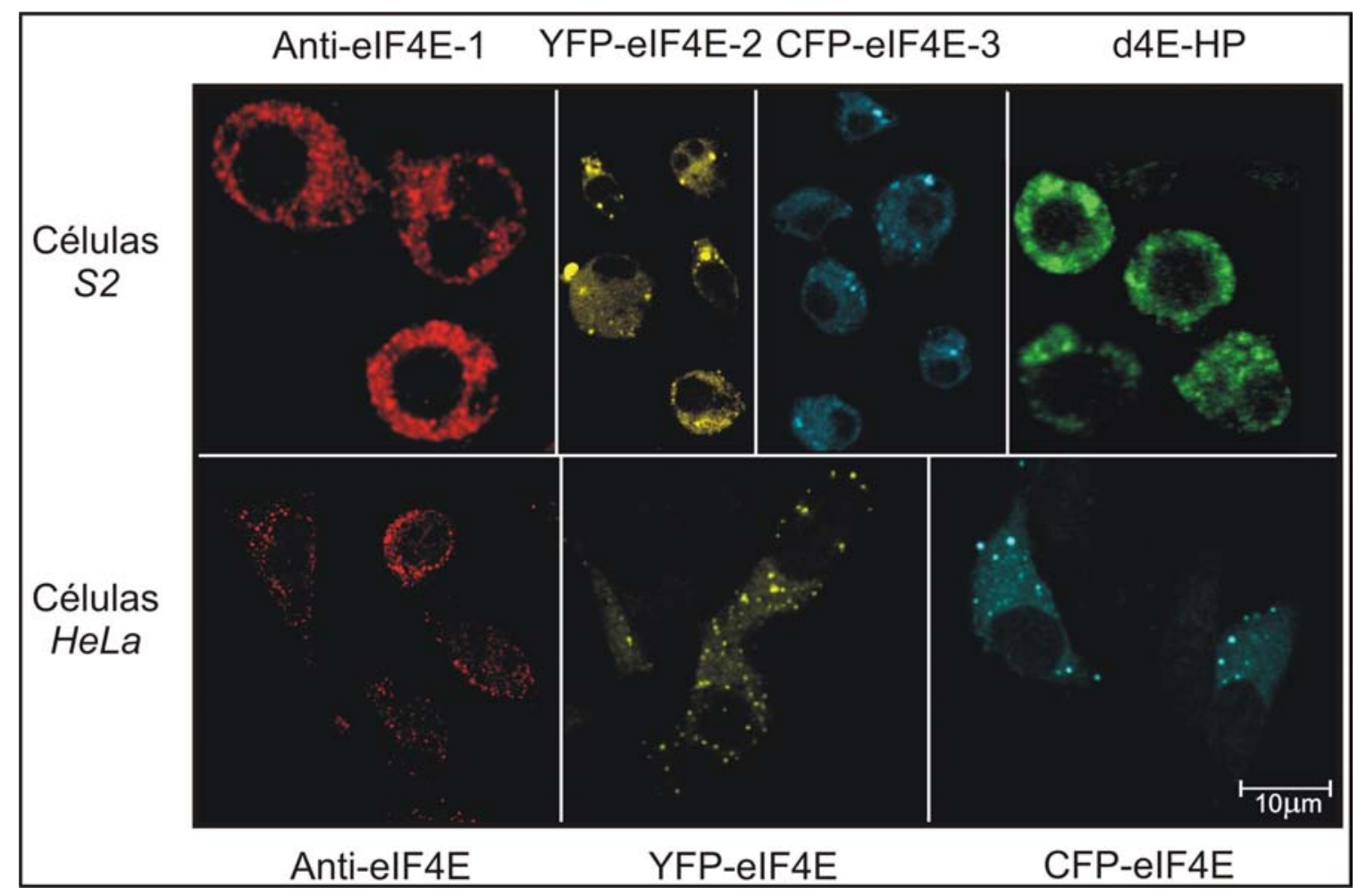

Figura 11. Localización de eIF4E en gránulos citoplasmáticos en células $\mathrm{S} 2$ (panel superior). Se observa la acumulación en gránulos de las isoformas eIF4E-1, eIF4E-2, eIF4E-3 y d4E-HP. En el panel inferior se observa a eIF4E-1 en gránulos citoplasmáticos en células HeLa.

Demostramos que las isoformas eIF4E-1, eIF4E-2, eIF4E-3, y d4E-HP se encuentran en gránulos citoplasmáticos. Es importante destacar el caso de eIF4E-3, que a pesar de carecer del residuo de S251, que como se mencionó anteriormente, es crítico para la función de eIF4E-1 en Dm, es encontrada en gránulos. Esto indicaría que podría igualmente cumplir una función en la regulación de la expresión génica. Las isoformas de eIF4E de levaduras tampoco poseen esta serina fosforilable, probablemente esto se deba a que dicha serina no sea necesaria para la función de dichas proteínas en estos organismos. Asimismo, d4E-HP no posee el residuo K159, a 
pesar de esta falencia, la proteína se ubica en gránulos citoplasmáticos (Fig.11). Esto estaría indicando que aunque la proteína se una débilmente al cap, es suficiente para transportarse junto con este a los gránulos. O posiblemente, se mantenga unida a ARNm por otra vía, asociada con otras proteínas, o tal vez su acumulación en gránulos sea independiente de ARN.

Posteriormente, analizamos la co-localización de las cuatro isoformas de eIF4E estudiadas en esta tesis, con GW182. Se encontró que ambas proteínas co-localizan en un $33 \%$ de los gránulos citoplasmáticos, mientras un 33\% corresponde a gránulos donde solamente se encuentra a GW182 y el otro 33\% a gránulos de eIF4E (Fig. 12, los resultados para la eIF4E-1 pueden observarse en las figuras 22 y 24). Para analizar si eIF4E se localiza en gránulos de estrés se estudió su co-localización con la proteína TIA-1 en células previamente estresadas. Como se muestra en la figura 12, se encontró que eIF4E co-localiza con TIA-1 en el 99\% de los gránulos analizados en células S2 previamente estresadas con arsenito de sodio. Por lo tanto podemos concluir que eIF4E además de encontrarse en PB es encontrada en los SG en células estresadas. 


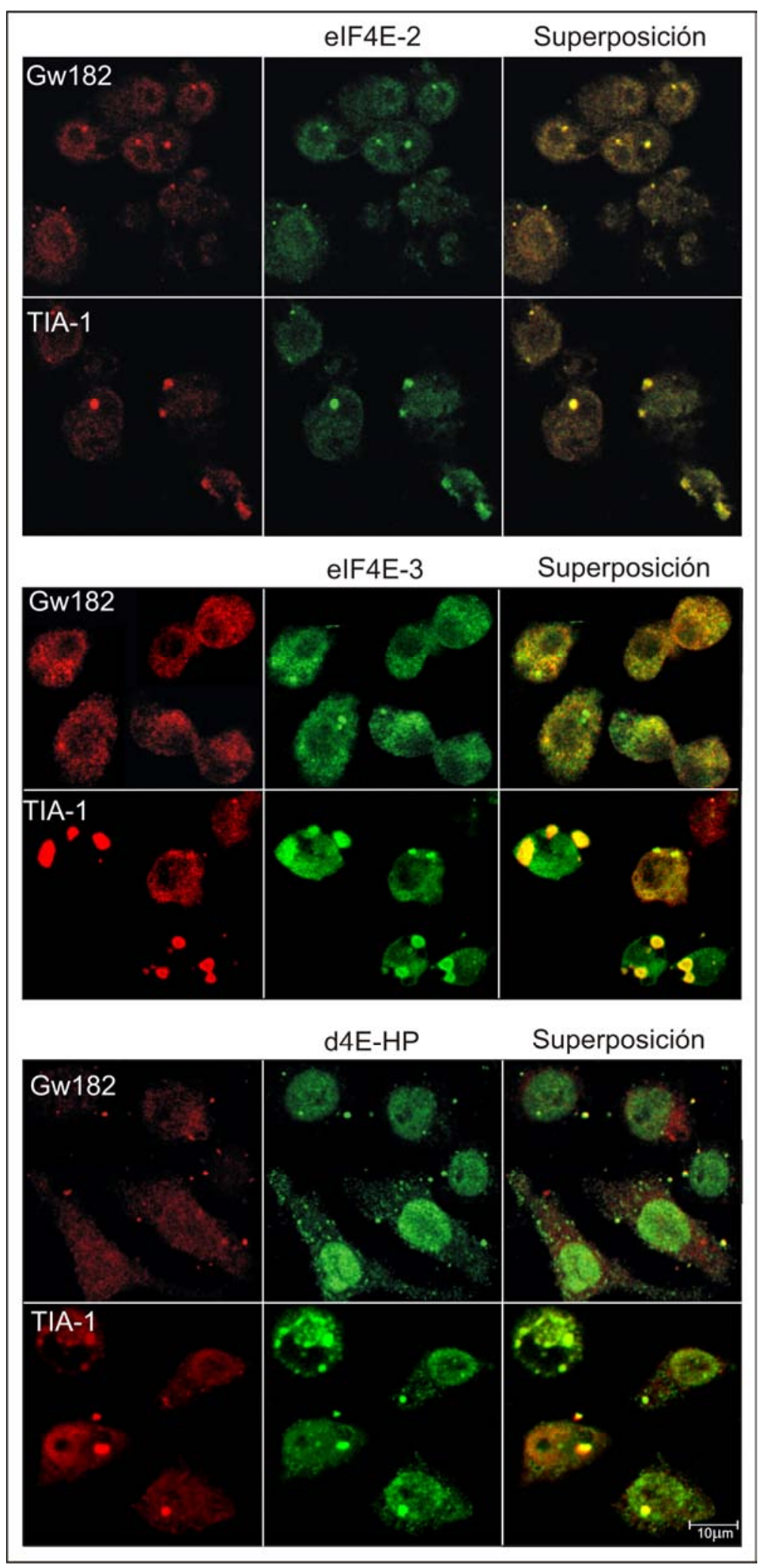

Figura 12. eIF4E se localiza en PB y en SG. Transfección de células S2 con las proteínas de fusión CFP-eIF4E (2, 3 y HP), detección de las proteínas GW182 y TIA-1 por inmuno histoquímica con anticuerpos específicos (Cy3). En los casos en los que se detecta TIA-1 las células fueron previamente estresadas con arsenito. 


\subsubsection{Análisis de co-localización entre componentes de gránulos.}

Una estrategia para dilucidar el mecanismo mediante el cuál las proteínas y los mensajeros se acumulan en los gránulos, es mediante el estudio de las interacciones entre los componentes de los complejos ribonucleoproteicos.

En la figura 13 se muestra un esquema simplificado del remodelamiento de los mRNP, donde un complejo traduccionalmente activo pasa a un estado inactivo, para ello es necesario la participación de varios factores, y el intercambio de componentes. Dilucidar las interacciones entre estos componentes permitirá entender mejor este mecanismo.

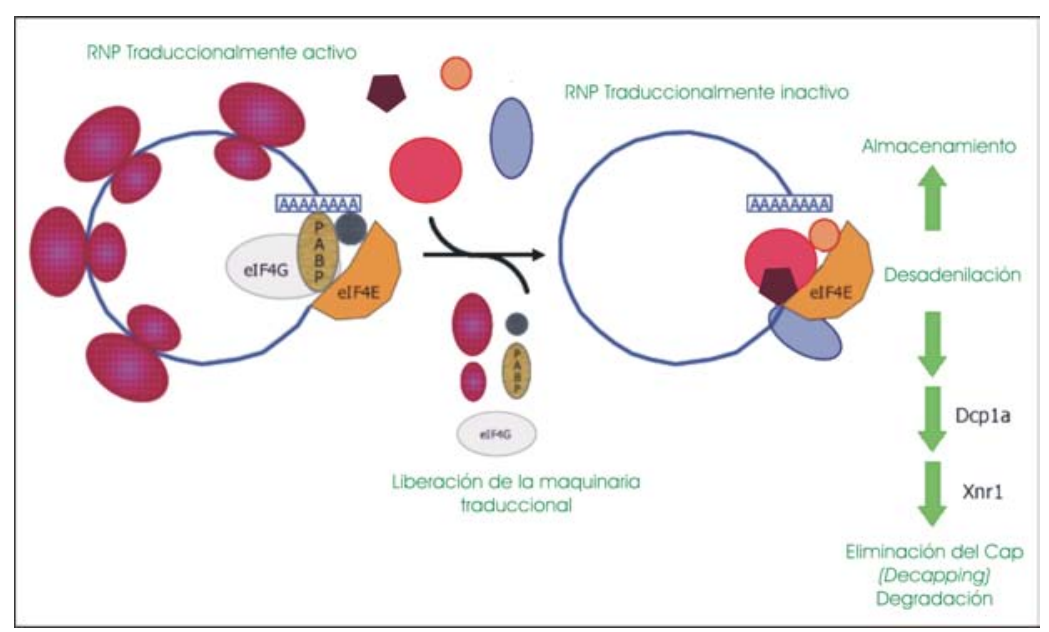

Figura 13. Modelo de remodelamiento secuencial de mRNP. Esquema representativo de cómo un mensajero pasa desde polisomas a PB, mediante intercambio de factores de la maquinaria traduccional por factores de PB.

Un paso previo a la búsqueda de interacciones entre proteínas es establecer su localización conjunta en los mismos gránulos. Previamente, en este capítulo, se demostró que los componentes estudiados se acumulan en PB mediante la colocalización con la proteína GW182. Ahora se analizará si los componentes colocalizan entre sí en las mismas estructuras. 


\subsubsection{1 eIF4E y Me31B co-localizan en PB en células S2 de Drosophila melanogaster}

Nos interesa estudiar si las proteínas eIF4E y Me31B se encuentran asociadas en el mismo tipo de gránulos en células S2. Estudios previos sugieren que ambas proteínas se encuentran agrupadas en los gránulos en diferentes organismos. Minshall y Standart demostraron que Xp54 (ortólogo de Me31B en Xenopus) se une a eIF4E en oocitos de Xenopus (Minshall and Standart, 2004). En humanos se demostró no sólo que ambas proteínas co-localizan en el mismo tipo de gránulos, sino que también se probó su interacción in vivo en gránulos citoplasmáticos en células HeLa (Andrei et al., 2005).

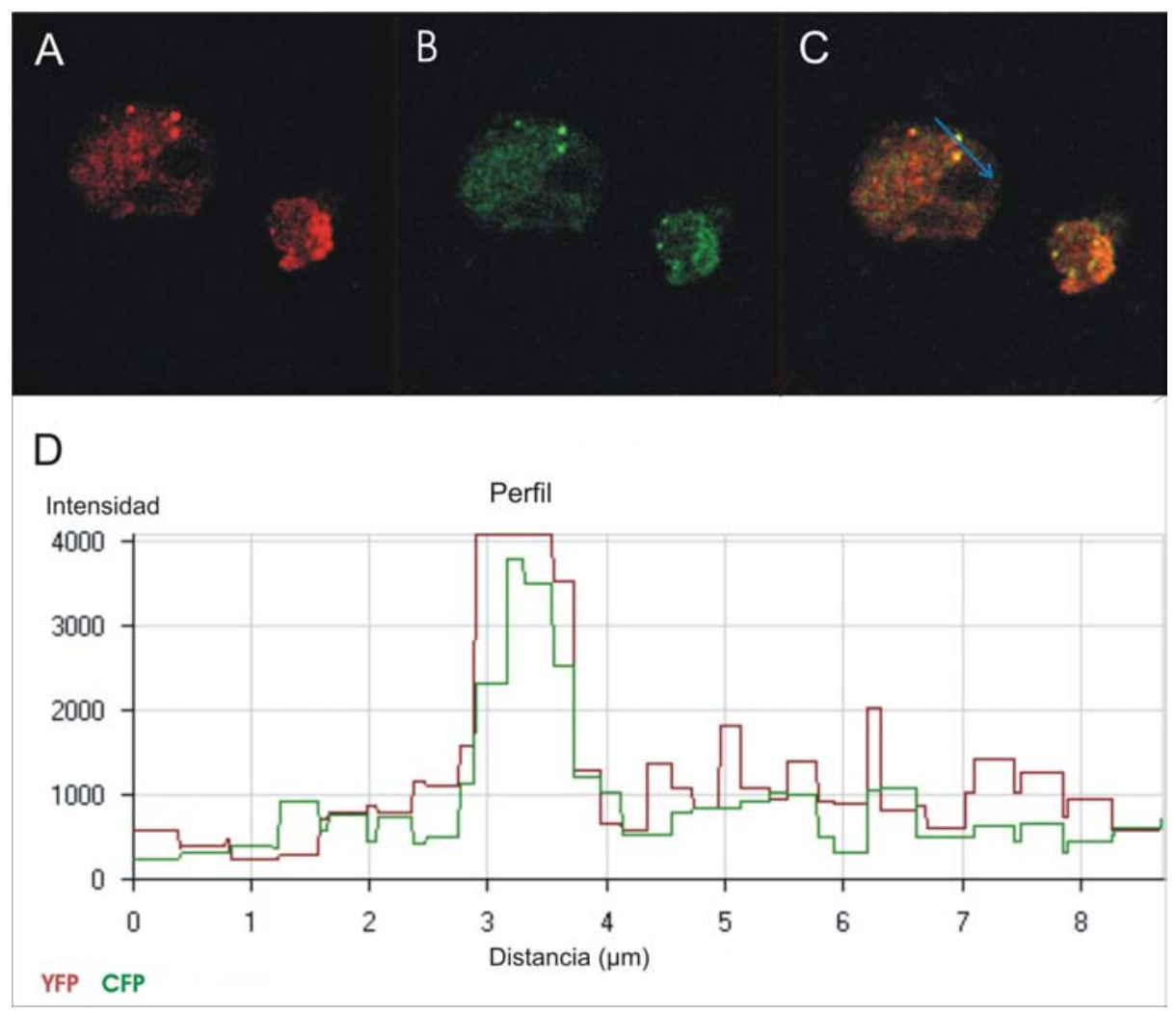

Figura 14. Transfección de células $\mathrm{S} 2$ de $D m$ con las proteínas YFP-Me31B (rojo: A) y CFP- eIF4E-3 (verde: B). En C se observan los gránulos amarillos donde ambas proteínas co-localizan. Se muestra un perfil de intensidades de los dos fluoróforos (D) en función de la distancia de la flecha azul, la cuál atraviesa uno de los gránulos amarillos.

En $D m$ se demostró que Me31B y eIF4E co-localizan en gránulos en ovarios durante toda la oogénesis (Nakamura et al., 2004). Aquí mostramos la co-localización de las proteínas Me31B y eIF4E en PB en células S2 de Dm (Fig. 14, eIF4E-3). Se muestra el 
perfil de intensidades de fluorescencia a través de un gránulo citoplasmático (flecha azul) que contiene a las proteínas YFP-Me31B y CFP-eIF4E-3 (Fig. 14. D). La figura 15 muestra el mismo resultado para las otras isoformas de eIF4E. Este resultado indica que las dos proteínas se encuentran asociadas al mismo tipo de gránulos, y apoya la idea de que Me31B tiene una función crucial en la formación de los PB (Eulalio et al., 2007b), y esta función podría realizarse mediante su interacción (directa o no) con el factor eIF4E.

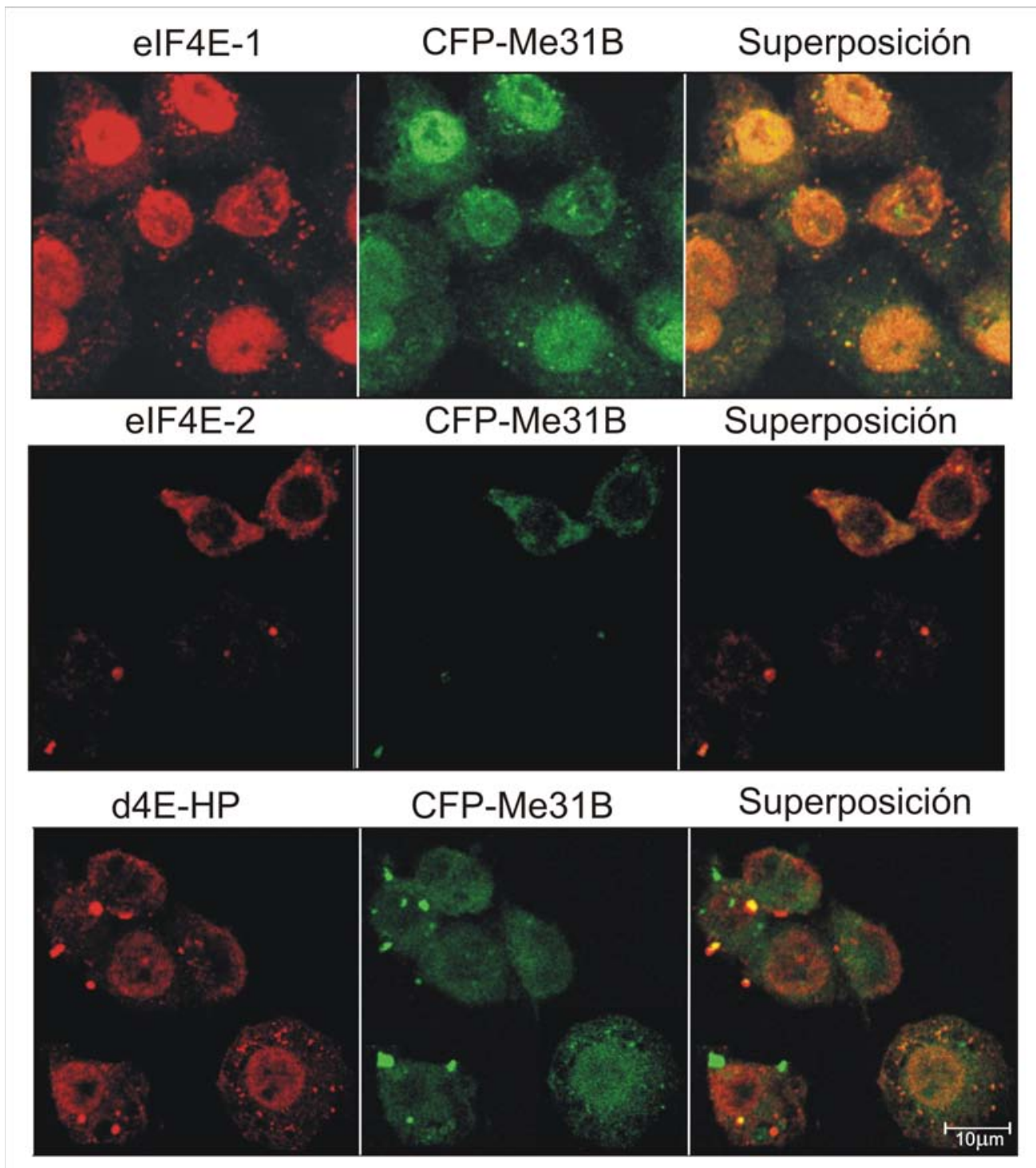

Figura 15. Co-localización de las proteínas Me31B y eIF4E. Se muestra la co-localización de Me31B con las isoformas eIF4E-1, eIF4E-2 y d4E-HP. Se puede observar la variabilidad de gránulos. 


\subsubsection{2 eIF4E y Lsm-1 co-localizan en PB en células S2 de Drosophila melanogaster}

La proteína Lsm-1 ha sido muy estudiada en humanos, fue demostrada su colocalización con otras proteínas del propio complejo Lsm 1-7, así como también con las enzimas de decapping Dcp1 y Dcp2 y con la proteína transportadora de eIF4E (Andrei et al., 2005; Cougot et al., 2004; Ingelfinger et al., 2002) en gránulos citoplasmáticos. El par de interés, Lsm-1/ eIF4E también fue estudiado en humanos demostrándose la co-localización de las dos proteínas en gránulos citoplasmáticos en células HeLa (Andrei et al., 2005).

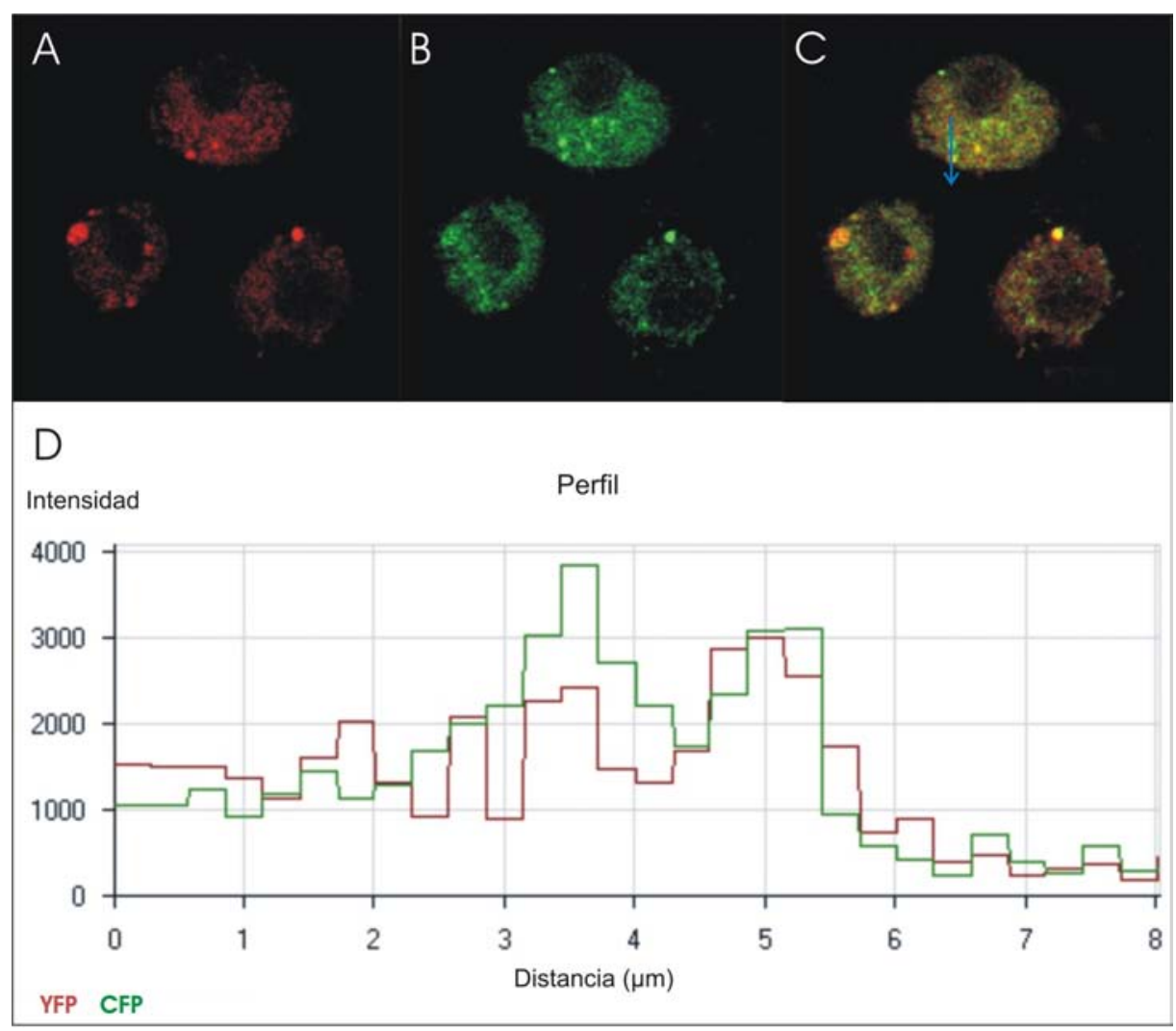

Figura 16. Transfección de células $\mathrm{S} 2$ con las proteínas de fusión YFP-4E-2 (A) y CFP-Lsm-1 (B). En C se muestra la superposición de las imágenes A y B. El gráfico D muestra el perfil de intensidades de ambas proteínas fluorescentes en función de la distancia de la flecha azul.

Aquí demostramos la co-localización en $D m$ de las proteínas Lsm-1 y eIF4E. La figura 16 muestra la co-localización de eIF4E-2 con Lsm-1. Se muestra el perfil de intensidades, en el cuál puede apreciarse que el solapamiento no es en todos los gránulos citoplasmáticos, sino en algunos de ellos. La flecha azul atraviesa dos 
gránulos citoplasmáticos, y en uno sólo de ellos existe solapamiento. La figura 17 muestra el mismo resultado para las otras isoformas de eIF4E.

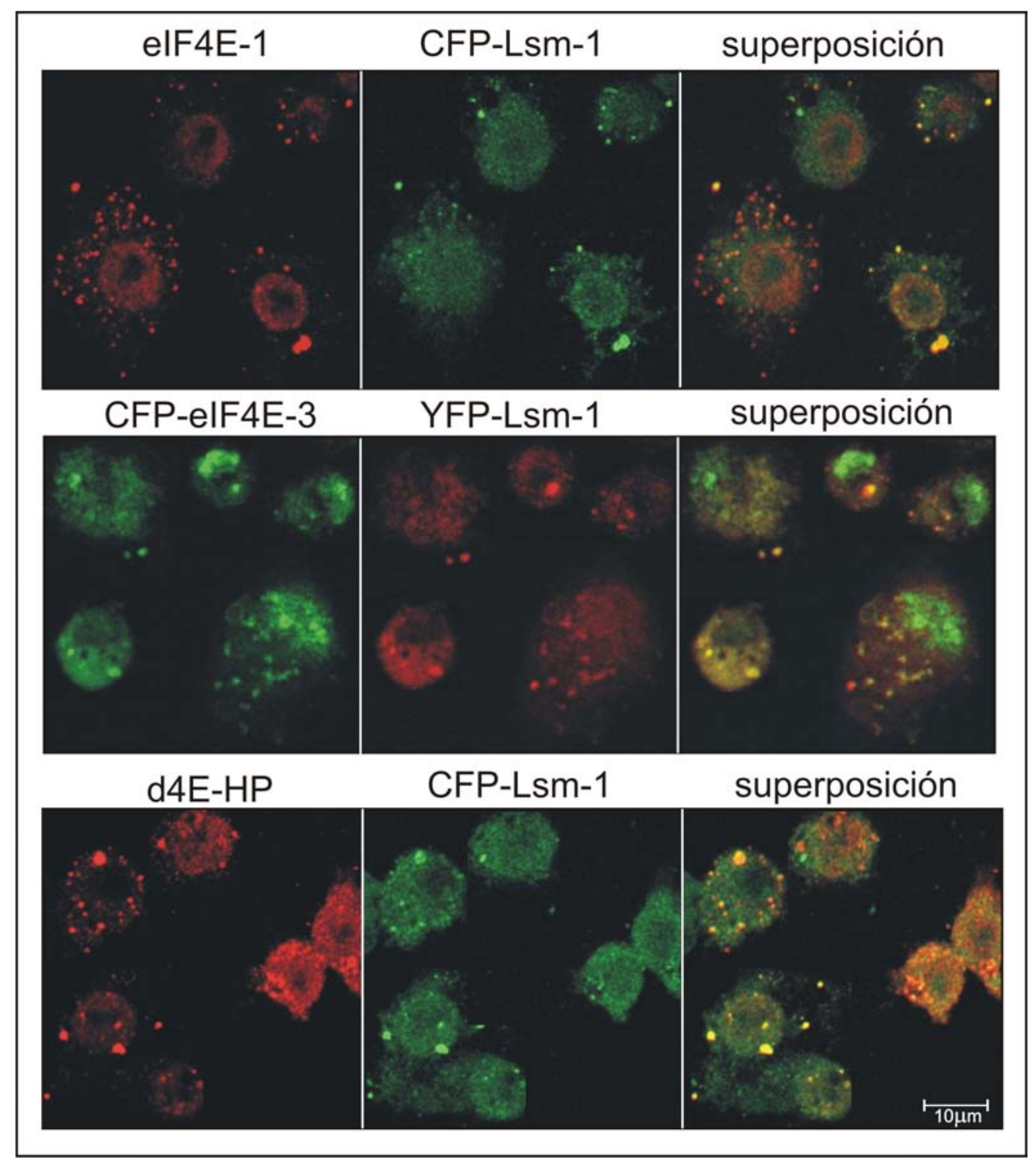

Figura 17. Co-localización de las proteínas Lsm-1 y eIF4E. Se muestra la co-localización de Lsm-1 con las isoformas eIF4E-1, eIF4E-3 y d4E-HP. Se puede observar la variabilidad de gránulos.

\subsubsection{Lsm-1 y Me31B co-localizan en PB en células S2 de Drosophila melanogaster}

No existen muchos antecedentes que analicen conjuntamente a las proteínas Lsm-1 y Me31B, sin embargo, nos resulta imprescindible discernir si ambas proteínas se concentran en las mismas estructuras. Para esto analizamos la co-localización de 
ambas proteínas por transfección de células $\mathrm{S} 2$ de $D m$ con las proteínas de fusión CFPMe31B y YFP-Lsm-1, los resultados se muestran en la figura 18. Se puede observar una clara co-localización entre ambas proteínas en gránulos citoplasmáticos. El perfil de intensidades de los fluoróforos (Fig. 18. D) muestra la co-localización en dos gránulos particulares marcados por la flecha azul (Fig. 18.C).

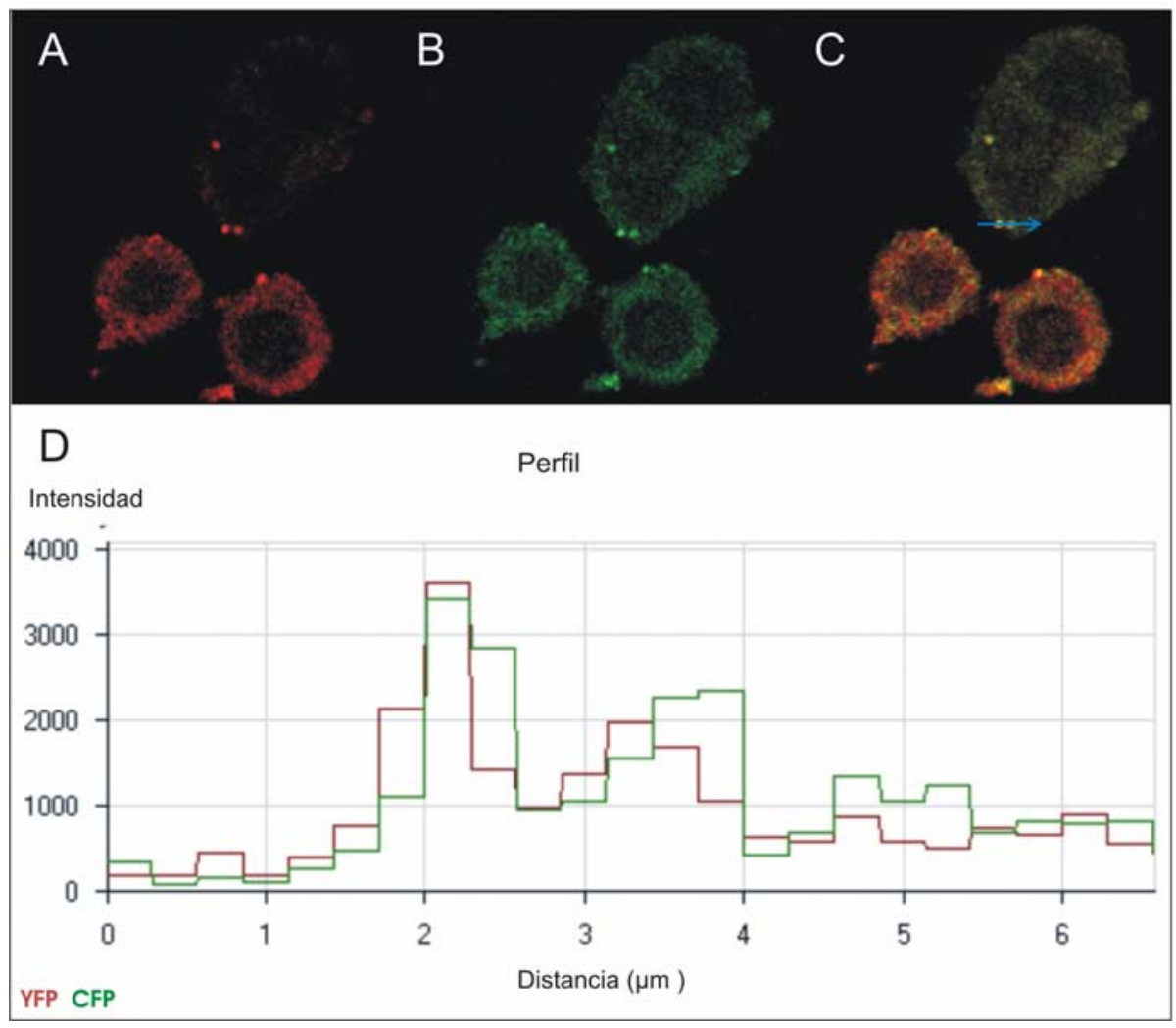

Figura 18. Transfección de células S2 con YFP-Lsm-1 (A) y CFP-Me31B (B). C: co-localización. D: perfil de intensidades de los fluoróforos en función de la distancia marcada por la flecha azul en C.

Podemos concluir, por lo tanto, que las proteínas Me31B y Lsm-1 se encuentran juntas, formando parte del mismo tipo de gránulos en el citoplasma de células $\mathrm{S} 2$.

En el capitulo 3 de esta tesis se procederá a evaluar las interacciones directas entre las proteínas analizadas en esta sección mediante FRET. 


\section{Discusión}

Durante el primer capítulo de esta tesis se realizo el estudio de la composición de los complejos mRNP en el citoplasma de células $\mathrm{S} 2$ de $\mathrm{Dm}$. Nos enfocamos a algunas de las proteínas más relevantes en el proceso de regulación post-transcripcional.

Los gránulos citoplasmáticos de ARNm pueden ser encontrados en una gran variedad de configuraciones de acuerdo a su contenido de proteínas. Estas estructuras tienen roles importantes en la regulación post-transcripcional de la expresión genética (Anderson and Kedersha, 2006). El contenido de proteínas es un usual indicador del tipo de gránulo, los SG y PB comparten varios componentes proteicos, aunque algunas proteínas son exclusivas de cada tipo de gránulo (Eulalio et al 2007).

Las 4 isoformas del factor de inicio de la traducción eucariota analizadas en esta tesis (eIF4E-1, eIF4E-2, eIF4E-3 y d4E-HP) fueron encontradas en gránulos citoplasmáticos constitutivos, algunos de los cuáles contienen a la proteína marcadora de PB, GW182. Asimismo, las cuatro isoformas fueron encontradas formando parte de los gránulos de estrés inducidos por arsenito de sodio. Este resultado es novedoso para células de Drosophila y concuerda con los resultados encontrados en células humanas y en levaduras (Brengues and Parker, 2007; Kedersha et al., 2005).

Es interesante analizar el caso de eIF4E-3, esta isoforma carece del residuo K159, indispensable para estabilizar la unión de la proteína al cap de los mensajeros. Este aminoácido forma un puente salino retráctil con el residuo S209 que estabiliza fuertemente dicha unión. Sin embargo, a pesar de ello, la encontramos ubicada en PB. Estas estructuras se conocen por su función como sitios de acumulación de mensajeros, los cuales son degradados, o almacenados hasta que vuelven ciclos de traducción activa. Las evidencias existentes en varios organismos, hasta ahora, sugieren que eIF4E debe permanecer unida al cap de los mensajeros para ser dirigida junto a ellos y a otras proteínas desde los polisomas hacia los PB. Por lo tanto, el hecho de que esta isoforma carezca de este residuo, haría pensar en principio que no sería capaz de ir a PB, sin embargo fue demostrado que la proteína puede unirse al cap in vitro (Hernandez et al., 2005). Asimismo aquí demostramos que se ubica en PB. Por lo tanto, es factible que la unión de eIF4E-3 al cap se produzca también in vivo, y sea 
junto al ARNm que la proteína se dirige hacia los gránulos. La otra opción factible es que no sea necesaria la unión de la proteína al cap para que la misma se dirija a PB.

Otro caso interesante, similar al anterior, es el de d4E-HP, esta isoforma carece del residuo S209. Como se mencionó anteriormente esta proteína se une débilmente al cap in vitro, sin embargo, se encuentra en gránulos citoplasmáticos constitutivos. Su ubicación en estos mRNP se puede explicar con el hecho de que esta proteína es capaz de unir ARN de un modo independiente de cap y/o transportarse a dichos gránulos junto con otras proteínas formando parte de un complejo.

Tanto eIF4E-3 como d4E-HP, fueron encontradas además en SG generados mediante tratamiento con arsenito de sodio.

Para sintetizar, podemos decir que, eIF4E es una proteína que participa activamente en el proceso de iniciación de la traducción de los ARNm, a su vez, es un factor que participa en el silenciamiento de los mismos; se ubica tanto en PB, estructuras de silenciamiento de ARNm constitutivas, como en SG, estructuras de silenciamiento de ARNm transitorias donde los mensajeros son almacenados hasta volver a ciclos de traducción. De hecho es la única proteína que participa en la traducción que hasta el momento fue encontrada en ambas estructuras de silenciamiento en $\mathrm{Dm}$. En el capitulo 2 se estudiará con más detalle esta proteína, tratando de dilucidar los sitios importantes para su localización en PB.

Por otro lado, mostramos que la helicasa Me31B y la proteína Lsm-1 se ubican exclusivamente en gránulos correspondientes a PB. A diferencia de lo que ocurre con eIF4E, estas dos proteínas no fueron encontradas en SG. Por lo tanto, se puede esperar, que participen activamente en el silenciamiento y/o degradación de mensajeros en gránulos en condiciones celulares fisiológicas. Sin embargo, parece que no participan en dichas funciones cuando se producen situaciones de estrés celular.

En este trabajo también se demostró la co-localización entre las proteínas eIF4E y Me31B, para las 4 isoformas de eIF4E estudiadas, esto indica que las proteínas se encuentran juntas en el mismo tipo de gránulos. Asimismo encontramos que tanto las proteínas eIF4E como Me31B co-localizan con Lsm-1, por lo tanto podemos decir que todas las proteínas se encuentran juntas formando mRNP en el mismo tipo de gránulo citoplasmático, estos gránulos son $\mathrm{PB}$, ya que anteriormente demostramos la colocalización con GW182. 
Hay que destacar que, en todo este análisis nos encontramos con gran variabilidad entre los gránulos, ya que, al analizar co-localizaciones con GW182 se observaron varios tipos de gránulos que podemos definir como "gránulos mixtos" (donde se observa co-localización) o "gránulos individuales" (donde se encuentra sólo GW182 y no la otra proteína estudiada o viceversa). Existe, en promedio, aproximadamente un $33 \%$ de cada tipo de gránulo cualquiera sea la proteína analizada. Podemos sugerir que este conjunto de gránulos corresponde a PB en diferentes estados, ya que existe una dinámica de intercambio de componentes muy activa. Hay que tener presente también, que las concentraciones de las proteínas en los gránulos pueden modificarse y no ser detectadas microscópicamente.

Hemos realizado hasta aquí una pequeña caracterización de los gránulos citoplasmáticos en células $\mathrm{S} 2$ de $\mathrm{Dm}$, nos enfocamos principalmente en tres proteínas eIF4E (en 4 de sus isoformas), Me31B y Lsm-1. Creemos que estas proteínas tienen un rol crucial en la formación de $\mathrm{PB}$, de hecho, se sabe que la depleción de Me31B o Lsm-1 reduce notablemente la presencia de dichos gránulos (Eulalio et al., 2007b). En los capítulos siguientes ampliaremos el estudio de estos factores. 


\section{Capítulo 2.}

\subsection{Estudio funcional de eIF4E en el reclutamiento hacia PB.}

Hasta aquí hemos analizado y caracterizado a eIF4E como un componente de gránulos citoplasmáticos, tanto de PB como SG. Inclusive vimos que varias isoformas se ubican en los dos tipos de gránulos. Ahora trataremos de evaluar qué sitios de eIF4E son indispensables para su localización en estos gránulos. Como ya se mencionó en el capítulo I, en la estructura de eIF4E existen algunos aminoácidos que son esenciales para que la proteína pueda llevar a cabo sus funciones. En este capítulo estudiaremos los aminoácidos triptófano 56 (W56) y triptófano 102 (W102) descriptos en mamíferos, que son algunos de los responsables de la unión de eIF4E al cap, y el aminoácido triptófano 73 (W73) que es requerido para la interacción con proteínas portadoras del motivo Y-X-X-X-X-L-, tal como eIF4G, 4E-BP y Cup (Niedzwiecka et al., 2002). Una búsqueda detallada en bancos de datos genómicos muestra que, al menos en Drosophila, proteínas de funciones variadas y no sólo relacionadas con la síntesis proteica, desde factores de transcripción hasta componentes del proteasoma, presentan este motivo (R. Rivera-Pomar, no publicado). Los sitios mencionados se corresponden con los W100, W146 y W117 respectivamente de eIF4E-1 de Drosophila melanogaster (Fig. 19). Evaluaremos específicamente que ocurre con la ubicación de eIF4E-1 cuando se alteran los sitios antes mencionados. Se trabajará con esta isoforma debido a que es la que se expresa durante todo el ciclo de vida de Drosophila, es la que se encarga de la unión al cap en los embriones, donde también están presentes eIF4E-3 y d4E-HP pero en menor cantidad, las demás isoformas no fueron encontradas en embriones (Hernandez et al., 2005). 


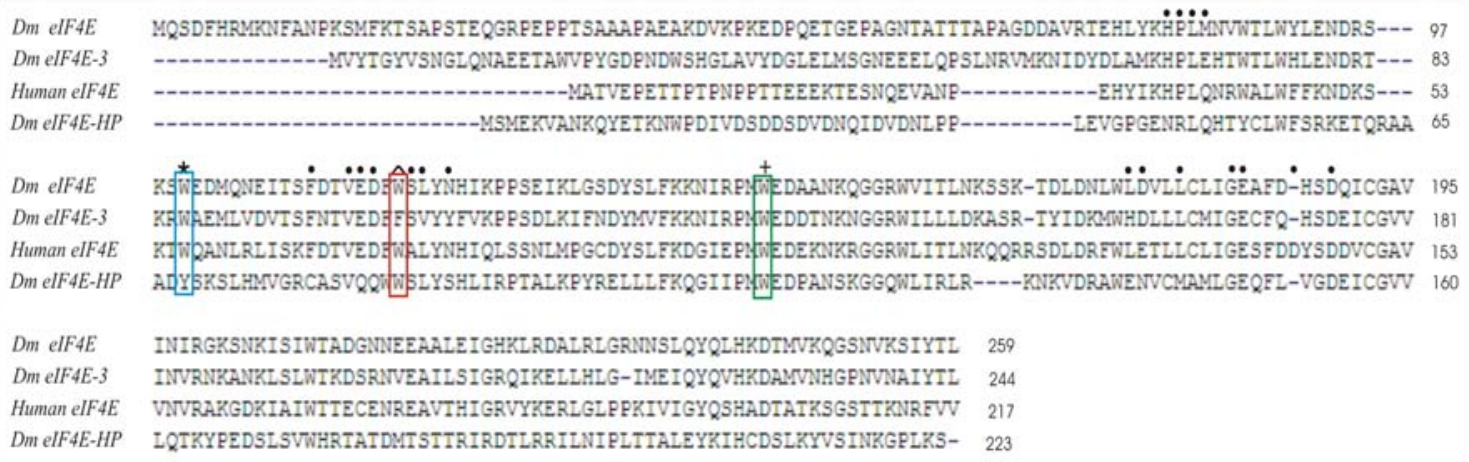

Figura 19. Alineamiento de la secuencia de aminoácidos de eIF4E de Drosophila (1,3, HP) y eIF4E Humana. Los residuos involucrados en el reconocimiento del cap están marcados como sigue: el asterisco $\left(^{*}\right)$ indica la posición del residuo W100 para deIF4E-1 (W56 para la humana, W86 para eIF4E-3 y Y68 para d4E-HP) y el signo (+) marca el residuo W146 para deIF4E-1 (W102 para la humana, W132 para eIF4E-3, y W114 para d4E-HP. El residuo triptofano que participa en la unión con eIF4G y 4E-BP (heIF4E W73, eIF4E-1 W117, eIF4E-3 F103, d4E-HP W85 ) está señalado con el signo $\left({ }^{\wedge}\right)$. Los otros residuos que participan en esta unión están marcados con puntos $(\bullet)$.

\subsubsection{El reclutamiento de eIF4E hacia $P B$ es independiente de su actividad de unión al cap.}

Los estudios estructurales en los mamíferos y el análisis comparativo mostró que los residuos W100 y W146 de eIF4E-1 de Drosophila, interactúan con el m7GpppN del ARNm (Hernandez et al., 2005; Marcotrigiano et al., 2001). Con el objetivo de investigar si estos residuos son necesarios para la localización de eIF4E en PB, hemos generado mutantes en cada uno de los sitios y un doble mutante con ambos sitios alterados. Con ellos se transfectaron células $\mathrm{S} 2$ de $D m$ y se evaluó la localización celular de las proteínas. La figura 20 muestra que los mutantes eIF4E-1 ${ }^{\text {W100A }}$, eIF4E-1 ${ }^{\text {W146A }}$ y el doble mutante eIF4E-1 W100A/W146A se localizan en gránulos citoplasmáticos, al igual que lo hace la forma de tipo salvaje. 


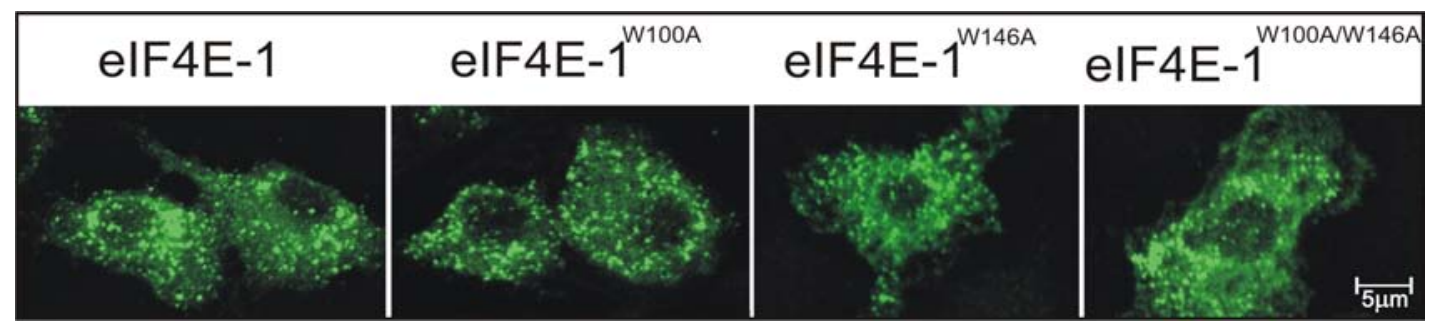

Figura 20. Transfección de células $S 2$ con pMT/V5-eIF4E-1 y los mutantes en los sitios W100A, W146A, y el doble mutante W100A/W146A en el mismo vector. Se detectó por inmuno histoquímica con anti-V5, Cy3.

Se realizó un control transfectando células con el vector pMT/V5-His vacío, para asegurarnos de que los gránulos citoplasmáticos observados en la figura anterior se deban a las proteínas expresadas, y no sea un efecto indeseable propio del vector. En este control se realizó además inmuno histoquímica para los marcadores GW182 y TIA-1 que serán utilizados posteriormente (Fig. 21).

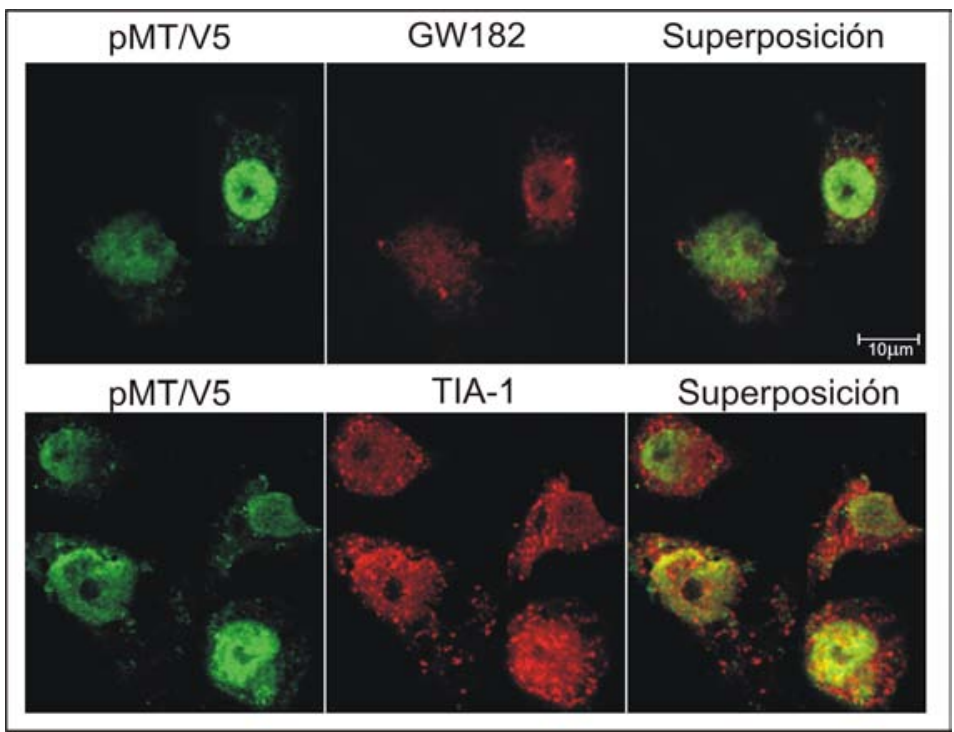

Figura 21. Control de transfección con el vector pMT/V5-His vacío. No se observa acumulación del vector vacío en gránulos.

Para establecer si los mutantes se ubican tanto en PB como en SG se realizaron transfecciones de células S2 con los diferentes mutantes y se marcaron los gránulos con anticuerpos específicos contra proteínas presentes en PB y SG. La figura 22 muestra que eIF4E de tipo salvaje co-localiza con GW182 en PB, así como lo hacen eIF4E W100A, eIF4E ${ }^{\text {W146A }}$ y eIF4E ${ }^{\text {W100A/W146A }}$. Estos resultados concuerdan con los 
obtenidos en el capitulo 1 referidos d4E-HP, esta isoforma posee el residuo Y68 en la posición correspondiente al aminoácido W100 de eIF4E-1 y sin embargo, se demostró que se encuentra en PB. Por lo tanto, podemos concluir que los residuos W de eIF4E claves para su unión al cap no son necesarios para la localización en PB, ya que incluso el doble mutante se ubica en gránulos. Asimismo, d4E-HP carece de otro residuo importante para la unión al cap (S209). De la misma manera, en el capitulo I demostramos que eIF4E-3 también se ubica en gránulos a pesar de carecer de otro residuo clave para dicha unión (K159). Por lo tanto, todas las evidencias sugieren que la unión al cap no es el factor limitante para la ubicación de eIF4E en gránulos citoplasmáticos. Por otro lado, se observó que eIF4E y los mutantes también se agregan en gránulos citoplasmáticos desprovistos de GW182. Esto implica, como se ha propuesto previamente, que los gránulos citoplasmáticos son una familia polimórfica con diferentes estadios de maduración.

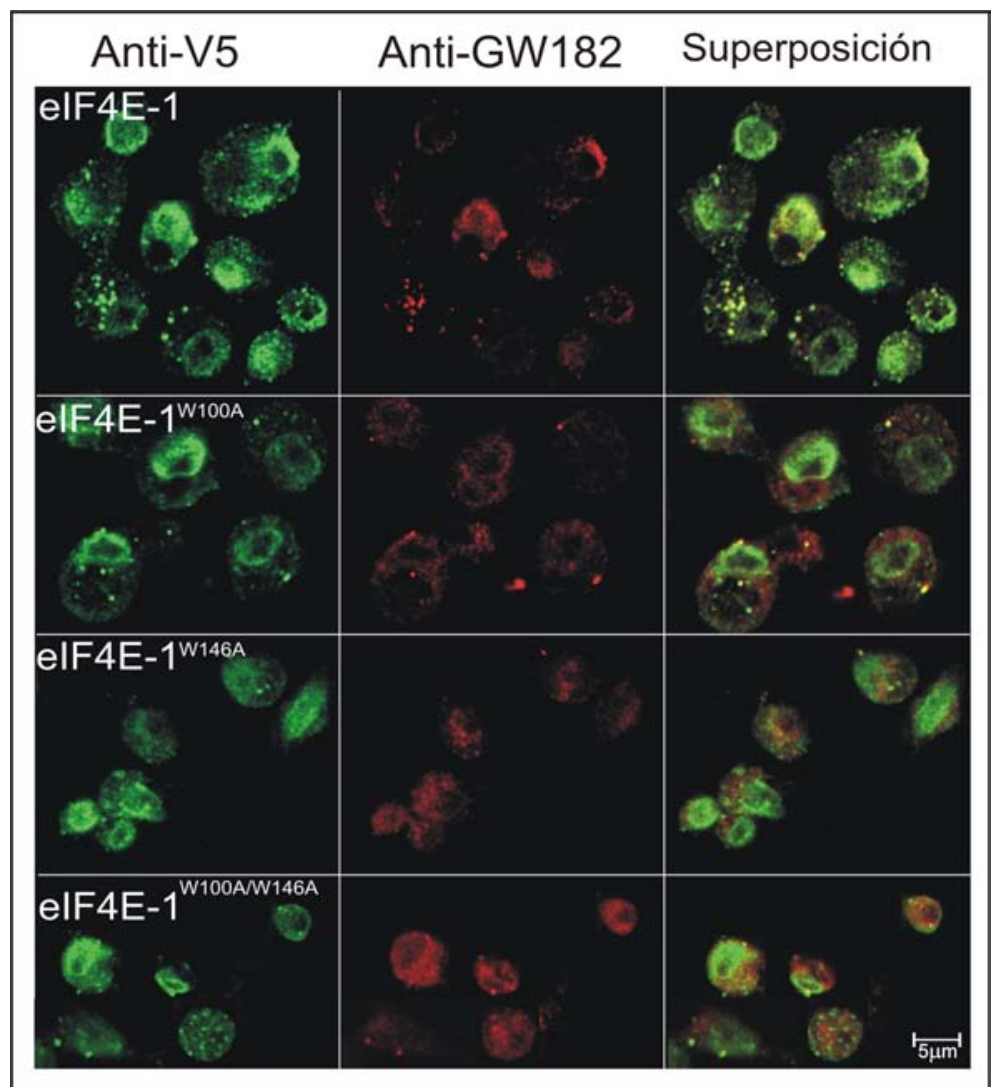

Figura. 22. Transfección de células $\mathrm{S} 2$ con pMT/V5-eIF4E-1, pMT/V5-eIF4E-1 ${ }^{\mathrm{w} 100 \mathrm{~A}}$, pMT/V5eIF4E-1 ${ }^{\text {W146A }}$ y pMTV5-eIF4E-1 ${ }^{\text {W100A/W146A }}$. Detección con los anticuerpos anti-V5, Cy2 y con antiGW182, Cy3. 
Con el objetivo de evaluar si existen diferencias en la ubicación en PB de eIF4E con respecto a los mutantes, se realizó un ensayo estadístico. En el mismo se evaluó la cantidad de gránulos que contienen tanto eIF4E como GW182 con respecto a los PB totales (considerados como gránulos de GW182) por célula. Se realizó un ensayo de ANOVA para ver si existía diferencia significativa. Observamos una gran dispersión en los resultados la cuál puede ser atribuida al polimorfismo de los gránulos mencionado anteriormente. En la figura 23 se observa que aparentemente, existe menor cantidad de PB que contienen a los mutantes con respecto a los PB que contienen a eIF4E salvaje. Sin embargo no se encontraron diferencias significativas para un $\mathrm{p}=0,05$. Por lo tanto, esta tendencia es despreciable, y podemos afirmar que los triptófanos que participan en la unión al cap no afectan la ubicación de eIF4E en PB.

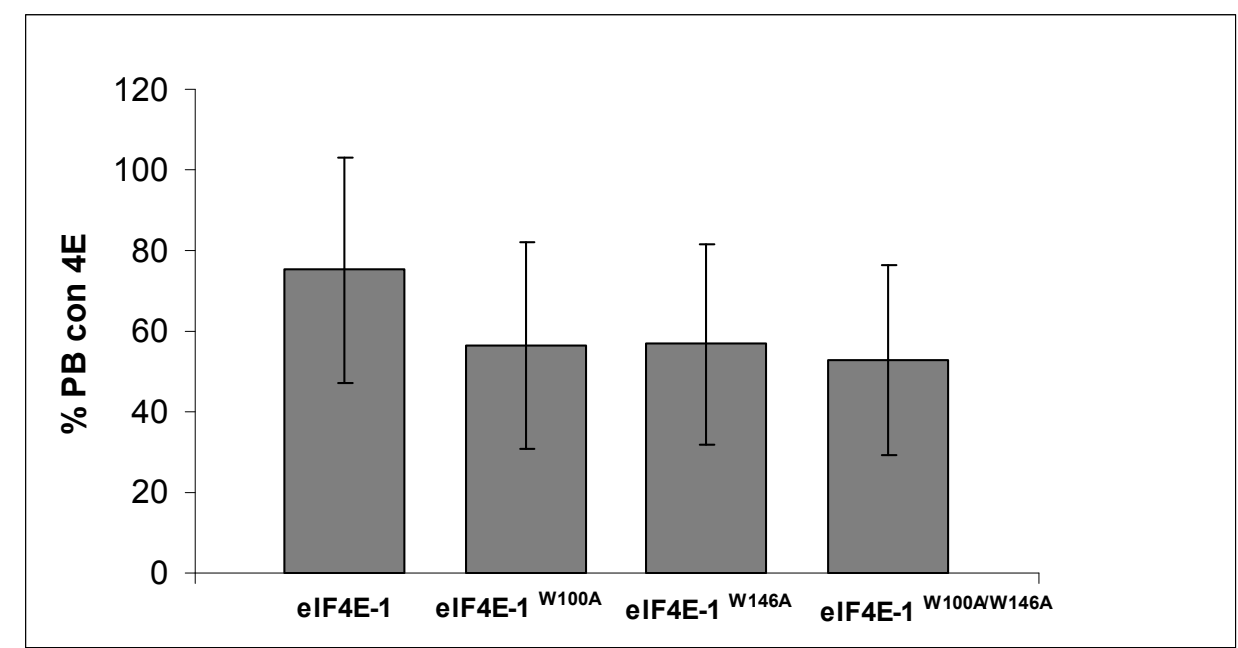

Figura. 23. Grafico de barras donde se muestra el porcentaje de PB que contienen eIF4E con respecto al total de PB. No existe diferencia significativa entre eIF4E salvaje y los mutantes.

Como eIF4E también se ha encontrado en gránulos de estrés (Fig.12), se procedió a determinar si el sitio de unión al cap afecta la acumulación de eIF4E en SG. Analizamos la co-localización de las variantes de eIF4E con TIA-1, en células transfectadas y estresadas con arsenito de sodio. Luego del estrés con arsenito tanto eIF4E salvaje como los mutantes co- localizan con TIA-1 (Fig. 24).

Aproximadamente el $99 \%$ de la forma salvaje de eIF4E está presente en SG inducidos por arsenito de sodio. Asimismo, el porcentaje de los mutantes encontrados 
en SG es muy similar: $94 \%$ para eIF4E $\mathrm{E}^{\mathrm{W} 100 \mathrm{~A}}$, 96\% para eIF4E ${ }^{\mathrm{W} 146 \mathrm{~A}}$, y $97 \%$ para eIF4E $^{\mathrm{W} 100 \mathrm{~A} / \mathrm{W} 146 \mathrm{~A}}$ (Fig. 25). Se realizó un ensayo de ANOVA y se encontró que no existe diferencia significativa $(\mathrm{p}=0,05)$ en la distribución de eIF4E salvaje y los mutantes en SG.

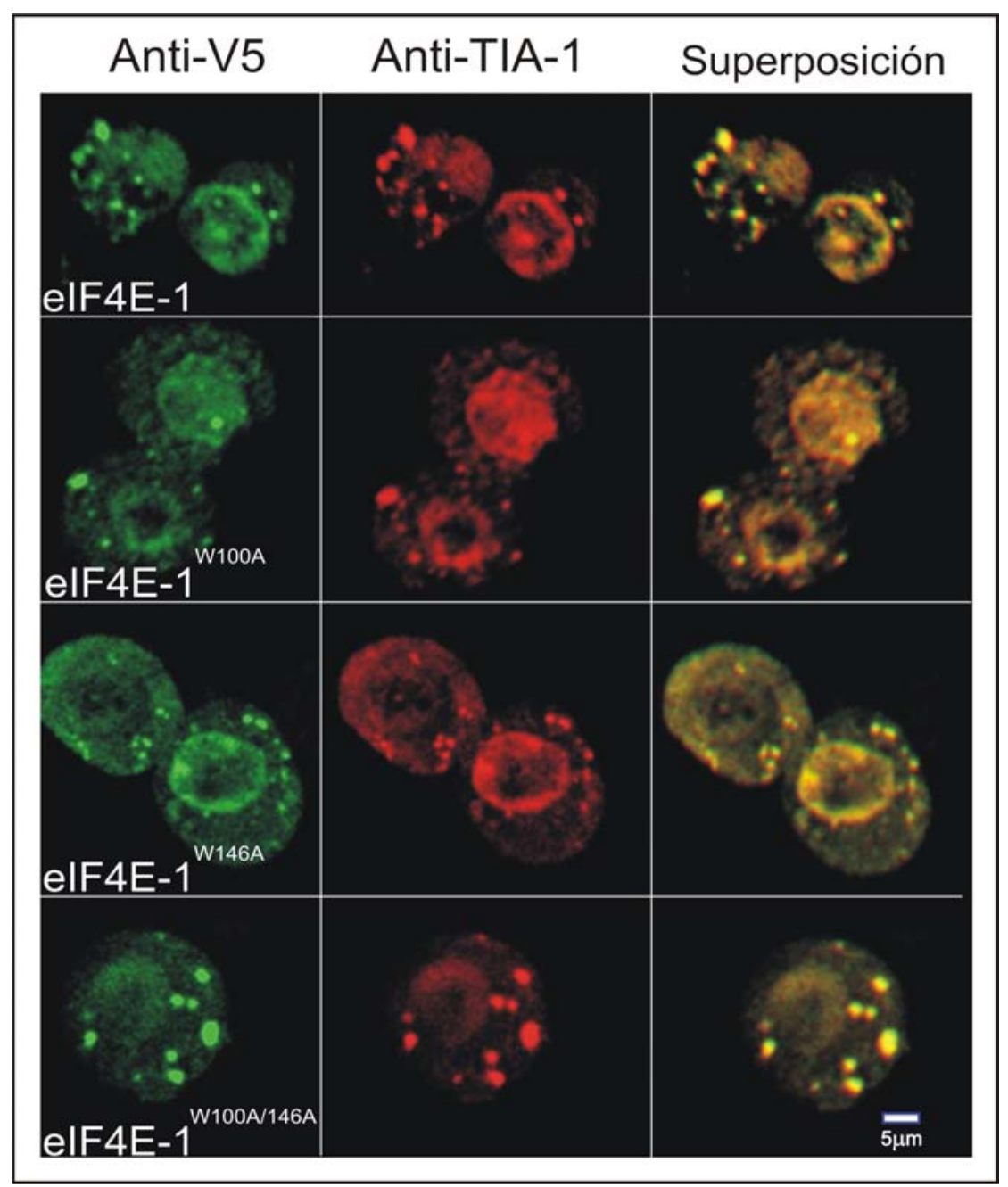

Figura 24. Células S2 transfectadas con eIF4E y las formas mutantes (Cy2, verde). Todas las variantes de eIF4E co-localizan con el marcador de SG (TIA-1, Cy3, rojo) en presencia de estrés generado por arsenito de sodio. 


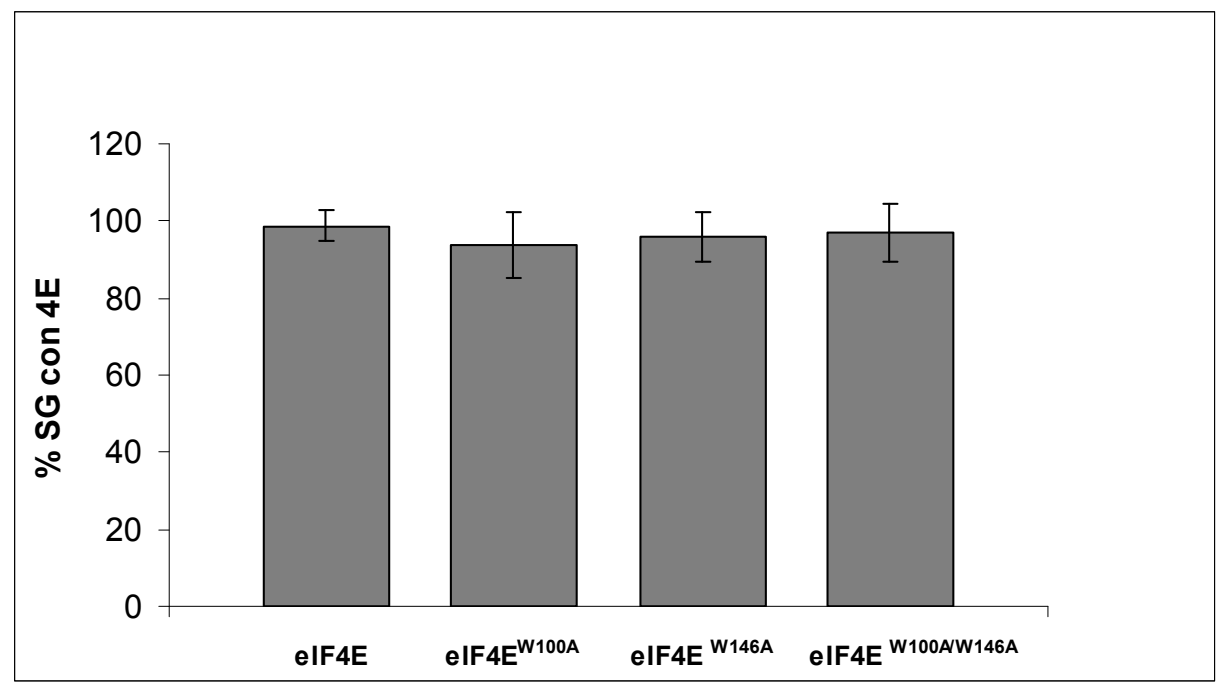

Figura 25. Grafico de barras donde se muestra el porcentaje de SG que contienen eIF4E con respecto al total de SG. No existe diferencia significativa entre eIF4E salvaje y los mutantes.

En la figura 26 puede apreciarse que en ausencia de estrés TIA-1 no se acumula en gránulos mientras que eIF4E y sus mutantes si lo hacen. 


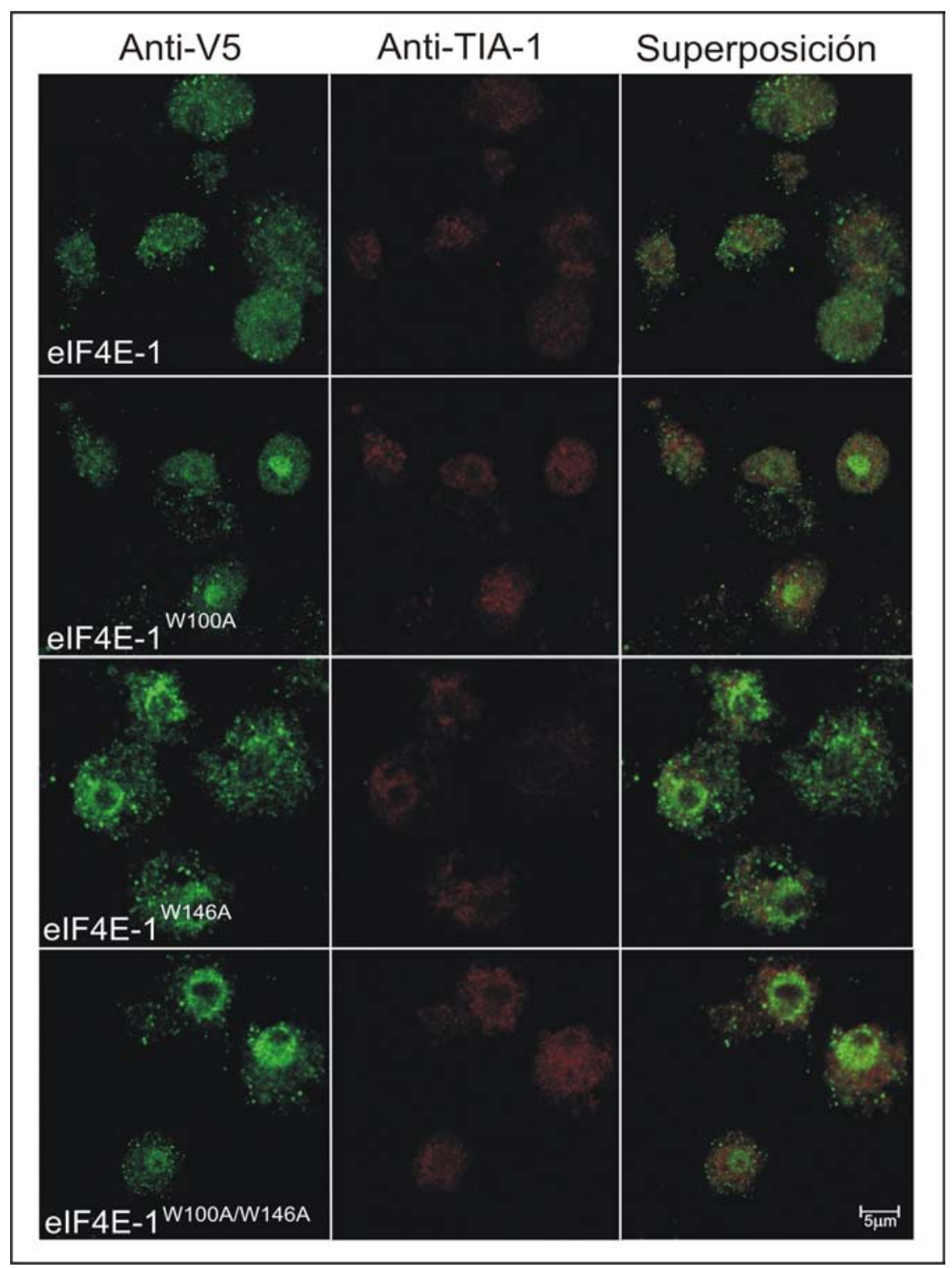

Figura 26. Células $\mathrm{S} 2$ transfectadas con eIF4E y las formas mutantes (Cy2, verde), inmuno histoquímica para el marcador de SG (TIA-1, Cy3, rojo) en ausencia de estrés.

Una vez demostrado el hecho de que la unión al cap no está involucrada en la localización de eIF4E en gránulos, nos interesa evaluar la procedencia de la proteína que se acumula en estos sitios. Debido a que la unión al cap no participa en este proceso, podría pensarse que la proteína no proviene de los polisomas. eIF4E se encuentra normalmente en el citoplasma formando parte de los polisomas, así como también existe una fracción libre distribuída por el citoplasma, una fracción nuclear y la fracción que se encuentra formando parte de los gránulos citoplasmáticos. Para evaluar si el origen de eIF4E que se acumula en gránulos proviene de la fracción 
asociada a la traducción (lo que se encuentra en los polisomas) o de la fracción libre en el citoplasma, se trataron a las células con un inhibidor de la traducción. Se utilizó cicloheximida, droga que bloquea la fase de elongación de la traducción. Al inhibirse la traducción se produce la acumulación del ARNm en polisomas. En estos polisomas va a estar acumulada consecuentemente eIF4E. La figura 27 muestra que el tratamiento de células S2 de $D m$ con cicloheximida previene la acumulación tanto de eIF4E como de sus mutantes en PB (gránulos que contienen GW182).

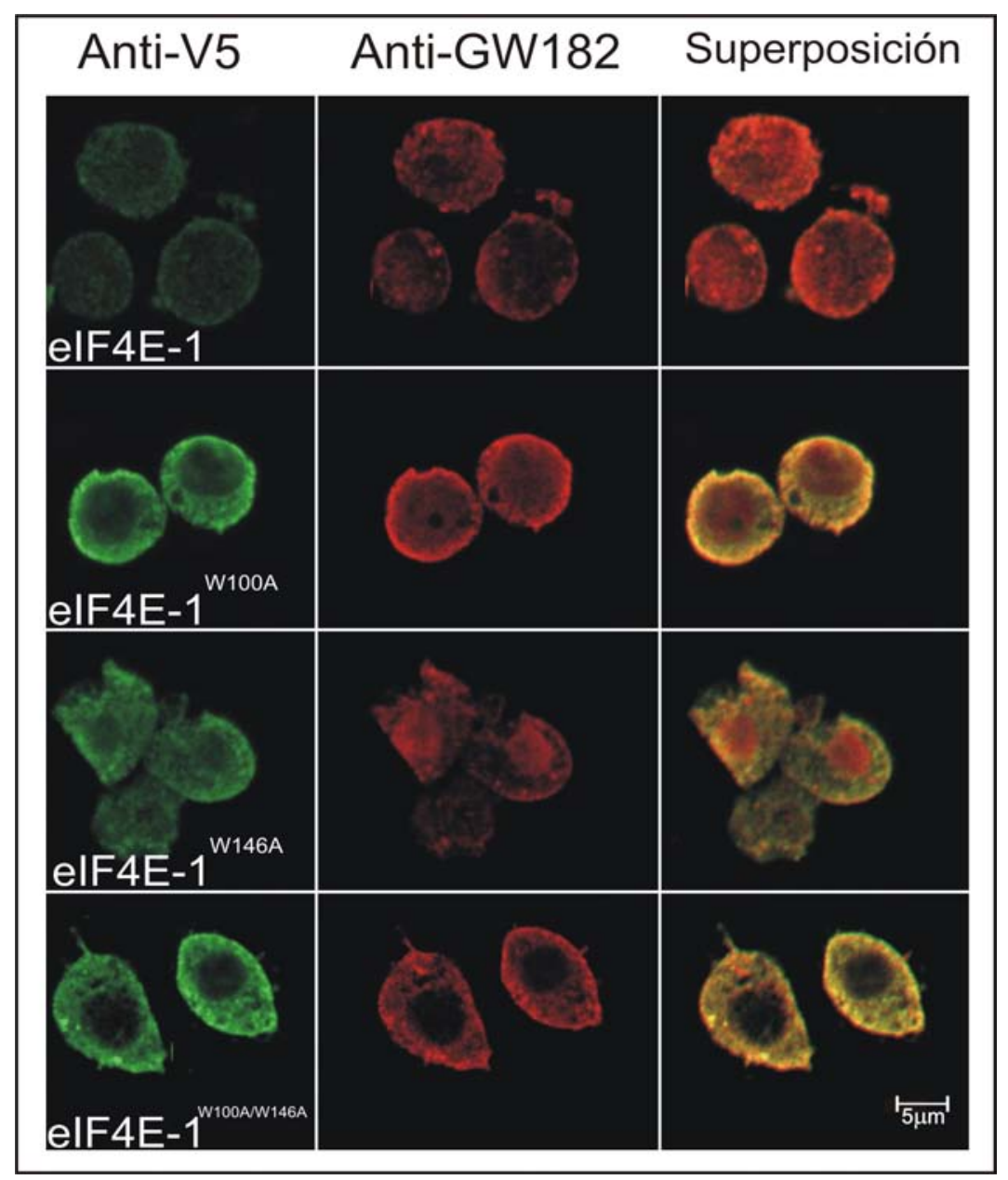

Figura 27. Distribución de eIF4E salvaje y mutantes después del tratamiento con cicloheximida en células $\mathrm{S} 2$. Se ve una notable disminución del número y tamaño de PB en todos los casos.

Estos resultados sugieren que al menos una fracción importante de eIF4E se dirige a PB desde los polisomas, pero estas moléculas no estarían necesariamente asociadas al ARNm vía cap. Esto concuerda con la idea de que eIF4E participa en la remodelación de mRNP desde un estado activo a otro inactivo, ya sea como un transportador o por 
reclutamiento de otros factores. Pareciera ser que estas dos últimas tareas no puede realizarlas cuando está unida al cap de los mensajeros.

\subsubsection{El reclutamiento de eIF4E hacia $\mathrm{PB}$ requiere el aminoácido W117}

Si la movilización de eIF4E de polisomas a PB y SG es independiente de la unión a cap, entonces nos preguntamos si los dominios necesarios para interactuar con las otras proteínas se encargarían de esto. Como se mencionó anteriormente, eIF4E interactúa con otras proteínas que participan en el proceso de la traducción (4E-BP, eIF4G, ausentes en PB) y con algunas no asociadas a la traducción como eIF4E-T (presente en PB). Se realizaron mutantes de eIF4E-1 de Drosophila en el aminoácido W117, el cuál es requerido para su interacción con eIF4G, 4E-BP, y eIF4E-T.

Se observó que los mutantes eIF4E-1 $1^{\mathrm{W} 117 \mathrm{~A}}$ no se localizan en gránulos citoplasmáticos sino dispersos por todo el citoplasma de células S2 (Fig.28). Esto podría indicar que no se encontrará ni en PB ni en SG. En la figura 29 (panel superior) se muestra que el mutante no se encuentra en PB (en este caso, los PB fueron detectados mediante la proteína Me31B, en el capitulo 1 se demostró que esta proteína se encuentra en PB). Esto concuerda con resultados previos en células HeLa donde se vio que eIF4E ${ }^{\text {W73A }}$ (correspondiente a W117 en eIF4E-1 Dm) deslocaliza de PB (Ferraiuolo et al., 2005). Por lo tanto, sugerimos que el transporte de eIF4E a PB requiere el dominio de interacción proteína-proteína. Esto estaría indicando que es necesaria la unión de algún factor a este sitio para que eIF4E sea transportada a gránulos citoplasmáticos.

Para evaluar si el mutante se localiza en gránulos de estrés realizamos la transfección de células S2 con eIF4E-1 ${ }^{\text {W117A }}$ y detectamos los SG mediante inmuno-histoquímica contra TIA-1, luego de estresar a las células con arsenito de sodio (Fig. 29, panel inferior). Encontramos que el mutante tampoco se encuentra en SG, sino que se mantiene disperso por el citoplasma. 


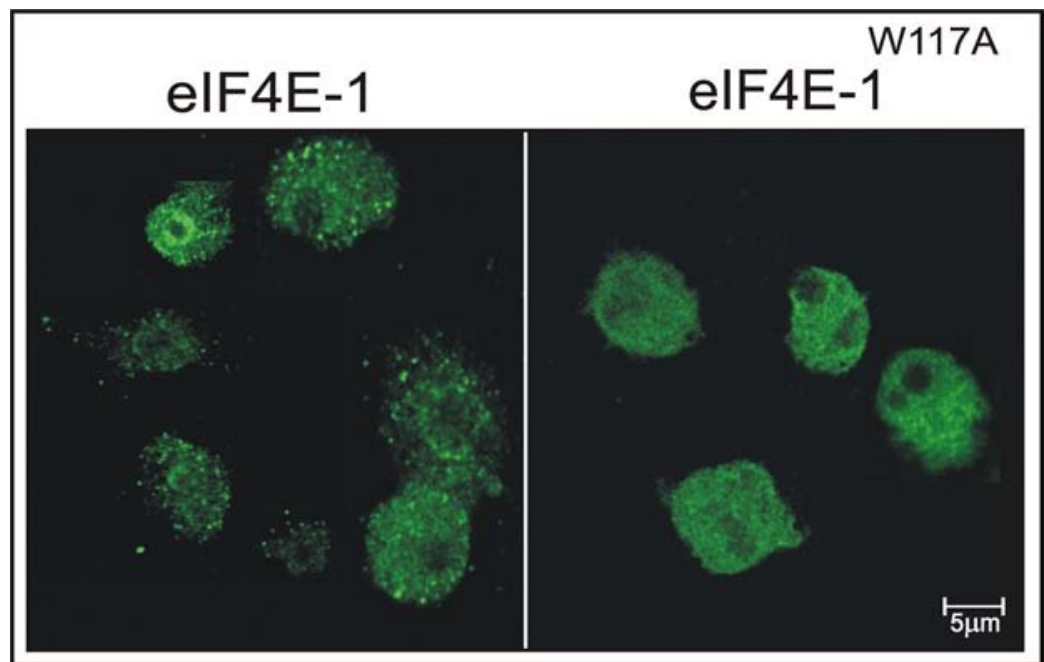

Figura 28. Transfección de células $S 2$ con pCS-eIF4E-1 y con el mutante pCS-eIF4E-1 ${ }^{\text {W117A }}$. Se detectaron con anticuerpos primario anti-Myc y secundario Cy2. Se observa que el mutante deslocaliza de gránulos citoplasmáticos.

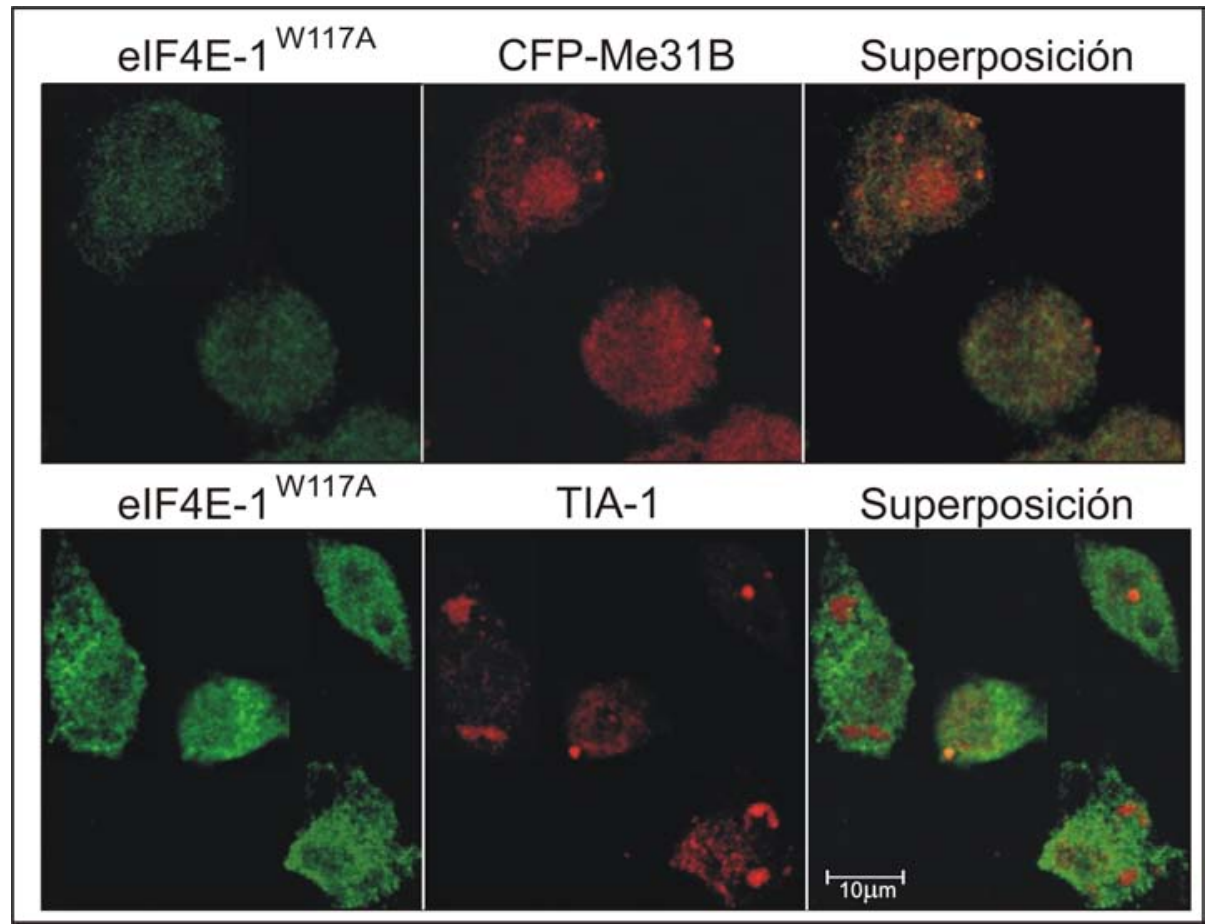

Figura 29.Panel superior: células $S 2$ transfectadas con pCS-eIF4E-1 ${ }^{\text {W117A }}$ y CFP-Me31B (como marcador de PB). Panel inferior: células S2 transfectadas con pCS-eIF4E-1 ${ }^{\mathrm{W} 117 \mathrm{~A}}$, estresadas con arsenito de sodio e inmuno-marcadas con anti-TIA-1 (Cy3, rojo) y anti-Myc (Cy2, verde) 
Se nos planteó la incertidumbre de evaluar que ocurría con otras isoformas de eIF4E al mutar este sitio. eIF4E-3 posee una sustitución en el aminoacido correspondiente al W117 de eIF4E-1. En su lugar posee una fenilalanina (F103), sin embargo en el capítulo 1 demostramos que esta isoforma se ubica en PB y en SG (Fig.12 y Fig. 30 izquierda). Por lo tanto podemos concluir que el cambio de fenilalanina por triptófano, ambos de estructura aromática evita la deslocalización de los gránulos. Sin embargo aquí mostramos que el mutante eIF4E-3 $3^{\mathrm{F} 103 \mathrm{~A}}$ se encuentra distribuído por todo el citoplasma en células S2, y no se acumula en gránulos citoplasmáticos (Fig. 30 centro) al igual que lo encontrado anteriormente para eIF4E-1.

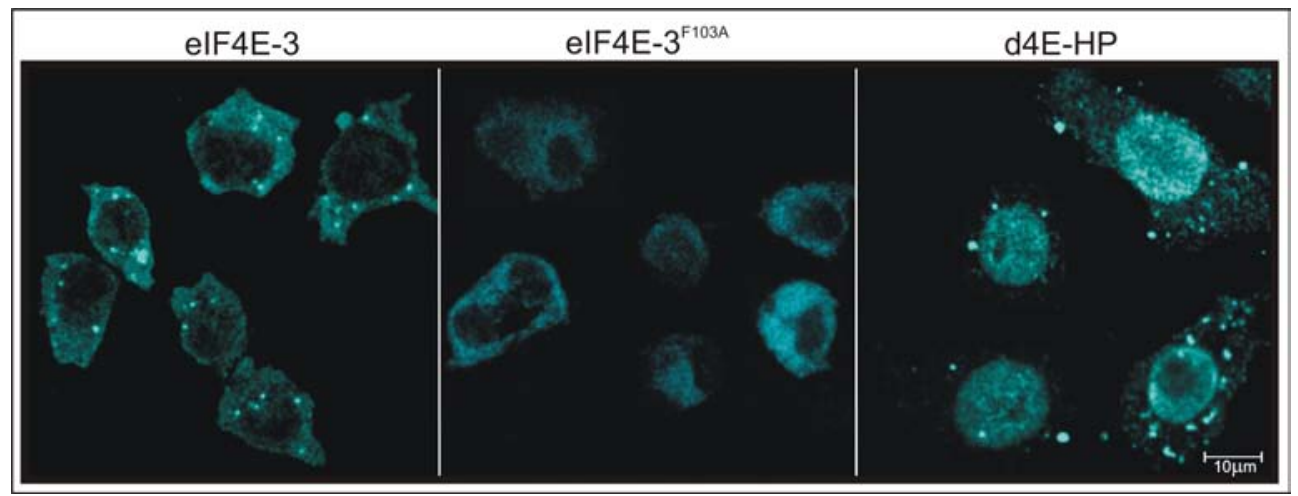

Figura 30. Transfección de células $S 2$ con CFP-eIF4E-3, con el mutante CFP-eIF4E-3 ${ }^{\text {F117A }}$ y con CFP-d4E-HP. Se observa que el mutante se deslocaliza de los gránulos.

Por lo tanto, podemos afirmar que el sitio de unión proteína-proteína de eIF4E es el responsable de su localización en gránulos citoplasmáticos. La isoforma d4E-HP posee varias sustituciones en los residuos que participan en la unión a otras proteínas, pero no tiene alterado el residuo W85 (correspondiente a W117 de eIF4E-1), y sin embargo, es encontrado en gránulos citoplasmáticos (Fig. 12 y Fig. 30 derecha). Por lo tanto, podemos concluir que es el aminoácido triptófano 117 en particular, el encargado de localizar a eIF4E en gránulos. 


\section{Discusión}

Una consecuencia importante de estos resultados es la re-evaluación de la función de eIF4E. La unión a cap es absolutamente necesaria para iniciar la traducción, pero, más importante aún, la inmovilización de eIF4E al ARNm es necesaria para llevar otros factores de traducción (De Gregorio et al. 2001).

Nuestros datos apoyan la idea de una doble función de eIF4E, por un lado su rol en la traducción que requiere la actividad de unión al cap y por otro, el reclutamiento a PB o SG, que es independiente de la actividad de unión a cap. eIF4E se encuentra en el complejo eIF4F y, a continuación se supone que debe ser removido después de la iniciación de la traducción del ARNm (Gingras et al., 1999). En este contexto, contradecimos el modelo del ARNm circularizado vía cap-4E-4G-PABP-polyA (revisado en (Derry et al., 2006)). Sin embargo, otros factores de inicio de la traducción distintos a eIF4E y proteínas de unión al ARN necesitan mantener las uniones 5'-3' después del inicio de la traducción (Svitkin et al., 2009) y podrían ser puntos clave de regulación (Zekri et al., 2009). Por lo tanto, nuestra hipótesis es que eIF4E permanece en el ARNm durante todo el proceso de traducción, aunque luego del inicio lo hace de manera independiente del cap. Por lo tanto, puede desempeñar un "papel pasivo", como un adaptador o un vínculo común después de la iniciación de la traducción para la remodelación de los complejos mRNP. Esto explicaría por qué es el único factor de la traducción que se ha detectado tanto en ARNm traduccionalmente activos como inactivos. Nuestro modelo apoya la idea de que eIF4E participa en el intercambio de factores a través de interacciones proteína-proteína, intercambiando componentes de la maquinaria de traducción por componentes de PB. Esto no excluye el papel de eIF4E en la prevención del decapping como se ha postulado previamente (Coller and Parker, 2004). Nuestro trabajo previo en eIF4E ha sugerido que existe una jerarquía de factores necesarios para ensamblado secuencial de PB (Andrei et al., 2005) en el cual, la falta de eIF4E, rck/p54 o eIF4E-T impide el reclutamiento de Dcp1, Xrn -1, CCR-4 y otros factores.

Estudios recientes han propuesto que la proteína hsp90 participa en la formación de PB y que se requiere de la presencia de eIF4E y eIF4E-T (Matsumoto et al., 2011; Suzuki et al., 2009). Se observó que cuando se inhibe la proteína hsp90 (con 
geldamicina o radicicol) se impide la formación de PB. Sin embargo, la capacidad de eIF4E de unirse al cap está intacta frente a estos tratamientos. En conjunto, la evidencia actual apoya la hipótesis de que durante la remodelación, eIF4E se mantiene en el complejo independientemente de su unión al cap; y son las interacciones proteína-proteína las encargadas de formar los PB mediante acumulación de factores. 


\section{Capítulo 3}

\subsection{Interacciones in vivo entre componentes de PB}

\subsection{1 ¿Cómo estudiar las interacciones intermoleculares?}

Desde el punto de vista clásico, la función molecular de una proteína está determinada por la acción local de una sola molécula proteica; mientras que en una visión integradora (como la que nos obliga la post-genómica) la función de la proteína se define como su conjunto de interacciones con otras moléculas, sean estas proteínas o no (Fig. 31). De la misma manera las interacciones entre proteínas en la célula se ven generalmente influenciadas por su entorno, estado de fosforilación, presencia de otras proteínas, etc.

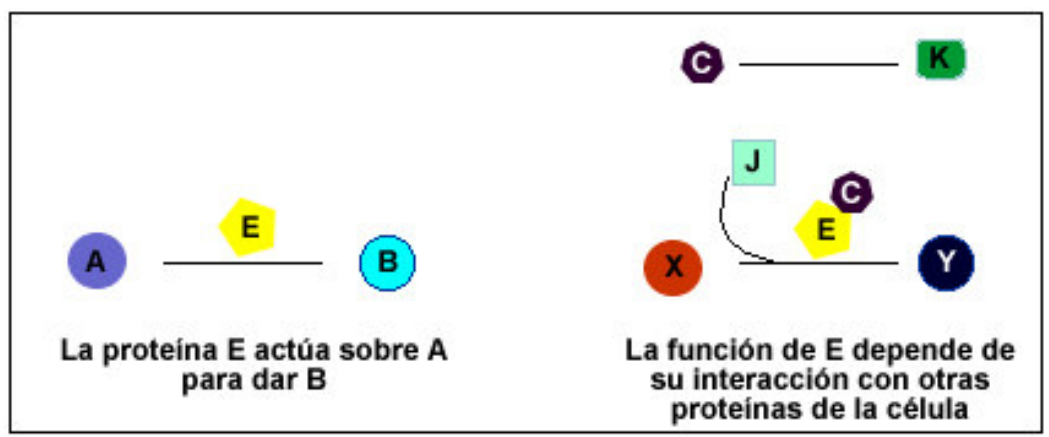

Figura 31. Esquema representativo de la función de una proteína, a la izquierda la definición clásica y a la derecha la post-genómica.

Los métodos experimentales disponibles para detectar interacciones entre proteínas tienen distintos niveles de resolución (Tabla 3) y pueden clasificarse en cuatro categorías (Xenarios and Eisenberg, 2001). La primera categoría comprende el análisis atómico, donde la interacción es detectada por métodos muy sensibles como la difracción de rayos-X (DRX) que aporta información específica sobre los átomos y residuos que participan en la interacción (Perutz et al., 1960). La segunda categoría agrupa a los métodos que detectan las interacciones binarias, por ejemplo, experimentos de doble-híbrido (Fields and Song, 1989). La tercera categoría agrupa a los métodos de detección de complejos mediante técnicas de co-purificación (Elion, 2001), como la cromatografía de afinidad o la co-inmunoprecipitación (acopladas a 
espectrometría de masas (Blackstock and Weir, 1999) para identificar los componentes de los complejos). La cuarta categoría comprende bioensayos realizados a escala celular, por ejemplo, la proliferación celular estimulada por la interacción ligandoreceptor.

Cada uno de los método tienen sus ventajas y desventajas, la elección de uno de ellos depende del sistema de estudio y de los resultados buscados. En muchos casos es común la presencia de resultados falsos positivos y falsos negativos. Por lo tanto, muchas veces se determina la interacción de proteínas mediante la utilización de más de un método.

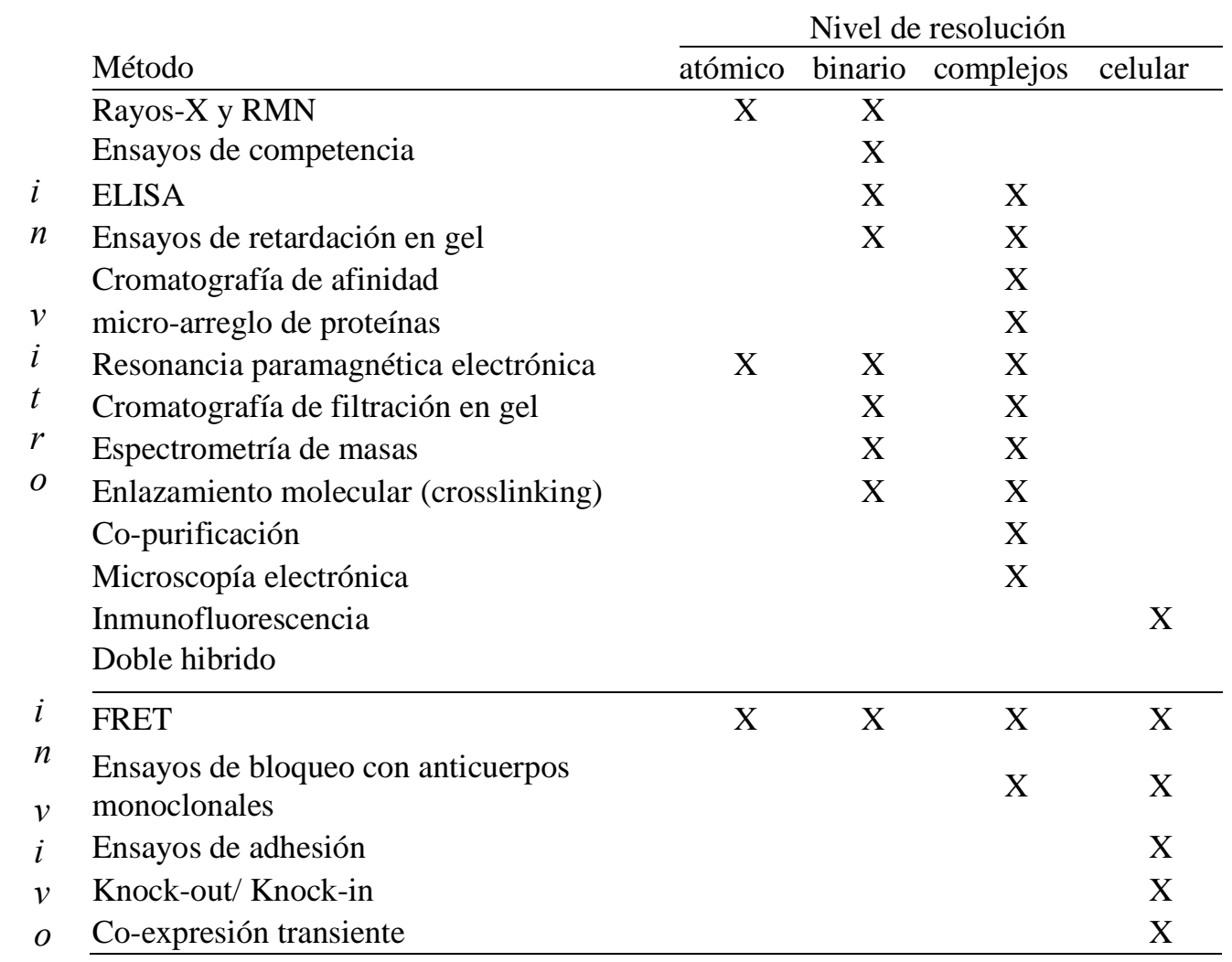

Tabla 3. Métodos para detectar interacciones entre proteínas. FRET: energía fluorescente transferida por resonancia; ELISA: ensayo enzimático de inmunoabsorción; RMN: resonancia magnética nuclear; Knock-out: experimentos de deleción de genes.

Los métodos basados en la purificación de complejos son muy útiles para estudiar complejos multiproteicos, pero no permiten evaluar la interacción entre dos componentes particulares. Una de las ventajas de estos métodos es que al trabajar con sistemas in vivo, las proteínas estudiadas tendrán además de su estructura nativa, las 
modificaciones post traduccionales, que muchas veces son necesarias para su interacción con otros componentes. Asimismo, se evita la detección de interacciones no fisiológicas, que ocurren cuando se estudian dos proteínas in vitro. Una desventaja de estas técnicas es que no permiten la detección de interacciones débiles o de rápida cinética de disociación. Es posible que las proteínas que interactúan débilmente estén en el complejo dentro de la célula, pero se disocian después de la lisis celular y/o de la purificación por afinidad. Otro inconveniente es que el lavado de las muestras para eliminar proteínas contaminantes con soluciones salinas puede también disociar una unión de baja afinidad. El crosslinking de proteínas se utiliza para "congelar" y capturar las interacciones transitorias y/o de baja afinidad. Por ejemplo, la técnica TAP (Forler et al., 2003; Rigaut et al., 1999) se combinó recientemente con crosslinking mediante formaldehído para la detección de interacciones transitorias proteínaproteína in vivo (Jones and Thornton, 1996).

Dentro de los métodos que utilizan la biología molecular, el de doble híbrido es uno de los más utilizados. Se basa en el hecho de que muchos factores de transcripción eucariotas, tales como el potenciador de levaduras Gal4, se componen de dos dominios funcionalmente distintos que median la activación de la transcripción y la unión al ADN respectivamente. Cada uno de estos dominios se fusiona, por técnicas de biología molecular, a una de las proteínas a estudiar. Luego las proteínas son expresadas en un sistema heterólogo (levaduras) y la interacción es detectada indirectamente por expresión de un reportero. Estos ensayos son relativamente fáciles de llevar a cabo, son de bajo costo, requieren poca puesta a punto, y se realizan en sistemas in vivo. Las desventajas son que sólo se pueden estudiar pares de proteínas y además aproximadamente el $50 \%$ de los resultados son falsos positivos. Por lo tanto se propone verificar la interacción por otro método. Por otro lado, las interacciones entre las proteínas de mamíferos que dependen de las modificaciones post traduccionales y/o que están mal plegadas en las levaduras no puede ser estudiadas. Sin embargo, ya han sido desarrollados sistemas de doble híbrido en mamíferos. Asimismo, existen sistemas de triple híbrido que permiten estudiar triadas de proteínas. 


\subsubsection{Microscopía del interactoma: la bioquímica celular in vivo.}

Para contrarrestar las desventajas de los métodos clásicos, se han desarrollado técnicas más avanzadas que utilizan microscopía (Verveer and Bastiaens, 2008; Wouters et al., 2001). La localización de las proteínas en la célula puede ser detectada con el uso de anticuerpos marcados o mediante la expresión de proteínas fluorescentes quimeras (Giepmans et al., 2006). La detección simultánea de dos o más especies puede ser utilizada para determinar interacciones (Bolte and CordeliÈRes, 2006; French et al., 2008). Sin embargo, el hecho de que las imágenes de las diferentes moléculas muestren co-localización en el mismo píxel no implica que estén interactuando. Debido al límite de difracción, en un microscopio óptico (es un filtro de paso bajo) la conversión de fuentes puntuales de luz en la muestra se convierten en imágenes borrosas en el detector (Heintzmann and Ficz, 2007). Moléculas muy lejanas entre sí (en el sentido de interacción) pueden aparecer juntas en la imagen, dando señales de falsos positivos. En microscopía convencional (Fig. 32.A) y microscopía confocal (Fig. 32.B), el área de observación en el plano focal se define principalmente por la apertura numérica del sistema. La principal diferencia está en la resolución en el eje óptico: la microscopía confocal rechaza la luz fuera de foco, mientras que la microscopía de campo no lo hace. El efecto resultante es que las señales de las tres partículas ilustradas co-localizan en la microscopía clásica, pero sólo la amarilla y roja lo harán en microscopía confocal. El volumen confocal $(\sim 1 \mu \mathrm{m} 3=1 \mathrm{FL})$ es todavía mucho mayor que el rango de interacción. Los avances en microscopía de luz han aportado diferentes métodos para romper el límite de difracción (Betzig et al., 2006; Hein et al., 2008; Medda et al., 2006) con buenos resultados. Sin embargo, su uso en la biología es todavía limitado, especialmente en los sistemas altamente dinámicos, como las células vivas. FRET se basa en una interacción foto-física con una escala de longitud mucho más corta que el volumen confocal (Fig. 32.C). Debido a ello, es un método ampliamente utilizado para estudiar las interacciones proteína-proteína. Esta basado en la transferencia de energía entre dos cromóforos, donde la energía de emisión de un cromóforo (donante) se solapa con la energía de excitación de una segunda molécula (aceptor). Se pueden estudiar interacciones adn-proteína, proteínaproteína y cambios conformacionales en las proteínas. 


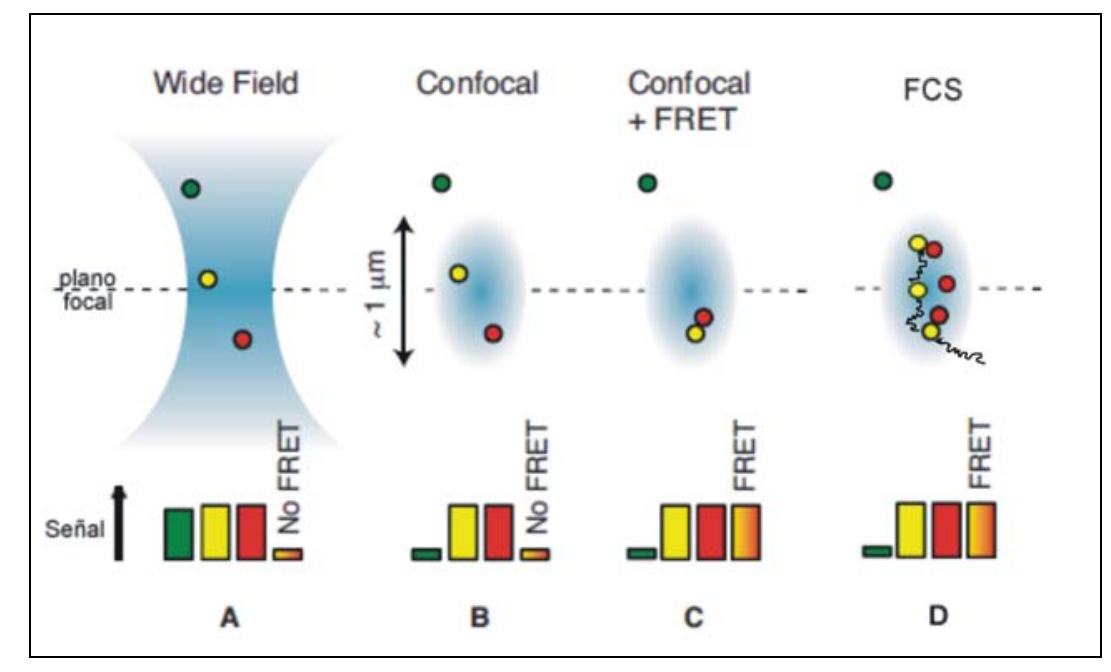

Figura 32. Comparación de los sistemas de microscopía y de sus diferentes lecturas para el estudio de las interacciones entre proteínas. El volumen de detección se representa en azul, y tres puntos (verde, amarillo y rojo) representan las proteínas objeto de estudio. (A) En microscopía de campo, el volumen de detección se extiende a lo largo de la dirección axial produciendo una señal significativa para las moléculas incluso fuera del plano focal. (B) En la microscopía confocal, las partículas de luz que viene de fuera de foco (verde) son rechazadas. Sin embargo, debido al tamaño del volumen confocal, dos partículas que no interactúan aparecerán como co-localización. Contrariamente a esto, la fuerte dependencia con la distancia de FRET (C) sólo dará una señal positiva cuando las partículas interactúan. En FCS (fluorescente correlation spectroscopy) se mide la fluctuación de la señal fluorescente en el tiempo (D), la misma varía si la molécula fluorescente esta interaccionando con otra molécula.

Por otro lado, FCS (Fluorescence Correlation Spectroscopy) es una técnica para el estudio de los movimientos moleculares y de interacciones, donde se mide la fluctuación de la señal fluorescente respecto al tiempo (Fig. 32.D). Las fluctuaciones de fluorescencia proporcionan información acerca de las concentraciones y los parámetros de difusión de una partícula fluorescente. Dado que la difusión es directamente dependiente de la masa de la partícula, cualquier aumento en la masa de una biomolécula, por ejemplo, como resultado de una interacción con una segunda molécula, es fácilmente detectada como un aumento del tiempo de difusión de la partícula. Otra técnica común es PCA (ensayo de complementación de fragmentos de proteína) utiliza dos fragmentos derivados de una sola proteína fluorescente (por ejemplo GFP, YFP), basada en la idea de que algunas proteínas fluorescentes o 
factores de transcripción son modulares y que su actividad puede ser reconstituida cuando los dos dominios de la proteína están en estrecha proximidad entre sí.

Como se mencionó anteriormente, la técnica de FRET permite estudiar interacciones proteína-proteína en células in vivo. Detecta interacciones binarias de forma directa. Al ser una técnica que permite estudiar las interacciones in vivo, responde dinámicamente a las modificaciones post traduccionales, y asimismo la interacción puede darse en cualquier lugar de la célula. En esta tesis se eligió FRET para evaluar la interacción entre componentes de gránulos citoplasmáticos debido a las ventajas mencionadas y a la experiencia previa en el estudio de interacciones en PB (Andrei et al., 2005). El detalle teórico y metodológico será discutido a continuación.

\subsubsection{Principio de FRET}

Se llama FRET (Fluorescence/Förster Resonance Energy Transfer) a la transferencia de energía no radiante desde un fluoróforo donor excitado hacia un fluoróforo aceptor (Förster, 1948; Stryer, 1978). Como resultado de este fenómeno la emisión de fluorescencia de la molécula aceptora se ve reforzada por la excitación de la molécula donora, esto va acompañado a su vez, de una reducción en la emisión de las moléculas donantes (Fig. 33). La eficiencia de transferencia de energía es inversamente proporcional a la sexta potencia de la distancia molecular entre el donor y el aceptor.

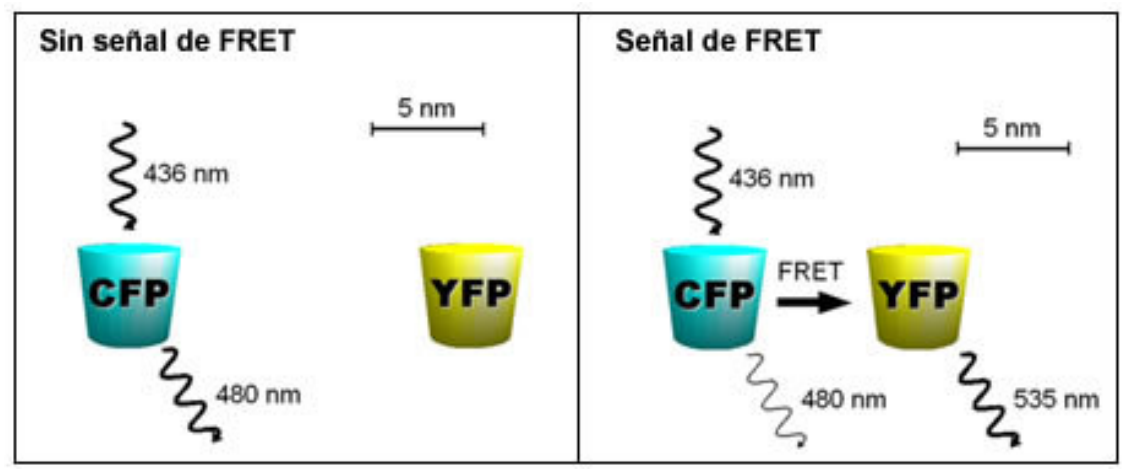

Figura 33. Esquema que muestra ausencia o existencia de FRET, dependiendo de la distancia a la que se encuentran las moléculas de los fluoróforos donor y aceptor. 
La tasa de energía transferida del donor al aceptor esta dada por:

$$
\kappa_{T}(r)=\frac{1}{\tau_{D}}\left(\frac{R_{0}}{r}\right)^{6},
$$

donde $\tau_{D}$ es el tiempo de decaimiento del donor en ausencia del aceptor, $R_{0}$ es la distancia de Förster, y $r$ es la distancia entre la molécula de donor y aceptor. Por lo tanto, la tasa de transferencia es igual a la tasa de decaimiento del donor cuando la distancia entre donor y aceptor es igual a la distancia de Förster $\left(r=R_{0}\right)$, en este caso la eficiencia de FRET es del 50\% (Fig. 34).

Por lo tanto si definimos la eficiencia de FRET como la energía transferida del donor al aceptor sobre la energía total absorbida por el donor:

$$
E=\frac{\kappa_{T}}{\kappa_{T}+\kappa_{D}}=\frac{R_{0}{ }^{6}}{R_{0}{ }^{6}+r^{6}},
$$

podemos apreciar la fuerte dependencia con la distancia entre donor y aceptor a distancias cercanas a $R_{0}$.

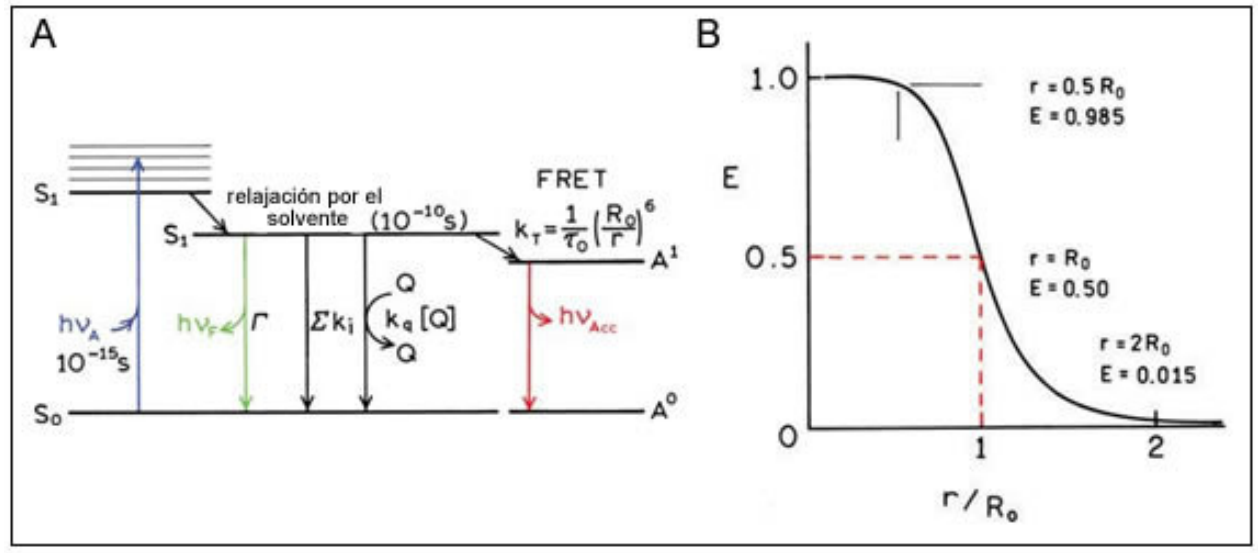

Figura 34. A. Diagrama de Jablonski, se muestra la disminución en la intensidad de fluorescencia generada por colisión y por transferencia de energía fluorescente por resonancia (FRET).El término $\Sigma$ ki se utiliza para representar caminos no radiactivos hacia su estado fundamental. B. Dependencia de la eficiencia de transferencia de energía en función de la distancia. $\mathrm{R}_{0}$ es la distancia de Förster.

La tasa de transferencia de energía entre un donor y un aceptor separados por una distancia $r$ viene dada por: 


$$
\kappa_{T}(r)=\frac{Q_{d} \kappa^{2}}{\tau_{D} r^{6}}\left(\frac{9000(\ln 10)}{128 \pi^{5} N n^{4}}\right) \int_{0}^{\infty} F_{D}(\lambda) \varepsilon_{A}(\lambda) \lambda^{4} d \lambda
$$

$Q_{D}$ es el rendimiento cuántico del donor en ausencia del aceptor

$n \quad$ es el índice de refracción del medio

$N$ es el número de Avogadro

$r$ es la distancia entre el donor y el aceptor

$\tau_{D}$ es el tiempo de vida del donor en ausencia del aceptor

$\kappa^{2}$ es un factor que describe la orientación espacial de los dipolos del donor y del aceptor. Generalmente es equivalente a $2 / 3$, valor que asume una dinámica aleatoria.

$\int_{0}^{\infty} F_{D}(\lambda) \varepsilon_{A}(\lambda) \lambda^{4} d \lambda$ es la integral de overlap $J(\lambda)$ que expresa el grado de solapamiento espectral entre el espectro de emisión del donor y el espectro de absorción del aceptor.

La eficiencia de la transferencia de energía es comúnmente medida usando la intensidad de fluorescencia del donor en ausencia $\left(F_{D}\right)$ y en presencia $\left(F_{D A}\right)$ del aceptor: $E=1-\frac{F_{D}}{F_{D A}}$, también puede utilizarse el tiempo de vida del donor en las mismas condiciones $E=1-\frac{\tau_{D}}{\tau_{D A}}$. Es muy importante recordar que estas dos últimas ecuaciones son válidas para el caso de que exista una distancia fija entre el donor y el aceptor.

Resumiendo las condiciones necesarias para que FRET ocurra podemos destacar tres puntos fundamentales:

A. Las moléculas involucradas deben ser un par FRET: debe existir superposición entre el espectro de emisión del donor y el espectro de excitación del aceptor (Fig. 35.A) 
B. Las moléculas deben estar en estrecha proximidad entre sí: para que la transferencia de energía sea posible la distancia entre donor y aceptor debe estar en el rango de 1-10 nm (Fig. 35.B).

C. Las moléculas deben estar correctamente orientadas: la orientación de las moléculas en el espacio debe ser aquella que permita la transferencia de energía entre los dipolos. Esta característica hace que la técnica pueda dar resultados falsos negativos (Fig. 35.C).

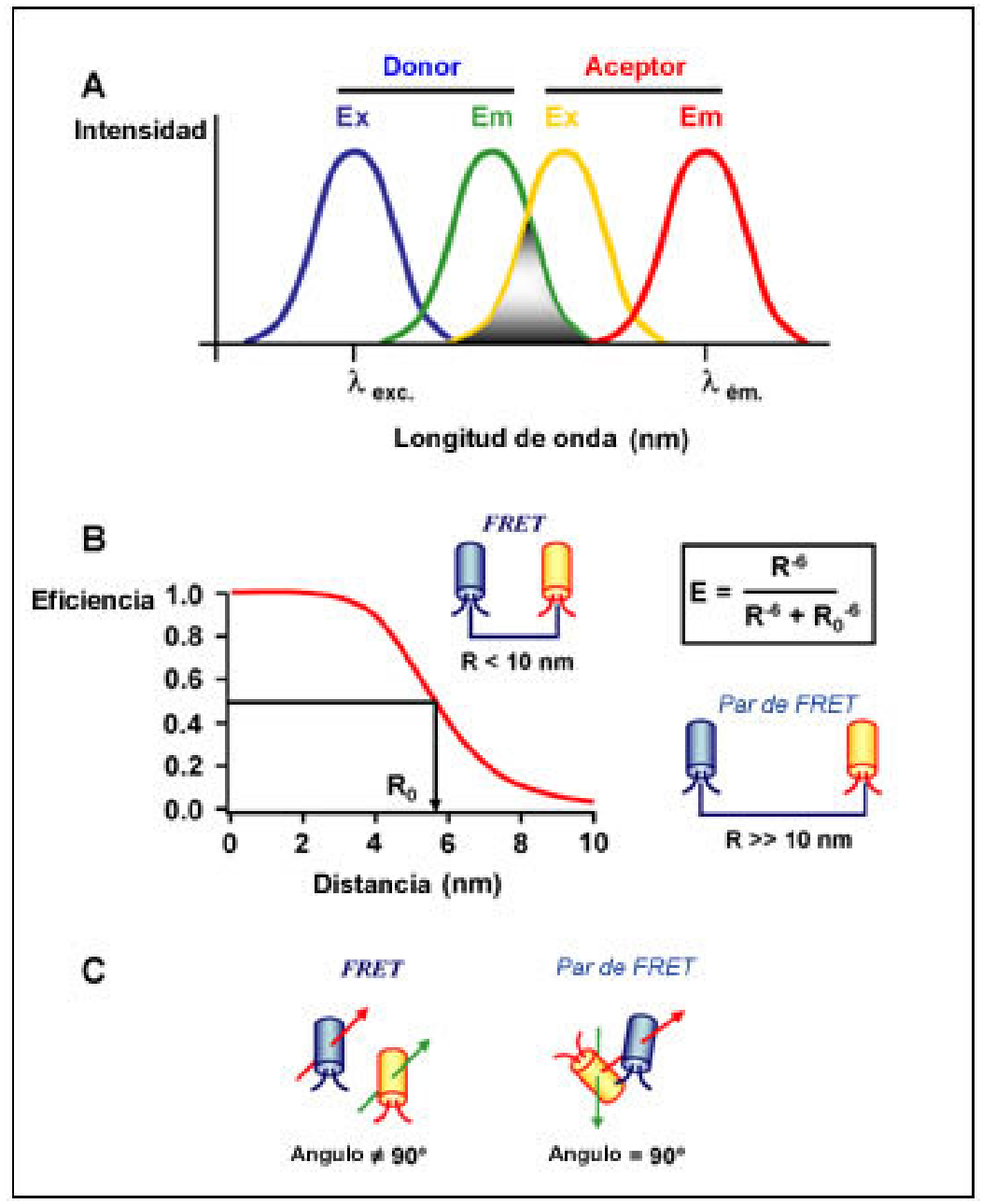

Figura 35. Resumen de las características que deben cumplir los fluoróforos para que ocurra FRET.

Debido a que el fenómeno de FRET es un proceso estocástico, la falta de detección de FRET en experimentos de laboratorio no necesariamente descarta las interacciones 
entre las moléculas, sólo establece un límite inferior de sensibilidad en la detección de esas interacciones.

\subsubsection{FRET para ver interacciones entre moléculas en células.}

Existen varias técnicas mediante las cuáles se puede calcular la eficiencia de FRET (Tabla 4), elegir una de ellas depende del sistema de estudio y de los objetivos que se quieren evaluar (Jares-Erijman and Jovin, 2003).

La perdida de energía de estado excitado a través de FRET significa que el rendimiento cuántico de los donantes disminuye (quenching), ya que, menos fotones son emitidos directamente. Al mismo tiempo, la molécula receptora es excitada a través de FRET y por lo general emite parte de esa energía en forma de fotones (emisión sensibilizada). Por lo tanto, una disminución del espectro del donante junto con un aumento del espectro del aceptor revela la ocurrencia de FRET. Medir el espectro completo en un microscopio es un reto y requiere mucho tiempo, pero el mismo resultado se puede lograr mediante la medición de algunas longitudes de onda. En su forma más simple, se trata de excitar el fluoróforo donor, y medir la emisión del donor y del aceptor. Gráficamente la relación de los dos en cada píxel de la imagen muestra la ocurrencia de FRET. Conceptualmente simple, esta fue la primera técnica empleada en células individuales (Adams et al., 1991) y sigue siendo ampliamente utilizada, ya que, es muy efectiva para una gran cantidad de sensores de FRET que consisten en fluoróforos unidos físicamente.

Por otro lado, el método del cociente (ratio imaging) es de uso limitado si las concentraciones relativas de donante y aceptor varían dentro de la célula o cambian con el tiempo, ya que esto afecta la relación de fluorescencia donante/fluorescencia aceptor. El método de emisión sensibilizada (sensitized emisión) hace una corrección de la interferencia mediante el uso de mediciones específicas de la fluorescencia del donor y del aceptor (Gordon et al., 1998; Nagy et al., 1998). Este enfoque ha sido ampliamente utilizado, pero sufre de una alta sensibilidad al ruido, y por lo tanto, los resultados pueden ser difíciles de interpretar. Otra alternativa, en lugar de evaluar la intensidad del aceptor como medida de FRET, es utilizar medidas de la fluorescencia 
del donor. El método de fotoblanqueo del aceptor (aceptor photobleaching) mide la disminución de emisión de los donantes debida a la transferencia de energía al aceptor, realizando una medida de la emisión del donor en ausencia de dicha transferencia mediante el fotoblanqueo del aceptor (Bastiaens et al., 1996). Este método es fiable, pero inadecuado para seguir los procesos dinámicos en células vivas.

\begin{tabular}{|c|c|c|c|}
\hline Método & Principio & Aplicación & Desventaja \\
\hline $\begin{array}{l}\text { Emisión } \\
\text { sensibilizada }\end{array}$ & $\begin{array}{l}\text { Emisión del aceptor al excitar } \\
\text { el donor }\end{array}$ & $\begin{array}{c}\text { Para fluoróforos } \\
\text { unidos } \\
\text { físicamente }\end{array}$ & Alta sensibilidad al ruido \\
\hline $\begin{array}{l}\text { Relación de } \\
\text { imágenes }\end{array}$ & $\begin{array}{l}\text { Relación de la señal } \\
\text { donor/aceptor }\end{array}$ & $\begin{array}{l}\text { Para sensores } \\
\text { intramoleculares }\end{array}$ & $\begin{array}{c}\text { Depende de la } \\
\text { concentración relativa del } \\
\text { donor y del aceptor }\end{array}$ \\
\hline $\begin{array}{l}\text { Fotoblanqueo } \\
\text { del aceptor }\end{array}$ & $\begin{array}{c}\text { Disminución de emisión del } \\
\text { donor por transferencia al } \\
\text { aceptor }\end{array}$ & $\begin{array}{l}\text { Para una amplia } \\
\text { gama de } \\
\text { sensores }\end{array}$ & $\begin{array}{l}\text { No se pueden evaluar } \\
\text { procesos dinámicos }\end{array}$ \\
\hline FLIM & $\begin{array}{l}\text { Tiempo de vida media del } \\
\text { estado excitado }\end{array}$ & $\begin{array}{l}\text { Resultados } \\
\text { cuantitativos }\end{array}$ & $\begin{array}{c}\text { El tiempo de vida media } \\
\text { del donor debe ser mono } \\
\text { exponencial }\end{array}$ \\
\hline
\end{tabular}

Tabla 4. Resumen de los métodos más utilizados para medir FRET

FRET modifica el tiempo de vida media del estado excitado, por lo tanto, se puede utilizar como sensor el tiempo de vida fluorescente del donor y del aceptor. FLIM (Fluorescence Lifetime Imaging) utiliza este concepto para la medida de FRET, su uso ha aumentado mucho impulsado por su fiabilidad y posibilidades cuantitativas (Bastiaens and Squire, 1999; Gadella Jr et al., 1993). La fiabilidad de FLIM deriva del hecho de que la vida de fluorescencia es independiente de la concentración del fluoróforo y de la longitud de trayectoria de la luz, pero depende directamente de las reacciones en el estado excitado, como FRET. FLIM se utiliza especialmente cuando se requieren resultados cuantitativos.

En esta tesis se utilizó la técnica de FRET con el objetivo de medir interacciones entre proteínas celulares en PB. Para logar este objetivo se eligió el método de medida de fotoblanqueo del aceptor ya que es muy fiable, fácil de implementar y no necesita controles externos (el fotoblanqueo es un control interno). Se calcula la eficiencia de FRET en base al aumento en la emisión del donor luego del fotoblanqueo del aceptor. 
Para esto se procedió de la siguiente manera:

1- Se excita al donor y se mide su emisión.

2- Se fotoblanquea el aceptor (>90\%).

3- Se excita al donor y se mide su emisión.

La eficiencia de FRET calculada por este método es una eficiencia aparente, ya que, la intensidad de fluorescencia obtenida depende de las concentraciones del donor y del aceptor, por lo tanto: $E_{\text {aparente }}=E \frac{[D A]}{[D]+[D A]}$, donde $[D]$ es la concentración de moléculas de donor libre y $[D A]$ es la concentración del donor que está interaccionando con el aceptor.

\subsubsection{Diseño de los pares de FRET y elección de los fluoróforos.}

Como se mencionó en secciones anteriores es necesario que el par de fluoróforos elegido para armar las proteínas de fusión fluorescentes cumpla con la condición de solapamiento espectral entre la emisión del donor y la excitación del aceptor.

En este caso se eligió el par CFP (Cyan Fluorescent Protein) y YFP (Yelow Fluorescent Protein) cuyos espectros cumplen dicha condición (Fig. 36).

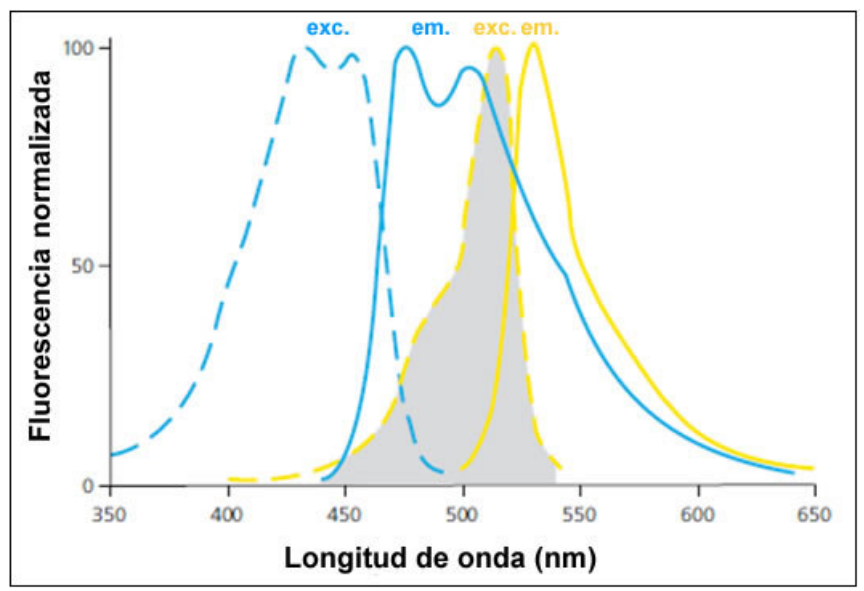

Figura 36. Solapamiento espectral (en gris) entre el espectro de emisión normalizado del donor CFP (línea celeste) y el espectro de excitación normalizado del aceptor YFP (línea amarilla discontinua).

Un aspecto importante a tener en cuenta para la elección de los fluoróforos del par es el set de láseres y filtros con los que disponemos para realizar los experimentos. Por 
lo tanto, simultáneamente a la elección de los fluoróforos hay que tener en cuenta, si se poseen o no, los láseres y filtros adecuados para poder detectar cada uno independientemente. En particular para el par elegido se utilizó el esquema de láser y filtros que se muestra en la figura 37.

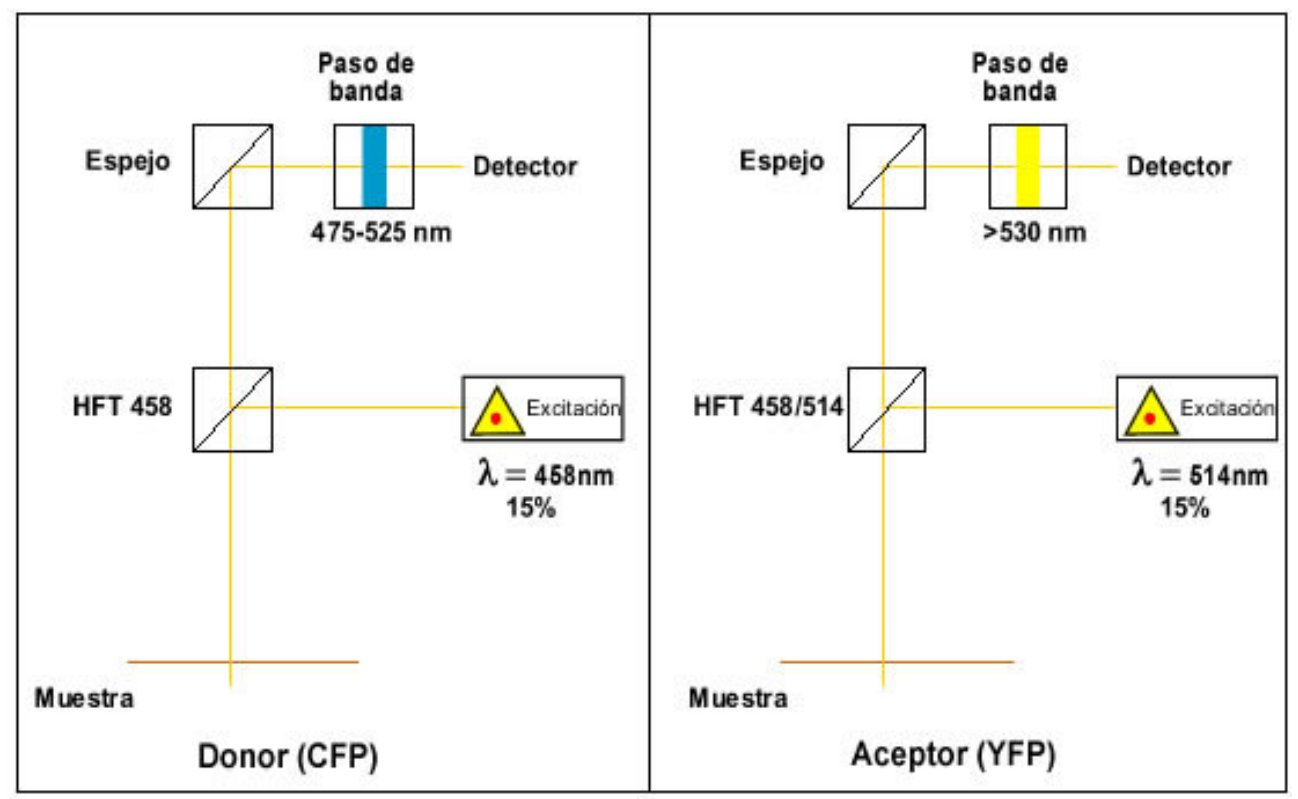

Figura 37. Láser y filtros utilizados para excitar y detectar independientemente al donor y al aceptor.

Las proteínas de fusión se realizaron por clonado en los vectores pECFP-C1 y pEYFP-C1 (Clontech), debido a que se encontró en bibliografía que esta conformación de las moléculas permite la transferencia de energía (Andrei et al., 2005), ver materiales y métodos para mas detalle.

\subsubsection{Establecimiento de parámetros experimentales}

Si bien la técnica de FRET in vivo ha sido usada en cultivos celulares, al inicio de esta tesis no había ninguna referencia de su uso en células de Drosophila. Es por eso que se debieron establecer los parámetros experimentales para el sistema. Durante la última fase de esta tesis fue publicado el uso de FRET en células S2 para el análisis de proteínas de membrana (Almudi et al., 2010). De todos modos, en esta tesis se presenta el primer estudio de interacciones proteicas en el citoplasma de células S2. 
Se comprobó, como parte de los controles físicos, que el fotoblanqueo del aceptor no altere la emisión de donor. Para esto se realizaron, transfecciones de células HeLa con la proteína de fusión CFP-rck/p54, 48 hs post-transfección las células se fijaron y se evaluó la fluorescencia después de la excitación con el láser de 514 nm (longitud de onda de excitación del aceptor) al 100\% de intensidad en una región seleccionada. Paralelamente hay que garantizar que el tratamiento produzca un fotoblanqueo del aceptor $\geq 90 \%$ para asegurarnos, de esta manera, que las medidas de FRET sean representativas y no generen resultados falsos negativos por esta causa. Para esto se transfectaron células con YFP-eIF4E y se procedió como en el caso anterior. Se analizaron diferentes tiempos de tratamiento, desde 1 a 5 minutos. Observamos que no se ve alterada la emisión del donor después de 3 minutos de tratamiento, y en la mayoría de los casos se observó un porcentaje de fotoblanqueo del aceptor mayor al 90\% (Fig. 38). Los otros tiempos analizados no mostraron una buena correlación entre el efecto sobre el donor y el aceptor (resultados no mostrados).

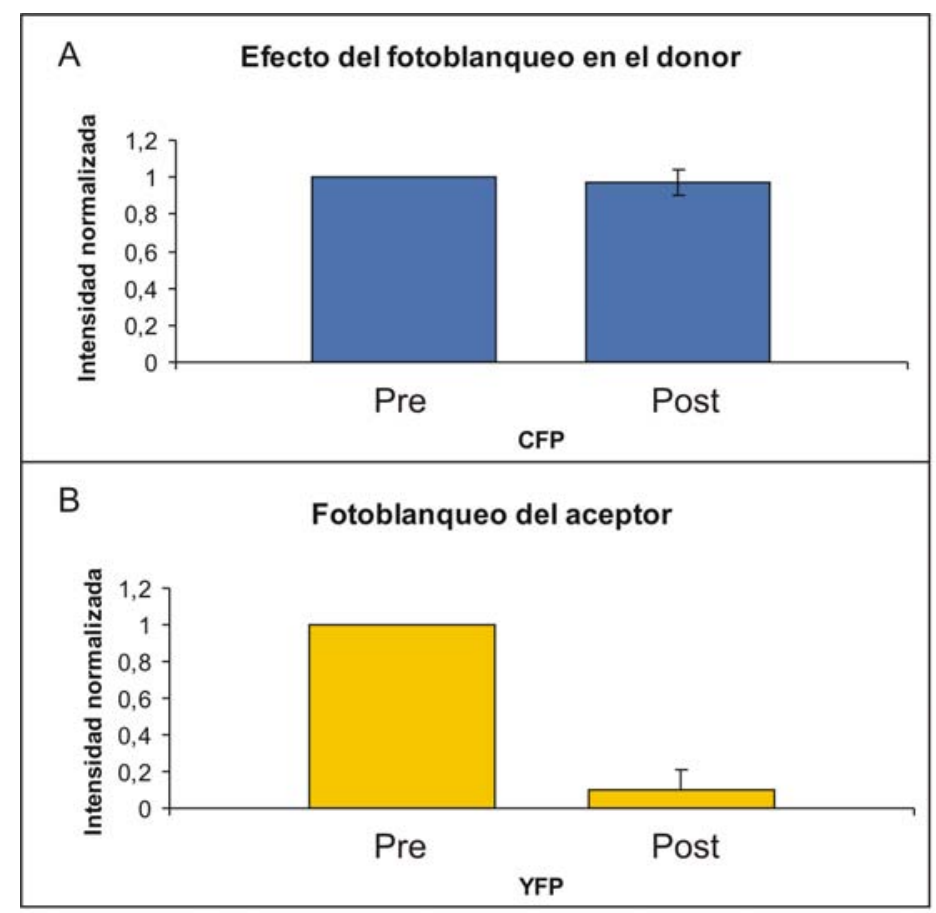

Figura 38. A. El fotoblanqueo del aceptor no produce alteración significativa sobre la intensidad de fluorescencia del donor. B. El fotoblanqueo del aceptor produce una disminución en su intensidad de fluorescencia > 90\%. (Pre: medida de intensidad de fluorescencia previa al fotoblanqueo del aceptor. Post: medida de intensidad de fluorescencia posterior al fotoblanqueo del aceptor). 
Asimismo, debemos demostrar que el sistema es capaz de detectar FRET, y de discernir correctamente entre un resultado positivo y uno negativo. Para esto utilizamos pares de proteínas previamente analizados (Andrei et al., 2005). Como control positivo se utiliza el par YFP-eIF4E y CFP-rck/p54, y como control negativo YFP-rck/p54 y CFP-eIF4E-T. Con estos pares de proteínas, se transfectaron células HeLa, a las $48 \mathrm{hs}$ fueron fijadas y posteriormente analizadas en el microscopio confocal de fluorescencia. Se seleccionaron las regiones de interés (PB) en cada célula sobre las cuáles se realizaron medidas de intensidad de fluorescencia del donor previa $\mathrm{y}$ posterior al fotoblanqueo del aceptor. Encontramos que existe una eficiencia aparente de FRET de aproximadamente $23 \%$ para el control positivo (Fig. 39). Es importante mencionar que existe una gran variabilidad en las medidas debido a que la eficiencia de FRET cambia dependiendo la región analizada en base a como sea la orientación de las moléculas en la misma. Es importante indicar que en los ensayo de FRET tiene validez un resultado positivo más que el valor absoluto del mismo (JaresErijman and Jovin, 2003).

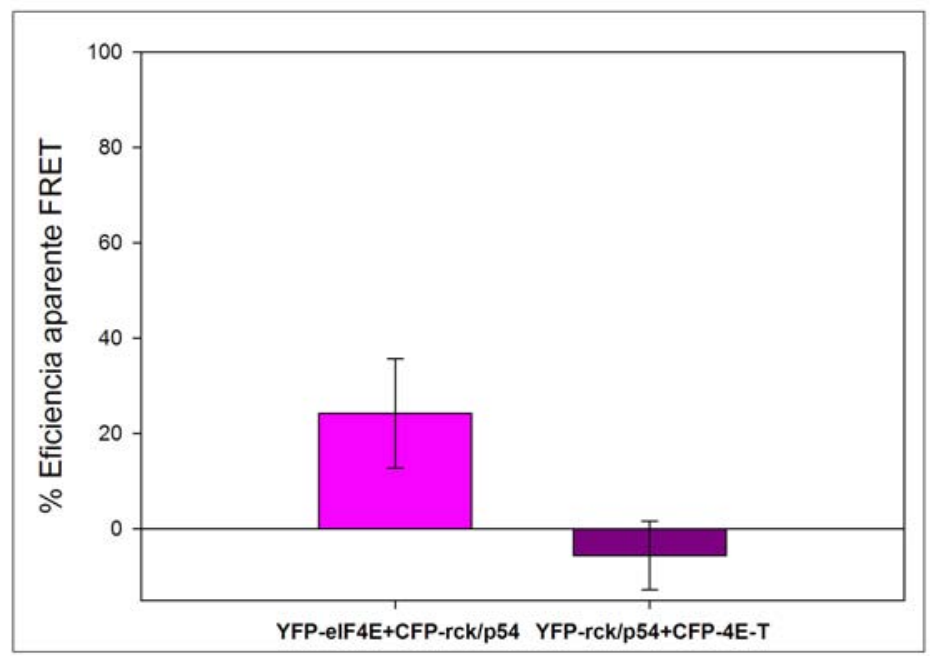

Figura 39. Control positivo (YFP-eIF4E/CFP-rck/p54) y negativo (YFP-rck/p54/CFP-eIF4E-T) de los ensayos de FRET. Se observa que el control positivo da una eficiencia aparente de FRET que varía entre un $15-35 \%$, mientras que el control negativo da resultados despreciables cercanos a cero. 
Los sucesivos experimentos de FRET se realizaron por lo tanto, con el siguiente protocolo:

1- Se transfectaron las células con el par de proteínas de fusión a evaluar.

2- Se fijaron las células a las 48 hs y se montaron en mowiol.

3- Se buscaron las células al microscopio que posean buena señal para ambos fluoróforos y se seleccionaron las regiones de interés a estudiar (los PB).

4- Se realizó una medida de intensidad del donor $\left(\mathrm{I}_{\mathrm{D}}\right)$.

5- Se excitó la muestra en las regiones de interés por 3 min con el láser de 514 nm al $100 \%$.

6- Se realizó una segunda medida de la intensidad del donor $\left(\mathrm{I}_{\mathrm{D} 0}\right)$.

7- Se calculó la eficiencia aparente de FRET como $\mathrm{E}_{\mathrm{ap}}=\left(\mathrm{I}_{\mathrm{D} 0}-\mathrm{I}_{\mathrm{D}}\right) / \mathrm{I}_{\mathrm{D} 0}$.

Paralelamente se midió la intensidad del aceptor para confirmar que se produzca un fotoblanqueo $\geq 90 \%$.

\subsection{3 eIF4E interacciona con Me31B y con Lsm-1 en PB en células S2 de Drosophila melanogaster.}

Evaluamos si las proteínas Me31B y eIF4E interaccionan entre sí en PB en células S2. Encontramos que ambas proteínas interaccionan entre sí con una eficiencia de aproximadamente $25 \%$ para el caso de eIF4E-3 y de 36\% para eIF4E-2 (Fig.40.A). En la figura 40.B se muestra, como ejemplo, el perfil de intensidad de fluorescencia del donor a través de un PB de una célula analizada (flecha roja), previo y posterior al fotoblanqueo del aceptor en la región de interés. Se aprecia un aumento en la intensidad luego del fotoblanqueo. En la imagen de la célula analizada, se observa claramente que la intensidad de fluorescencia del aceptor disminuye en los gránulos citoplasmáticos luego del fotoblanqueo.

El hecho de que estas dos proteínas interaccionen entre sí en células de Drosophila está indicando un cierto grado de conservación funcional, ya que las proteínas ortólogas en humanos también interaccionan entre sí en PB. Por lo tanto, puede decirse que ambas proteínas cumplen alguna función en el remodelamiento de mRNP para la cuál es necesaria dicha interacción. 
Debido a que eIF4E es el único factor presente en mRNP activos que se encuentra en $\mathrm{PB}$, podría especularse que Me31B podría estar involucrada en las primeras etapas de transición de un ARNm traduccionalmente activo hacia uno inactivo en PB.

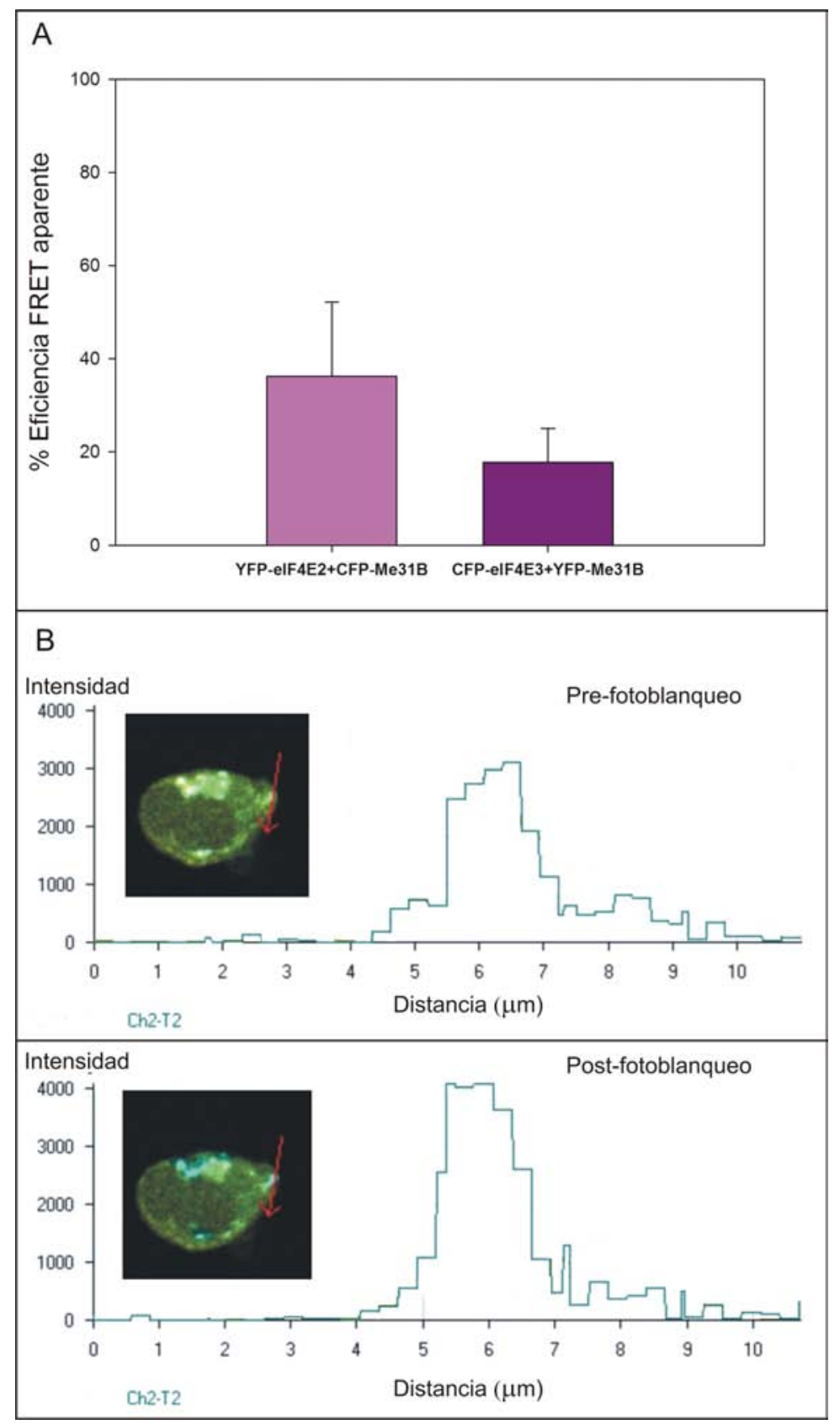

Figura 40. Eficiencias de FRET de los pares YFP-eIF4E-2/CFP-Me31B (25-45\%) y CFP-eIF4E3/YFP-Me31B (15-30\%). Se muestra la imagen de una célula analizada y el perfil de intensidad de fluorescencia del donor a traves de la flecha roja, previo y posterior al fotoblanqueo del aceptor. 
De la misma manera evaluamos si eIF4E interacciona con la proteína Lsm-1 en PB en células S2. En este caso encontramos una eficiencia aparente de FRET de aproximadamente $35 \%$ para eIF4E-3 y de $25 \%$ para eIF4E-2 (Fig.41). Por lo tanto, se puede inferir que eIF4E interacciona con Lsm-1 en células de $\mathrm{Dm}$.

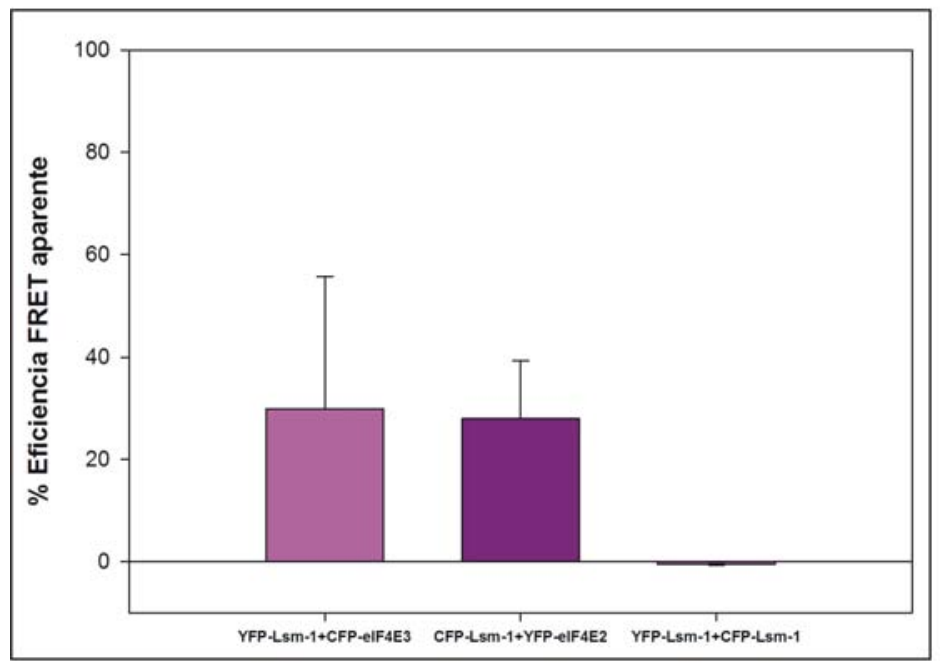

Figura 41. Eficiencia aparente de FRET de los pares YFP-Lsm-1/CFP-eIF4E-3 (15-40\%) y CFP-Lsm1/YFP-eIF4E-2 (20-40\%). Para el caso del par YFP-Lsm-1/ CFP-Lsm-1 la eficiencia de FRET es negativa $(-0,5$ a $-0,8 \%)$.

Cabe mencionar el hecho de que Lsm-1 se encuentra formando heptámeros con las variantes de Lsm, tanto en eucariotas inferiores como superiores (Ingelfinger et al., 2002). La eficiencia de FRET observada para el par YFP-Lsm-1/CFP-Lsm-1 (-0,5 a $0,8 \%$ ), estaría indicando en principio que no existe interacción. Este resultado, sumado a la evidencia de que en células HeLa, Lsm-3 interactúa con Lsm-2 y con Lsm-6 (Ingelfinger et al., 2002) nos permite suponer que Lsm-1 no forma homodímeros. La interacción de Lsm-1 con eIF4E, por sí sola o junto con otros factores, podría ser la encargada de transportar el complejo Lsm hacia los PB. Otra alternativa posible sería que el heptámero Lsm 1-7 se ensamble directamente en los PB, y no que venga preensamblado. Asimismo puede pensarse, que el factor Lsm-1, al igual que Me31B participa activamente del traslado de ARNm hacia $\mathrm{PB}$ en etapas tempranas del proceso.

En conclusión, la proteína eIF4E se encuentra en PB en células S2 de $D m$ en contacto molecular con Lsm-1 y Me31B. Es de esperar que el sitio de interacción no 
sea el de las 4E-BP debido a que ninguna de las dos proteínas posee el dominio necesario para dicha unión mencionado en secciones anteriores. En secciones posteriores se ampliará el análisis del sitio de interacción de eIF4E con Me31B.

No puede establecerse fehacientemente el hecho de que Me31B y Lsm-1 sean los encargados, junto a otros factores, de llevar a cabo la transición del ARNm desde

polisomas a PB sólo por el hecho de que interaccionan con eIF4E, sin embargo, la evidencia presentada (junto a otros estudios) apoya esta teoría, debido a que, los tres factores son indispensables para la formación de PB. Estudios de ARN de interferencia en humanos y en células S2 demostraron que la depleción de Me31B o Lsm-1 inhibe la formación de PB (Andrei et al., 2005; Eulalio et al., 2007b). Asimismo los factores que participan en la degradación de los mensajeros y que se encuentran en PB (Xrn1, Dcps,) no son necesarios para la formación de dichos gránulos, en contraste, su depleción incrementa el tamaño de los PB.

\subsubsection{Me31B y Lsm-1 no demuestran interacción por FRET.}

Una vez establecida la interacción de Me31B y de Lsm-1 con eIF4E, nos interesó evaluar si a su vez, Me31B y Lsm-1 están en contacto entre sí. Para ello se realizaron ensayos de FRET con los pares de proteínas de fusión CFP-Me31B/YFP-Lsm-1 y YFP-Me31B/CFP-Lsm-1. Los resultados obtenidos en este caso (Fig. 42), nos permiten suponer que las dos proteínas no están en contacto molecular en los PB. Sin embargo, como se ha indicado, no de puede descartar una interacción entre ellas. 


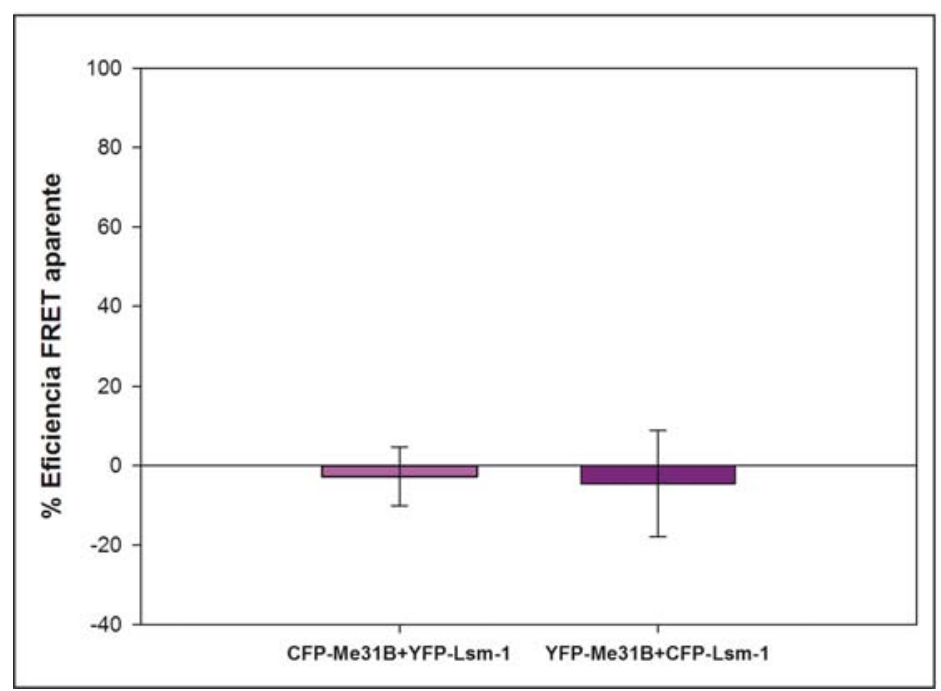

Figura 42. Eficiencia aparente de FRET para CFP-Me31B/YFP-Lsm-1 y YFP-Me31B/CFP-Lsm-1. En ambos casos las eficiencias son cercanas a 0 , y se considera que no existe interacción.

\subsubsection{Predicción de sitios de interacción mediante modelado por homología.}

En vista de los resultados obtenidos con eIF4E y sus mutantes, y con el fin de profundizar el estudio de la interacción entre Me31B y eIF4E realizamos el modelado por homología de la estructura de estas proteínas de Drosophila melanogaster y de eIF4E humana. Para esto se utilizó el programa Modeller (Eswar et al., 2006; MartiRenom et al., 2000); http://salilab.org/modeller/) realizando ajustes por minimización de energía y refinamiento. Se realizaron estudios de Docking para ver posibles sitios de interacción entre los modelos utilizando el programa AUTODOCK (http://autodock.scripps.edu/).

\subsubsection{Construcción de los modelos de Me31B y eIF4E.}

Para realizar los modelos de ambas proteínas se seleccionaron los moldes con la aplicación "blast-p" del "National Center for Biotechnology Information" (http://blast.ncbi.nlm.nih.gov/Blast.cgi?PAGE=Proteins) y se evaluaron en la base de datos de proteínas "Protein Data Bank" (http://www.pdb.org/pdb/home/home.do). 


\subsection{Modelo de Me31B}

Para realizar el modelado de Me31B se seleccionó, con la aplicación “blast-p”, el molde 1S2M de Sacharomyces cerevisiae, que corresponde a la estructura cristalina de Dhh1 (ortólogo de Me31B). Debido a la falta de información de este molde fue necesario la eliminación de algunos residuos, se eliminaron las porciones N-terminal (residuos 1-27) y C-terminal (residuos 402-459). De esta manera, el tamaño del modelo truncado corresponde a 375 aminoácidos (ver material suplementario). Utilizando el programa Modeller se realizó el alineamiento de secuencias (Fig. 43) y seguidamente se generó el archivo de coordenadas.

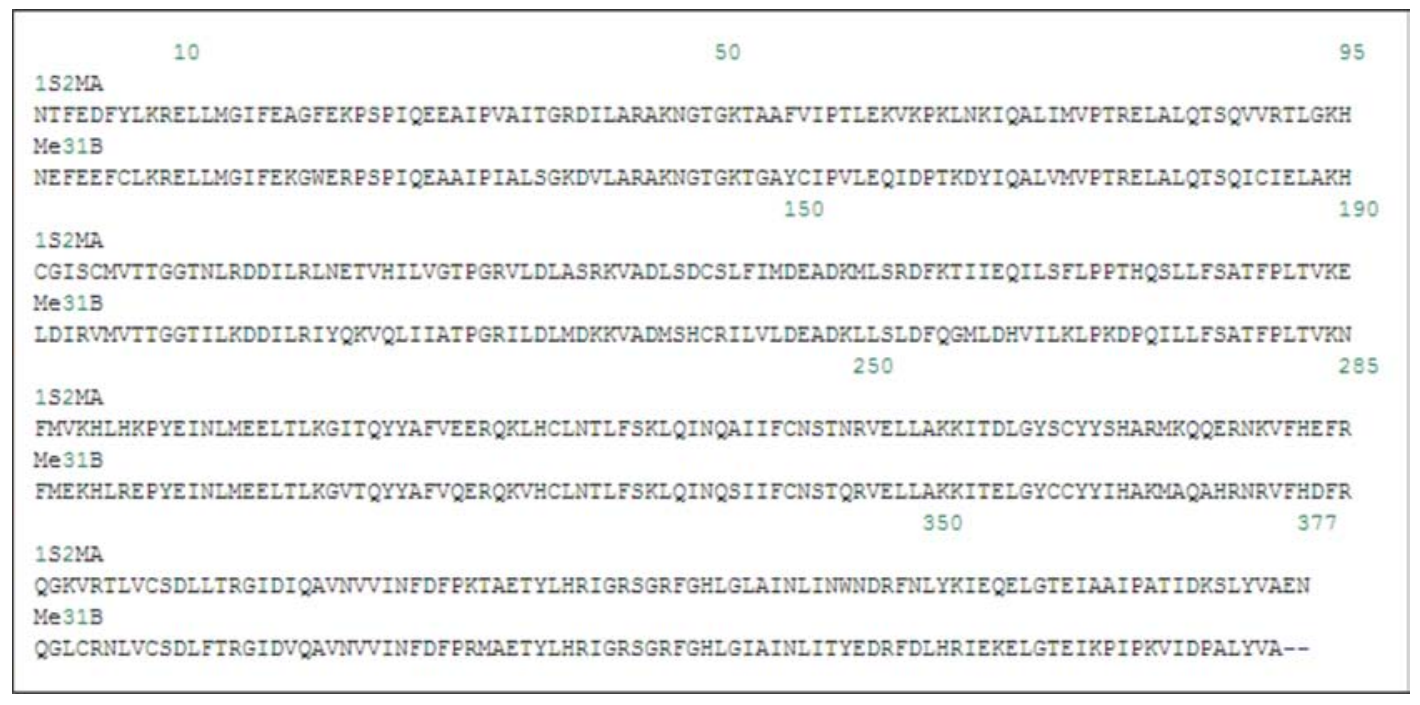

Figura 43. Alineamiento de secuencias entre el molde 1S2M de Sacharomyces cerevisiae y Me31B.

El paso siguiente para que el modelo sea lo más confiable posible fue la minimización de la energía, para esto se utilizó una combinación de los programas VMD (Visual Molecular Dynamics) y NAMD (Scalable Molecular Dynamics) (Humphrey et al., 1996). Finalmente se realizó el refinamiento de los loops, se ajustaron dos loops correspondientes a las regiones comprendidas entre los aminoácidos 202-213 y 327-336. Los modelos fueron evaluados mediante el Diagrama de Ramachandran (Ramachandran Plot) y el puntaje de DOPE (Discrete Optimized Protein Energy) en cada paso de ajuste energético (Fig. 44.) 


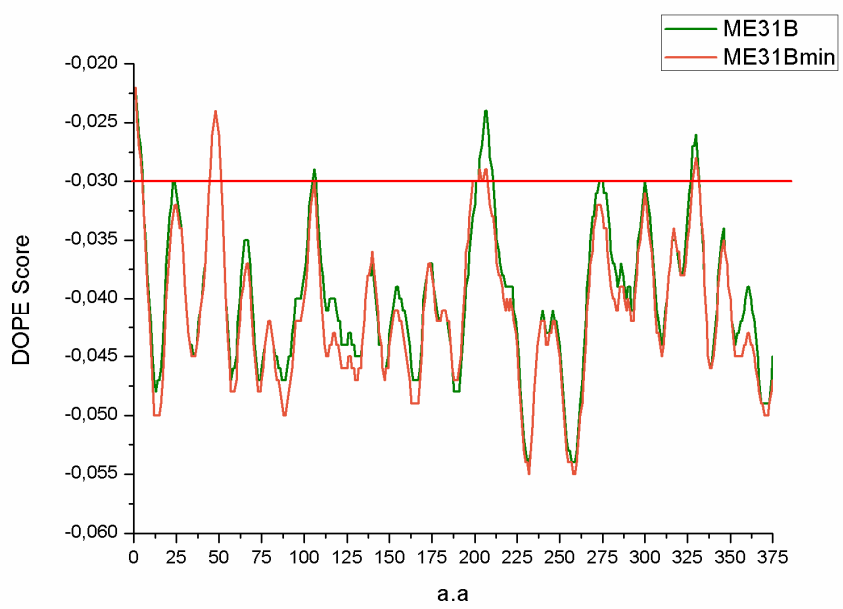

Figura 44. Diagrama de energía del modelo de Me31B. En verde se muestra el modelo inicial y en rojo el modelo ajustado energéticamente.

El modelo final obtenido para la proteína Me31B se muestra en la figura 45, puede apreciarse una conformación integrada por dos dominios globulares claramente visibles, los cuáles se unen a través de una región flexible.

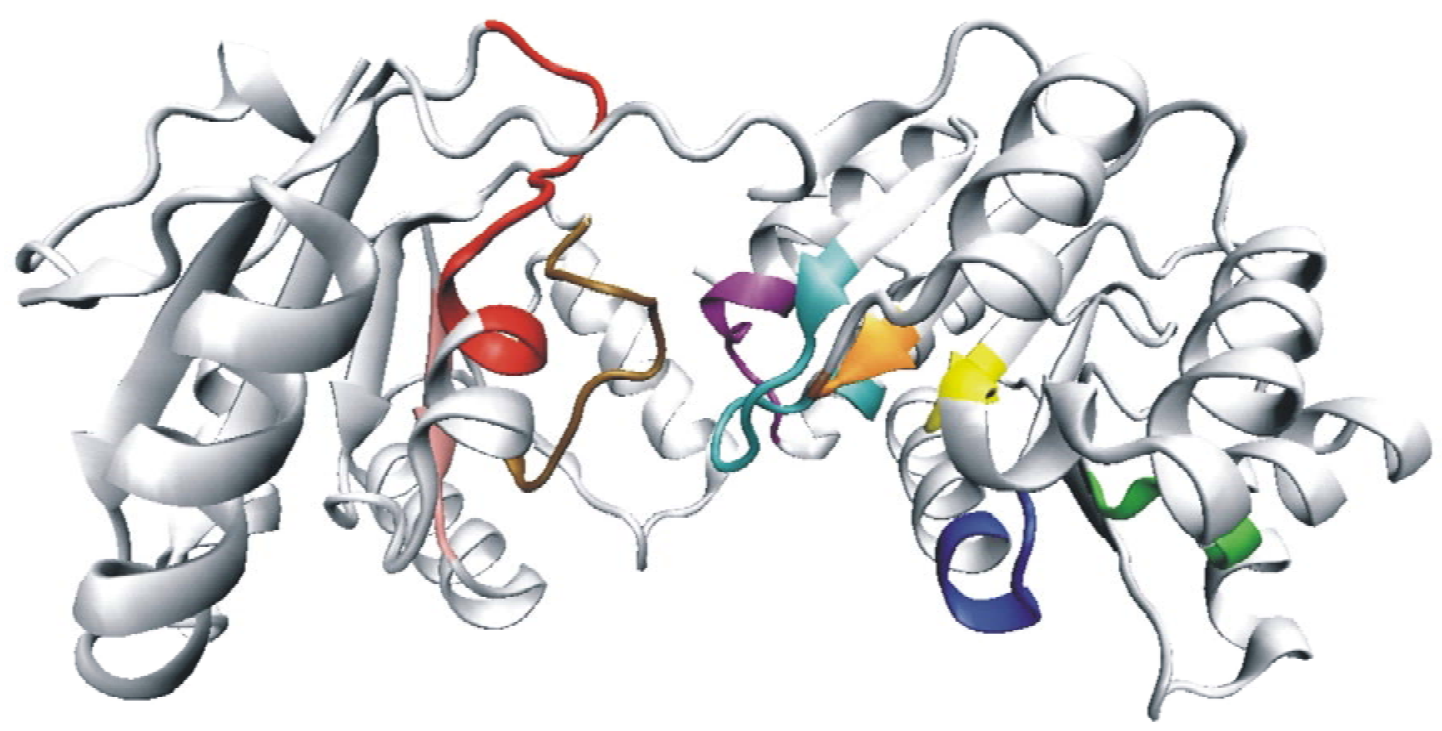

Figura 45. Modelo de la proteína Me31B. Dos dominios globulares separados por un lazo flexible. 


\subsection{Modelo de eIF4E}

Para realizar el modelado de eIF4E se escogieron los moldes 1WKW y 1EJ1, que corresponden a estructuras cristalinas de los complejos ternarios de eIF4E/m7GpppA/4EBP1 de humano y eIF4E/eIF4G/7-metil-GDP de ratón respectivamente. En este caso, fue necesaria la eliminación de los residuos de la secuencia N-terminal (residuos 1-70), por lo tanto, el tamaño del modelo truncado quedó de 189 aminoácidos (ver material suplementario). Se realizaron los alineamientos de secuencia (Fig. 46) con el programa modeller y se generó el archivo de coordenadas.

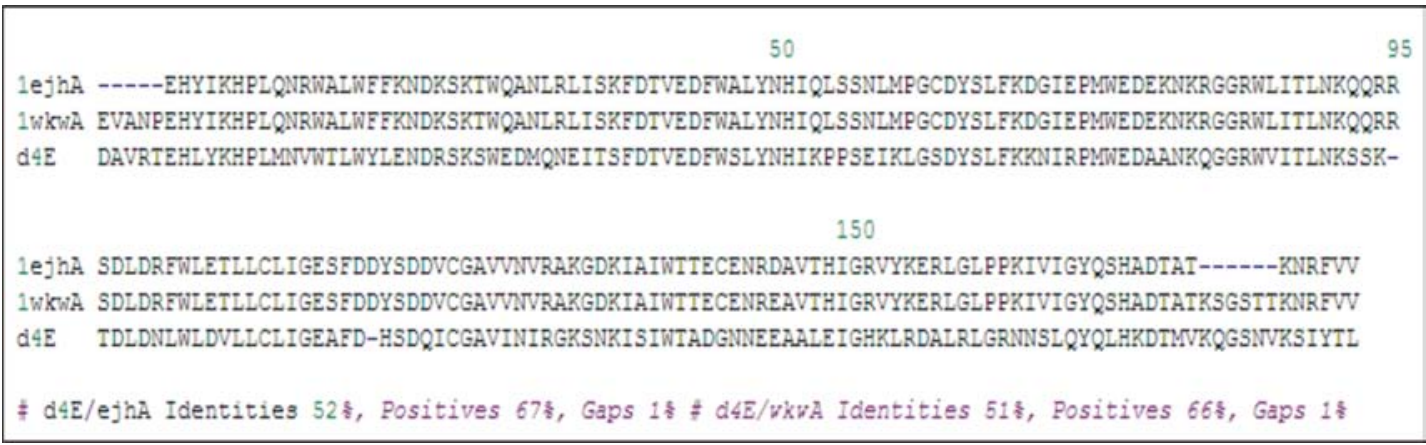

Figura 46. Alineamiento de secuencias de los moldes 1WKW y 1EJ1 con eIF4E.

Mediante una combinación de los programas VMD (Visual Molecular Dynamics) y NAMD (Scalable Molecular Dynamics) se produjo la minimización de la energía y finalmente se realizó el refinamiento de los loops. Los modelos fueron evaluados mediante el Diagrama de Ramachandran (Ramachandran Plot) y el puntaje de DOPE (Discrete Optimized Protein Energy) en cada paso de ajuste energético (Fig.47). La figura 48 muestra el modelo propuesto para eIF4E, en azul se muestran los residuos W100 y W146 involucrados en la unión al cap y en rojo el residuo W117 que participa en la unión a las proteínas 4E-BP. 


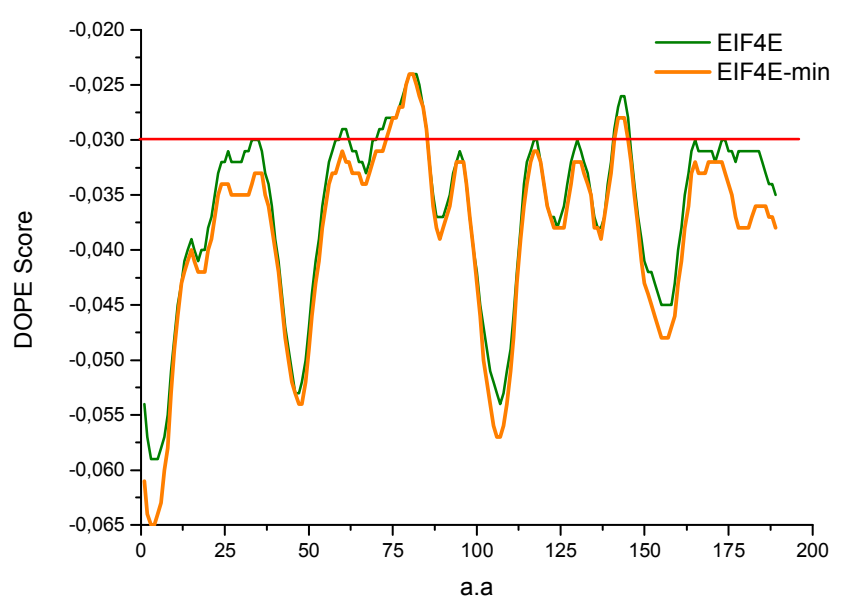

Figura 47. Diagrama de energía del modelo de eIF4E. En negro se muestra el modelo inicial y en naranja el modelo ajustado energéticamente.

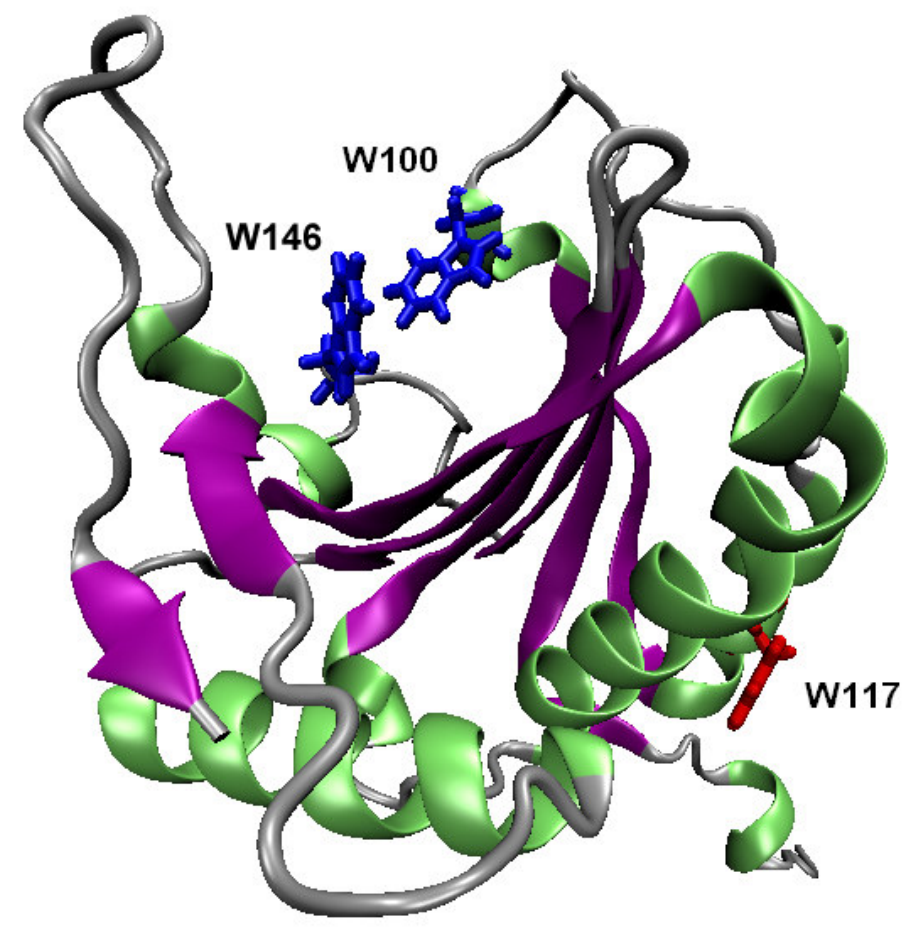

Figura 48. Modelo final obtenido para eIF4E, se marcaron los residuos $\mathrm{W}$ del sitio de unión a cap (azul) y de unión a 4E-BP (rojo). En verde las hélices alfa y en violeta las hojas beta. 


\subsubsection{Generación de archivos de Docking.}

Para realizar los estudios de docking, se estableció a eIF4E como receptor y a Me31B como ligando. Utilizando la interfaz gráfica de MGL-Tools se construyeron los archivos ".pdbqt” del receptor (modelo de eIF4E) y del ligando (modelo de Me31B), archivos de parámetros de grilla y de docking. Para ambos se fijó un índice de torsión nulo y con ausencia de residuos flexibles para simular un "docking rígido". Para la simulación se utilizó el paquete autogrid4 y autodock4 desde línea de comando. Se realizó un ranking por energía libre de interacción y RMSD para seleccionar el mejor de todos los modelos resultado de la simulación. El modelo elegido fue analizado con el programa $M G L-T o o l s$, y se visualizaron residuos cercanos y puentes hidrógeno (Fig. 49 y tabla 5). Para evaluar lo parámetros que se utilizaron en la simulación se realizaron controles que consistieron en re-ensamblar co-cristales obtenidos de la base de datos de RCSB (pdb: proteína data bank). Para esto se separa cada proteína del cocristal y se las trata a una como ligando y otra como receptor, y se lleva a cabo el docking. Para el control eIF4E vs. 4E-BP1 el $80 \%$ de los modelos se pegaron en el lugar esperado, con una energía libre promedio de $-15 \mathrm{Kcal} / \mathrm{mol}$. En el control del cocristal de eIF4E vs. eIF4G un 30\% de los modelos se ajustaron correctamente con una energía libre promedio de $-14 \mathrm{Kcal} / \mathrm{mol}$. 


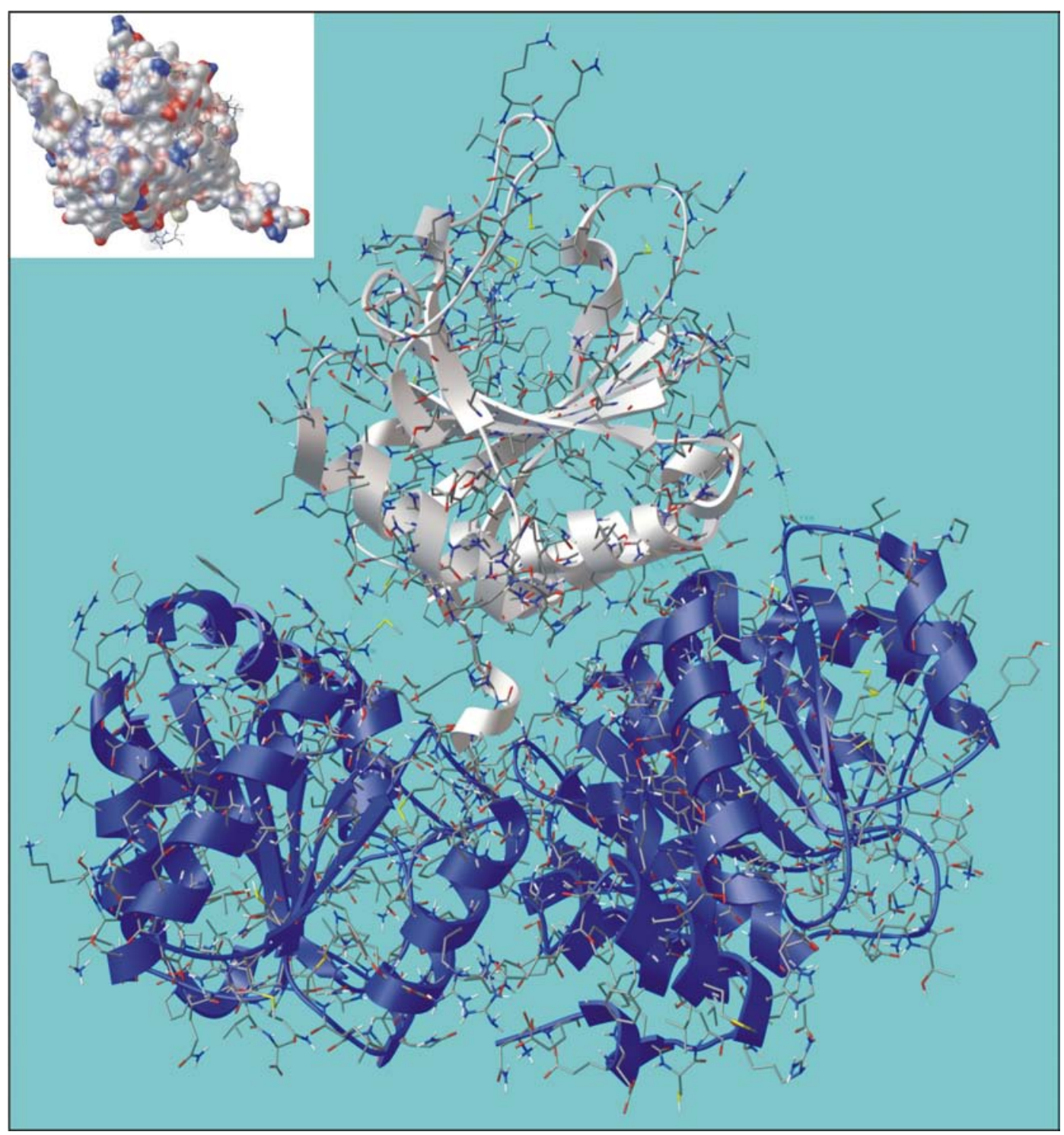

Figura 49. Modelo de interacción entre Me31B y eIF4E. Se asume por cuestiones prácticas que eIF4E actúa como receptor y Me31B como ligando. En la esquina superior izquierda se muestra a eIF4E con los parches de interacción marcados, junto a los residuos flotantes de Me31B. 


\begin{tabular}{|l|}
\hline LISTA DE RESIDUOS PREDICHOS. \\
\# Energía libre de int. $=-7$ kcal/mol \\
\# VdW scalling factor $=1$ A \\
\hline Residuos en el ligando-> residuos del receptor en estrecho contacto \\
\hline 1 :ASN51-> X:LEU158, \\
2 :MET14-> X:MET318, \\
3 :LYS93-> X:GLY106, \\
4 :ASP98-> X:THR78, X:GLU80, \\
5 :ASN101-> X:THR78, X:PRO77, X:LYS154, \\
6 :ASP116-> X:ARG317, \\
7 :PRO55-> X:ASP159, \\
8 :HIS52-> X:LEU158, \\
\hline Residuos en el receptor-> residuos del ligando en estrecho contacto \\
\hline 1 X:PRO77-> :ASN101, \\
2 X:GLY106-> :LYS93, \\
3 X:ASP159-> :PRO55, \\
4 X:ARG317-> :ASP116, \\
5 X:MET318-> :MET14, \\
6 X:GLU80-> :ASP98, \\
7 X:THR78-> :ASP98, :ASN101, \\
8 X:LEU158-> :ASN51, :HIS52, \\
9 X:LYS154-> :ASN101, \\
\hline Puentes de hidrógeno (residuo donor -> residuo acceptor) \\
\hline 1 M2d4E_tr_min1: :LYS93-> Me31B_truncada_min:X:GLY106, \\
2 Me31B_truncada_min:X:ARG317-> M2d4E_tr_min1: :ASP116 \\
\hline
\end{tabular}

Tabla 5. Residuos identificados como los sitios de contacto entre eIF4E y Me31B. 
Si bien en la construcción de modelos se trabaja con una alta identidad de secuencia, pueden mencionarse algunas observaciones. Para eIF4E se utiliza la información de la proteína co-cristalizada con el cap del ARNm y en presencia 4E-BP (eIF4G, Cup). La bibliografía sugiere que Cup forma un complejo con eIF4E y Me31B, estudios de coinmuno precipitación demostraron que las tres proteínas co-precipitan (Nakamura et al., 2004). Por otro lado, se demostró que Cup interacciona con eIF4E a través del sitio de unión de las 4E-BP, donde el W117 de eIF4E tiene un rol clave. En nuestro modelo este residuo se corresponde con el W47. Asimismo, se puede apreciar que este residuo queda expuesto en el modelo de interacción de eIF4E/Me31B propuesto, de manera tal que la tríada podría formarse.

La situación para Me31B es más compleja dado que esta proteína efectúa cambios conformacionales en presencia de sus ligandos habituales ATP y ARN. El molde utilizado para construir el modelo de Me31B es un cristal de la proteína en ausencia de los ligandos. Así, la información del molde utilizada para construir el modelo de Me31B no es estrictamente la configuración estructural funcional. Estudios previos proponen que eIF4E interacciona con Me31B de manera dependiente de ARN (Nakamura et al., 2004). Por lo tanto existirían dos alternativas posibles: eIF4E no interacciona directamente con Me31B sino que el ARN se une independientemente a ambas sin ellas estar vinculadas, o bien, eIF4E y Me31B interactúan físicamente pero requieren del ARNm para estabilizar y favorecer esta interacción. Las evidencias obtenidas en secciones anteriores, donde se pudo demostrar interacción directa por FRET in vivo entre eIF4E y Me31B, apoyan esta última hipótesis. 


\section{Discusión}

En este capítulo se evaluó la interacción de tres proteínas componentes de PB, las cuáles sospechamos son partícipes del remodelado de mRNP.

Se demostró que la proteína Lsm-1 y la helicasa Me31B interaccionan con el factor de inicio de la traducción eucariota 4E. Sin embargo, no se pudo demostrar la interacción entre Lsm-1 y Me31B con el método usado.

Estudios previos en levaduras demostraron que rck/p54 actúa facilitando la eliminación del cap de los mensajeros, asociada a Dcp1. Asimismo, se demostró que el complejo Lsm1-7 tiene un rol en la desadenilación que conduce al desplazamiento de los factores que participan en la traducción de ARNm (Tharun and Parker 2001), lo que sugiere que (junto con CCR4) también podrían desempeñar un papel en las primeras etapas del mecanismo de transición de un estado de traducción activa hacia la inactividad y/o degradación. Como se mencionó anteriormente, Me31B, y Lsm-1 son necesarios para la formación de $\mathrm{PB}$, la ausencia de alguno de ellos genera la pérdida de PB en $\mathrm{Dm}$. La depleción de la proteína CCR4 produce el mismo efecto. Sin embargo, la depleción de Dcp 1, Dcp 2, Xrn1 por $\mathrm{ARN}_{\mathrm{i}}$, no impide la formación de los PB. Por lo tanto, estos factores, que catalizan la eliminación del cap y la posterior degradación, no parecen jugar un papel en la localización de los mRNP en los PB, pero parecen actuar en una etapa posterior (es decir, después de que los mRNP se acumulan en los PB).

El modelado de las proteínas eIF4E y Me31B permitió generar un modelo que apoya la idea de interacción entre estos dos componentes. Se encontraron varios puntos de contacto en el modelo propuesto, esperamos poder llevar a cabo futuros experimentos de mutagénesis en algunos de estos sitios, y evaluar si se ve alterada la interacción, con el fin de reconocer los residuos clave en esta unión. 
3. Discusión general 
Durante esta tesis se estudió la composición de PB de células S2 de Drosophila melanogaster, particularmente el estudio se centró en el factor de inicio de la traducción eucariota. Se dilucidaron interacciones entre las proteínas componentes de PB, para poder interpretar los complejos ribonucleoproteicos. El estudio de la formación y composición de distintos gránulos citoplasmáticos ha avanzado mucho recientemente. Sin embargo la dinámica de la remodelación y las interacciones in vivo requieren un mayor estudio. Por lo tanto es fundamental ahondar en la descripción y la comprensión de estos diversos aspectos, ya que forman parte de los mecanismos de regulación post-transcripcional que modulan la expresión de los genes. En esta sección enmarcaremos nuestros resultados dentro del campo de conocimiento de gránulos de ARN, las interacciones entre sus componentes, y la regulación de la traducción.

\section{Gránulos citoplasmáticos}

Los gránulos citoplasmáticos de ARNm, pueden ser encontrados en una gran variedad de configuraciones de acuerdo a su contenido de proteínas. Estas estructuras tienen roles importantes en la regulación post-transcripcional de la expresión genética (Anderson and Kedersha, 2006). Son estructuras en las que se acumulan los mensajeros traduccionalmente inactivos. En algunos casos los mensajeros son degradados y en otros silenciados. El origen de los transcriptos en los foci es el ARNm activo en polisomas. Esto se demuestra al "atrapar" a los transcriptos en polisomas por el tratamiento con cicloheximida. En estos casos se bloquea la formación de gránulos. Esta es una respuesta común para SG y PB observada tanto en células de mamíferos como en levaduras (Cougot et al., 2004; Sheth and Parker, 2003; Wilczynska et al., 2005).

Existe una colección de diferentes complejos ribonucleoproteicos, la mayoría de los cuáles no han sido caracterizados, aunque se han estudiado en más detalle los PB y SG. En el desarrollo de esta tesis nos centramos en estos dos tipos de estructuras, aunque ponemos en evidencia la variabilidad en la composición.

Los SG aparecen en las células frente a condiciones de estrés. La iniciación de la traducción es el paso clave sobre el cuál actúan los factores de regulación. Por lo tanto, 
es el más sensible a cambios en el entorno celular, incluyendo el estrés. Un paso clave en la inhibición de la iniciación de la traducción es la fosforilación de eIF2 $\alpha$, que resulta en un aumento de la afinidad de eIF2-GDP por eIF2B, secuestrándose este factor para evitar nuevas rondas de iniciación de la traducción (Yamasaki and Anderson, 2008). Durante este proceso, se inhibe la traducción y se acumulan los polisomas, lo que conduce a un aumento de mRNP inactivos en SG. En esta tesis nos centramos en el estudio de tres componentes de los gránulos citoplasmáticos: Me31B, Lsm-1 y eIF4E. De estos factores sólo encontramos a eIF4E formando parte de los gránulos generados por estrés con arsenito de sodio (Fig. 12 y Fig. 24). Sin embargo, hay que tener presente que la composición de los gránulos puede variar dependiendo del tipo de estrés. En levaduras, fue demostrado que el estrés inducido con azida de sodio produce la formación de SG con una composición diferente a los generados por deprivación de glucosa (Buchan et al., 2011). La interpretación más simple de estas observaciones es que complejos mRNP individuales se estancan en diferentes etapas de la iniciación de la traducción como consecuencia de distintas condiciones de estrés. Esto conduce a la acumulación de distintos complejos de iniciación de traducción en los gránulos de estrés, lo que resulta en una composición aparentemente diferente de gránulos. Por otro lado, frente a diferentes condiciones de estrés las células deberían expresar diferente proteoma, por lo tanto, no serán siempre los mismo los mensajeros silenciados, y consecuentemente se modificarán los factores que acompañan a los ARNm hacia los SG (Thomas et al., 2011).

Los PB forman parte de las estructuras constitutivas de las células, contienen una amplia gama de componentes que participan en procesos post-transcripcionales. Esto indica que poseen un papel central en la regulación de la expresión génica. Contienen enzimas que son necesarias para cada fase de la vía de degradación del ARNm, entre ellas se encuentran la desadenilasa CCR4, un complejo enzimático decapping incluyendo Dcp1/2, y rck/p54, una exonucleasa Xrn1, etc. (Anderson and Kedersha, 2006). En células de mamíferos, se encuentran además componentes que participan en el silenciamiento de ARN (proteínas Argonautas y microRNA). No posen componentes de la maquinaria de iniciación de la traducción a excepción de eIF4E (Andrei et al., 2005). Se propone que en estas estructuras, además de ocurrir degradación de ARNm, se produce su almacenamiento. Luego de un tiempo estos 
ARNm silenciados son enviados de regreso a polisomas donde vuelven a ser traduccionalmente activos (Parker and Sheth, 2007). Aquí demostramos que la enzima helicasa Me31B, la proteína Lsm-1 y el factor de inicio de la traducción eucariota se encuentran en PB en células S2 de Dm (Fig. 7, Fig. 9 y Fig. 12).

En esta tesis demostramos que eIF4E co-localiza con diferentes componentes, tanto de PB (Me31B, Lsm-1, GW182) como de SG (TIA-1), y esta co-localización no ocurre de la misma manera en dichos gránulos. En algunos casos, los gránulos contienen uno, otro o ambos componentes. Asimismo en las estructuras donde se encuentran ambos componentes, la cantidad de cada uno varía cuantitativamente de un granulo a otro. Esto implica la existencia de una diversa composición de los foci en las células. Esta variabilidad en la composición de los gránulos puede ser el resultado de observar in vivo estadios intermediarios en la formación de un tipo de gránulo en particular, o de la dinámica y el intercambio de componentes entre ellos.

A pesar de que los PB y SG son estructuras diferenciadas por su contenido proteico y pueden existir separadamente, hay evidencia de que ambos gránulos intercambian componentes entre ellos (Buchan et al., 2008; Thomas et al., 2011). Se propone que, frente a situaciones de estrés, los SG se formarían poniendo a salvo a los mensajeros en dicho estado junto con la maquinaria traduccional. Posteriormente, estos mensajeros son enviados hacia $\mathrm{PB}$, donde son degradados o permanecen inactivos hasta que alguna señal desencadene su reingreso en los polisomas para que sean traducidos activamente (Anderson and Kedersha, 2008; Buchan and Parker, 2009).

Por otro lado se han caracterizado diferentes tipos de gránulos de ARN, algunos de los cuáles comparten componentes diferenciales con PB y otros con SG. Por ejemplo en $C$. elegans se han caracterizados los gránulos blastomere germ granules, los arrested ovulation oocyte foci, y los P granules (Amiri et al., 2001; Anderson and Kedersha, 2006), en ratas se caracterizaron PB dendríticos (Buchan and Parker, 2009) entre otros. Sin embargo estos mRNP contienen algunos componentes de PB y otros de SG. En particular los $P$ granules contienen y requieren eIF4E (Amiri et al., 2001). En Drosophila se conocen, además de los PB y de los SG caracterizados aquí, gránulos de transporte neuronales (Barbee et al., 2006), los cuáles también poseen componentes tanto de PB como de SG y así también componentes particulares como la proteína Smaug (Baez and Boccaccio, 2005). Esto amplia mucho más el polimorfismo 
de los complejos mRNP, los cuáles varían dependiendo de los organismos, de la etapa de desarrollo, de la localización y de factores externos como el estrés o el estado celular.

Constantemente se van incorporando nuevos conocimientos sobre estas complejas estructuras y se van incorporando nuevos factores. Pero la comprensión de la dinámica de los mRNP está lejos de ser clara, quedando aun por descubrir nuevos e impredecibles caminos.

\section{Las dos caras del factor de inicio de la traducción eucariota.}

En esta tesis se estudiaron 4 de las 8 isoformas de eIF4E de Drosophila melanogaster. eIF4E-1 (CG4035) posee 48\%, 37\% y 35\% de identidad con los homólogos en levaduras, mamíferos, y trigo respectivamente. Varios residuos (incluidos ocho triptofanos característicos de esta proteína), cruciales para la función en los mamíferos y las levaduras están conservados en esta isoforma (Hernandez et al., 2005; Hernandez and Sierra, 1995; Hernandez and Vazquez-Pianzola, 2005). eIF4E-1 es la más abundante en $D m$ y está presente a lo largo de todas las etapas del desarrollo. La misma fue encontrada en gránulos citoplasmáticos constitutivos (PB) y en gránulos inducidos por estrés con arsenito de sodio. Los mismos resultados fueron previamente demostrados para las ortólogas en humanos y levaduras (Brengues and Parker, 2007; Kedersha et al., 2005)

La isoforma eIF4E-2 (CG4035) está codificada por el mismo gen que la 1, por lo que es muy similar, sólo difieren en 11 aminoácidos en el extremo N-terminal que están ausentes en esta isoforma y presentes en eIF4E-1. Sin embargo, se sabe que la región N-terminal no es imprescindible para las funciones conocidas de estos factores (Hernandez et al., 2005; Hernandez and Sierra, 1995; Lachance et al., 2002). Aquí se demostró que esta isoforma también es encontrada en gránulos citoplasmáticos tanto en PB como en SG (Fig. 12).

eIF4E-3 (CG8023) esta presente en los embriones en baja cantidad y aumenta su expresión en el tercer estadío larvario. La serina 251, crítica para la función de eIF4E-1 en Drosophila (Lachance et al., 2002), esta ausente en esta isoforma y sin 
embargo, al igual que la isoforma 1, se encuentra en PB y SG en células S2 de Dm (Fig. 12).

Finalmente la isoforma d4E-HP (antiguamente eIF4E-8, CG33100) tiene alta similitud con la proteína 4E-HP humana (Cho et al., 2005; Hernandez et al., 2005). Estas poseen una sustitución en el residuo K159 que forma el puente salino con la S251 para interaccionar con el cap de los ARNm. También fue encontrada tanto en PB como en SG en células S2 (Fig. 12).

Por lo tanto las 4 isoformas del factor de inicio de la traducción eucariota de Drosophila melanogaster forman parte tanto de PB como de SG y son clave para la regulación de la traducción de mensajeros. Durante la embriogénesis de Dm la regulación de la traducción desempeña un papel central en la localización de morfógenos maternos, incluyendo a Bicoid y Nanos. Los ARNm que codifican estos morfógenos están localizados en los polos opuestos del embrión, esto produce el establecimiento de gradientes de concentración de las proteínas codificadas en todo el embrión, posterior a anterior o anterior a posterior. Las proteínas Bicoid y Nanos funcionan en el citoplasma para suprimir la traducción de los ARNm que codifican otros morfógenos (caudal y hunchback), los cuáles están distribuidos uniformemente en el embrión. Bicoid reprime la traducción del ARNm de caudal en la parte anterior del embrión, donde está presente, mediante la unión simultáneamente a la región 3'UTR del mensajero de caudal y a d4E-HP en el extremo 5' del ARNm (Cho et al., 2005). De manera similar d4E-HP se une a un complejo de proteínas que contiene a Nanos en la región 3'UTR del ARNm de hunchback para inhibir su traducción en la parte posterior (Cho et al., 2006). Asimismo, eIF4E-1 también tiene asociadas funciones en la regulación de proteínas claves durante el desarrollo. Junto a la proteína Cup regula la expresión del mensajero de oskar en la oogénesis (Nakamura et al., 2004). Durante la oogénesis y los estadios embrionarios tempranos el control de la traducción es central. Es destacable que los factores que afectan estos procesos se encuentran acumulados en gránulos, como por ejemplo los que forman el plasma polar (posterior), entre ellos Cup, Vasa, Me31B, etc. Esto es similar a lo descripto para otros gránulos en Xenopus, C. elegans y otros organismos (Anderson and Kedersha, 2006; Buchan and Parker, 2009; Eulalio et al., 2007a). 
Por otro lado, encontramos que los mutantes eIF4E-1 ${ }^{\mathrm{W} 100 \mathrm{~A}}$, eIF4E-1 ${ }^{\mathrm{W} 146 \mathrm{~A}}$ y el doble mutante eIF4E-1 ${ }^{\mathrm{W} 100 \mathrm{~A} / \mathrm{W} 146 \mathrm{~A}}$ localizan tanto en PB como en SG (Fig. 22 y Fig. 24) Asimismo d4E-HP posee el residuo Y68 (correspondiente a W100 de eIF4E-1, Fig. 50) y también se la encontró en gránulos como mencionamos anteriormente. Por lo tanto podemos concluir que los triptofanos claves en la unión de estos factores al cap de los mensajeros, no son esenciales para su localización en PB y en SG. Entonces, ¿serán los residuos que participan de la unión a eIF4G y a las 4E-BP los responsables de su localización en gránulos?

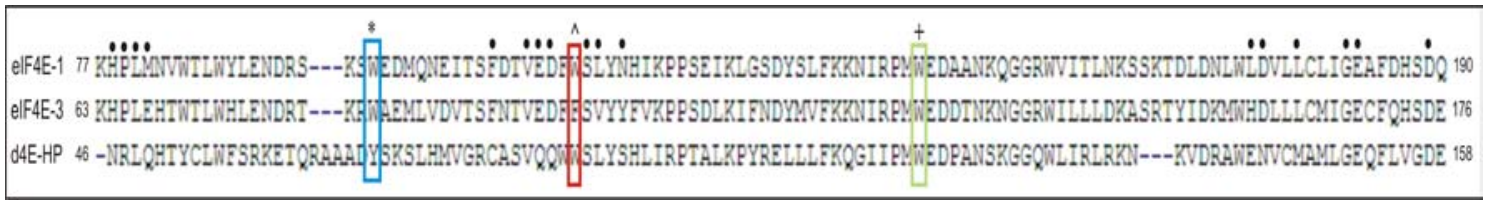

Figura 50. Alineamiento de secuencia de las proteínas eIF4E-1, eIF4E-3 y d4E-HP. La secuencia de las proteínas alineada permite observar las variaciones en los residuos de unión a eIF4G y 4E-BP (marcados con $\bullet$, a excepción del residuo en el recuadro rojo, marcado con ${ }^{\wedge}$,W117 de eIF4E-1). Los recuadros azul (*, W100 de eIF4E-1) y verde (+, W146 de eIF4E-1) marcan los residuos triptofanos más importantes que participan en la unión al cap.

Se sabe desde hace largo tiempo que la proteína eIF4G interacciona con eIF4E para iniciar la traducción eucariota (Jackson et al., 2010), y se postula que uno de los principales mecanismos de inhibición de la traducción sería por competencia por el sitio de unión de eIF4G por otros factores, tales como eIF4E-T (Jackson et al., 2010). Por lo tanto es de esperar que la localización de estos factores en PB y SG dependa de los sitios de unión a eIF4G. Sin embargo, d4E-HP posee varias sustituciones en dichos residuos, y fue demostrado que no interacciona con eIF4G in vitro (Hernandez et al., 2005). Aquí demostramos que el mutante eIF4E-1 ${ }^{\mathrm{W} 117 \mathrm{~A}}$ produce la deslocalización de gránulos citoplasmáticos. Sin embargo, eIF4E-3 que posee una fenilalanina en la posición 103 (correspondiente a W117 en eIF4E-1, Fig. 50), se ubica en PB, mientras que, el mutante eIF4E-3 $3^{\mathrm{F} 103 \mathrm{~A}}$ esta deslocalizado, al igual que eIF4E-1 ${ }^{\mathrm{W} 117 \mathrm{~A}}$. Por lo tanto, podemos decir que la fenilalanina (similar al triptófano en su estructura aromática) evita la perdida de localización en gránulos. A pesar de esto, es el residuo W117 el que determina la localización de los factores en gránulos citoplasmáticos. De 
la misma manera, como se mencionó anteriormente, d4E-HP se encuentra en gránulos y sin embargo, posee sustituciones en muchos de los residuos que participan en la unión con las 4E-BP (Fig. 50) a excepción del triptófano 85 (que se corresponde con el W117 de eIF4E-1) que permanece intacto. Por lo tanto podemos establecer que, de los residuos que participan en la unión a las 4E-BP, el encargado de la localización en gránulos es particularmente el residuo W117 (en eIF4E-1 o su equivalente en las demás isoformas) y no otros de ellos, proponiendo que pertenece a un dominio diferente.

Existen algunos aspectos sobre d4E-HP que aún no quedan claros en base a los conocimientos adquiridos hasta el momento. Esta demostrado que d4E-HP no interacciona con eIF4G o 4E-BP (Hernandez et al., 2005), por lo tanto no cabría esperar una interaccionar con eIF4E-T, ya que eIF4E-T comparten el sitio de unión a eIF4E con eIF4G y 4E-BP (Dostie et al., 2000; Suzuki et al., 2009). Teóricamente d4E-HP no debería entonces, acumularse en complejos traduccionalmente inactivos, sin embargo se demostró que la interacción con Bicoid ocurre y que en Bicoid existe un sitio diferente al clásico YxxxxLф presente en las 4E-BP (Cho et al., 2005). Por lo tanto esto no debería afectar el silenciamiento de este mensajero. Estos datos indican que el dominio de interacción con eIF4E es variable en distintos reguladores. Y también muestra que en el caso de d4E-HP, la no conservación del dominio de unión a eIF4G y 4E-BP no impide la interacción con Bicoid. Por lo tanto, es razonable postular que son dominios diferentes. En nuestro caso, observamos que la presencia de un aminoácido aromático ( $\mathrm{F}$ o W) en la posición equivalente a W117 de eIF4E-1 es necesaria para la acumulación en foci y que este residuo deberá ser parte de un dominio diferente al de interacción con eIF4G y 4E-BP, además de eIF4E-T. Esto lleva a considerar que si se detectó la interacción simultánea de eIF4E con rck/p54 y eIF4E-T en PB de células HeLa (Andrei et al., 2005) estas interacciones se lleven a cabo en dominios diferentes y no excluyentes. El caso de d4E-HP demuestra la gran complejidad de los complejos de silenciamiento, no todos los factores cumplen las reglas generales, depende del organismo y del estadio del mismo. Incluso dentro del mismo organismo existen variaciones. Aún quedan muchos estudios por realizar para dilucidar el silenciamiento de los mensajeros particulares, sólo tenemos una idea de los mecanismos generales. 


\section{Lsm-1 y Me31B como proteínas nucleadoras de PB}

Me31B (CG4916) es una proteína con actividad helicasa ortóloga a rck/p54 de humanos (de Valoir et al., 1991). El análisis del genoma de Drosophila muestra que al menos otra proteína ortóloga de rck/p54 esta codificada y que muestra alta similitud con Dhh1 (Gem3, CG6539). Sin embargo, la función de este gen y la capacidad de helicasa de la misma no han sido comprobadas aun y su estudio escapa a los objetivos de esta tesis. Se ha sugerido que Me31B media el silenciamiento de ARN específicos

durante su transporte en la ovogénesis, sugiriendo que el transporte de ARN y el control de la traducción están vinculados a través de la formación mRNP (Nakamura et al., 2001).

La proteína Lsm-1 se conoció en $S$. cerevisiae, forma parte de una familia de proteínas que poseen un dominio común de 7 aminoácidos conservados. Algunas de ellas tienen funciones en el splicing del ARN (Cooper et al., 1995; Hermann et al., 1995; Mayes et al., 1999; Pannone et al., 1998; Salgado-Garrido et al., 1999; Seraphin, 1995; Stevens and Abelson, 1999). Por otro lado Lsm-1 puede promover el decapping del ARNm por medio de su interacción con el ARNm y con la maquinaria de decapping en levaduras. Las proteínas Lsm forman oligomeros específicos que afectan diferentes aspectos del metabolismo del ARNm (Tharun et al., 2000).

Me31B y Lsm-1 son requeridos para la formación de PB (Andrei et al., 2005; Eulalio et al., 2007b). Aquí demostramos que estos dos componentes cruciales de los PB interactúan con eIF4E. Sin embargo no pudo ser demostrada la interacción entre Lsm-1 y Me31B en PB de células S2 de Drosophila melanogaster.

Estudios previos en células HeLa demostraron que la proteína eIF4E-T también interacciona con eIF4E (Andrei et al., 2005), a través del sitio de unión a las 4E-BP. Por otro lado se demostró que eIF4E-T es un represor de la traducción (Ferraiuolo et al., 2005). Se plantea por lo tanto, que es una de las encargadas de iniciar el remodelamiento de mRNP. En $D m$ se ha asignado un valor equivalente a la proteína Cup. Estudios sobre Cup demostraron que posee varias funciones, la mayoría de ellas relacionadas a la regulación de la traducción. Actúa durante el desarrollo inhibiendo la expresión de algunos mensajeros (nanos y oskar), actúa en el transporte núcleocitoplasmático, interactúa con eIF4E para controlar la iniciación de la traducción 
durante el desarrollo del ovario y el crecimiento, y existe evidencia de que participa en la regulación de la fosforilación de eIF4E en la serina 251 (clave para la unión al cap) (Piccioni et al., 2005). Por lo tanto, Cup estaría cumpliendo varias funciones imprescindibles, una de las cuales es participar en el remodelamiento de mRNP.

Estudios previos en levaduras demostraron que rck/p54 actúa facilitando la eliminación del cap de los mensajeros, asociada a Dcp1. Asimismo, se demostró que el complejo Lsm1-7 tiene un rol en la desadenilación que conduce al desplazamiento de los factores que participan en la traducción del ARNm (Tharun and Parker 2001), lo que sugiere que también podrían desempeñar un papel en las primeras etapas del mecanismo de transición de un estado de traducción activa hacia la inactividad y/o degradación. Como se mencionó anteriormente, eIF4E, Me31B, y Lsm-1 son necesarios para la formación de PB. Sin embargo, la eliminación de Dcp1, Dcp2 y Xrn-1 no impide la formación de los PB. Por lo tanto, estos factores, que catalizan la eliminación del cap y la posterior degradación, no parecen jugar un papel en el transporte de los mRNP a los PB y su nucleación. Actúan en una etapa posterior, es decir, después de que los mRNP se acumulan en los PB.

Finalmente podemos concluir que Me31B, Cup y Lsm-1, participan activamente en el remodelamiento de los polisomas a través de su interacción con eIF4E, generando la eliminación de la maquinaria de traducción del complejo, la reorganización de los componentes y el direccionamiento hacia PB. Completada esta primera etapa se incorporan los factores encargados del procesamiento de los mensajeros (enzimas Dcps, Xrn1, entre otros). Asimismo, los modelados de las proteínas eIF4E y Me31B, y el modelo de interacción propuesto entre ellos permite la unión de Cup en su sitio de interacción con eIF4E, por lo tanto, estaría apoyando esta teoría. 


\section{Modelo de remodelamiento: de polisomas a gránulos de silenciamiento}

Basándonos en los resultados obtenidos que demuestran que los residuos indispensables para la unión al cap no son requeridos para la localización de eIF4E en $\mathrm{PB}$, podemos postular que eIF4E no necesariamente debe mantenerse unido a los mensajeros a través del cap (como se ha propuesto previamente) sino que podría quedar relacionado con el ARNm por medio de interacciones con otros componentes de la maquinaria de traducción o remodelamiento. Esto no implica que no utilice el cap, sino que esta unión es innecesaria. Durante la traducción eIF4E se encuentra en el complejo eIF4F (eIF4E-eIF4G) y se une al cap de los ARNm para dar lugar a la primera etapa de iniciación de la traducción (Jackson et al., 2010; Sonenberg and Hinnebusch, 2009). En esta etapa, eIF4E acerca la proteína multi adaptadora eIF4G para reclutar otros factores de iniciación. Sin embargo, esto no sucedería con los mensajeros cuya traducción es independiente del cap. Ensayos in vitro en células HeLa demostraron que el mutante eIF4E $\mathrm{E}^{\mathrm{W} 102 \mathrm{~L}}$ (mutante humano en el sitio análogo a W146 de eIF4E-1 de Drosophila melanogaster) es incapaz de unirse al cap de los ARNm pero puede, sin embargo, producir el inicio de la traducción (De Gregorio et al., 2001) si es reclutado artificialmente al ARNm por otros mecanismos (en este caso se usó el agregado de un dominio de unión a ARN de la proteína $\mathrm{N}$ del fago lambda a eIF4E y de una secuencia específica de unión, el box B, al ARNm). Es decir que no es la unión al cap en sí misma, sino la unión de eIF4E al ARNm lo que determina su capacidad de iniciación. En este contexto, podemos hipotetizar que, contrariamente a lo que postula el paradigma de la iniciación, que es la liberación de eIF4E y demás factores de traducción en cada ronda de iniciación, eIF4E podría permanecer junto al ARNm durante todo el proceso de traducción en un "rol pasivo" hasta que es nuevamente activo, luego de la iniciación de la traducción, para participar del remodelamiento de mRNP de una manera independiente del cap. Esto podría explicar porque es el único factor de la iniciación de la traducción que se encuentra tanto en complejos mRNP activos como inactivos en PB. Una idea más arriesgada sería considerar que el papel de eIF4E no es pasivo sino que participa activamente en la traducción sin liberarse. Esto permitiría explicar la aparente contradicción de la circularización del ARNm mediada por eIF4E-eIF4G-PABP con la liberación de los factores de traducción. Pero 
no contamos con evidencia experimental que lo pruebe. También queda la incógnita de como se encuentran estructuralmente los ARNm en las estructuras de silenciamiento.

En base a todos los datos recopilados en esta tesis y a datos publicados por otros laboratorios podemos plantear un modelo de remodelamiento secuencial de mRNP. Las proteínas eIF4E, Cup, Me31B, y Lsm-1, tienen un papel crucial durante las etapas tempranas del remodelamiento. Estos cambios implican reasociaciones con nuevos componentes o cambios de interacciones entre los componentes existentes. Esto sucede en los PB durante la integración de un ARNm como complejo inactivo (Fig. 51). Proponemos un modelo en el cual, en una primera etapa Cup (u ortólogo de eIF4E-T) compite con eIF4G por el sitio de unión a eIF4E, reprimiendo la traducción, y simultáneamente eliminando la maquinaria traduccional del ARNm. En una segunda etapa se reclutarían factores necesarios para la nucleación o agregado de los PB tales como Lsm-1 y Me31B (ortólogo de rck/p54). Finalmente se agregan los componentes que participan en el metabolismo de los ARNm (enzimas Dcp, Xrn1, entre otros. Este modelo no propone ni descarta un direccionamiento vectorial del ARNm hacia gránulos sino el ensamblado directo sea donde sea que los factores se encuentren. Esto significa que un grupo de ARNm puede actuar como centro de nucleación de nuevos foci o bien ser agregado en foci preexistentes. Estos posibles intermediarios de nucleación podrían explicar la diversidad de composición de los gránulos.

Por otro lado, los ARNm pueden ir desde los polisomas a los SG frente a algún estímulo que genere estrés celular, allí los mensajeros serán protegidos junto con a algunos componentes de la maquinaria de traducción. Posteriormente, cuando cesa el estímulo de estrés, los mensajeros pueden retornar a polisomas. Los SG podrían intercambiar componentes con los $\mathrm{PB}$, algunos de los mensajeros pueden pasar a los PB para ser degradados o almacenados. $\mathrm{Y}$ a su vez podrían intercambiarse componentes proteicos.

La relación dinámica entre polisomas, PB y SG, demuestra la importancia del proceso de regulación del destino de los ARNm citoplasmáticos. Estos procesos participan en el establecimiento del proteoma celular. 


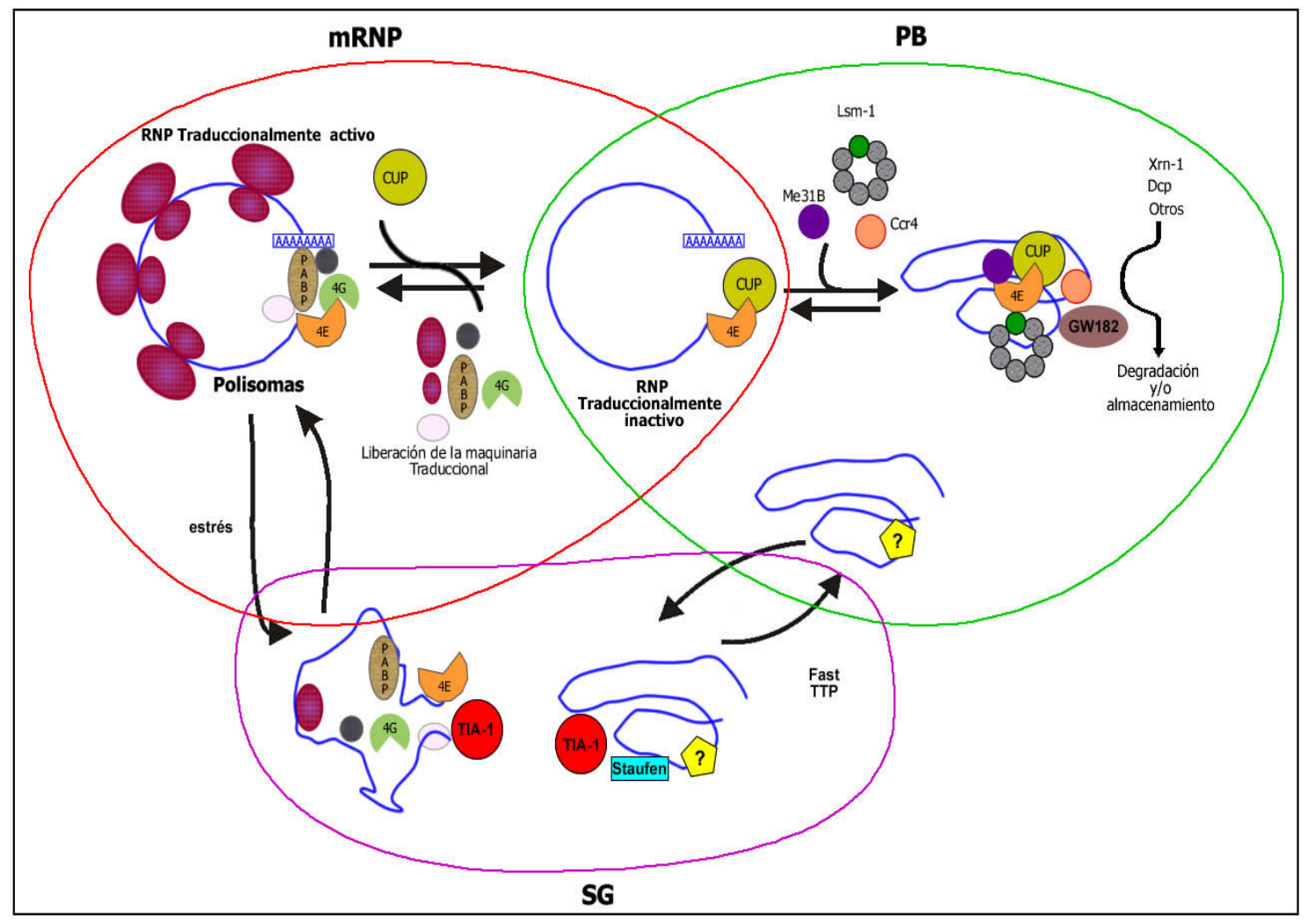

Figura 51. Modelo de remodelamiento secuencial donde los complejos mRNP pasan de un estado de traducción activa hacia un estado reprimido. Se propone que algún factor (en este caso Cup) inicia el proceso, generando la inhibición de la traducción, y la eliminación de la maquinaria de traducción. A continuación se van incorporando otros factores, entre ellos, las proteínas Me31B y Lsm-1 interaccionan directamente con eIF4E, generando la acumulación en PB. Finalmente se incorporan factores de degradación de mensajeros (enzimas de decapping, exonucleasas, etc). Por otro lado, frente a un estímulo de estrés los mensajeros se acumularán en SG. Se propone un intercambio dinámico de componentes entre estas estructuras. 


\section{Conclusiones finales}

Las conclusiones de esta tesis pueden resumirse en el modelo esquemático representado en la figura 51. Particularmente, hemos estudiado el metabolismo posttranscripcional de regulación de la expresión génica mediante la caracterización de complejos mRNP en Drosophila melanogaster. Los aportes originales de esta tesis son:

1- Las proteínas Lsm-1 y Me31B son componentes de los cuerpos de procesamiento en células S2 de Dm, sin embargo no forman parte de los gránulos de estrés.

2- Las proteínas eIF4E-1, eIF4E-2, eIF4E-3 y d4E-HP se encuentran en cuerpos de procesamiento en células $\mathrm{S} 2$ de $\mathrm{Dm}$, y también son encontradas en gránulos de estrés generados por tratamiento con arsenito de sodio.

3- La unión al cap de los mensajeros no es necesaria para la localización de eIF4E en PB y SG.

4- El residuo triptófano 117 de eIF4E-1 (y los equivalentes en las otras isoformas, correspondiente al W73 de la ortóloga en humanos) es necesario para la correcta localización en PB y SG.

5- La proteína Me31B interacciona directamente con la proteína eIF4E en PB de células $\mathrm{S} 2$ in vivo.

6- La proteína Lsm-1 interacciona directamente con la proteína eIF4E en PB de células S2 in vivo. 


\section{Perspectivas futuras}

La regulación de la traducción de los mensajeros es uno de los procesos más importantes en diferentes condiciones fisiológicas en los organismos, ya que es el más rápido de todos los procesos de regulación de la expresión génica. Ampliar aún más el conocimiento en éstas áreas nos permitirá, además de comprender mejor este mecanismo, poder evaluar condiciones particulares, incluso patológicas.

Queda para estudios futuros determinar específicamente los sitios de interacción entre Me31B y eIF4E, ya que creemos que es una de las interacciones más importantes para el remodelamiento de mRNP en Dm. Asimismo, ampliar la caracterización de estas complejas estructuras de silenciamiento (PB y SG), ampliando la lista de factores componentes de los mismos. De la misma manera, nos interesa completar el modelo de remodelamiento planteado, para lo cuál es fundamental continuar con el estudio de interacciones entre los componentes de PB. 
4. Materiales y Métodos 


\section{Extracción de ARN de células}

Se parte de dos frascos de células $\mathrm{S} 2$ de $D m$ de $25 \mathrm{~cm}^{2}$ saturados. Se lavan las células con PBS y se agrega buffer de lisis con $\beta$-mercaptoetanol, se colecta en un tubo plástico de $13 \mathrm{ml}$. Se repite el paso anterior. Se agrega igual volumen de fenol y se mezcla por inversión, se agrega 1/4 volumen de cloroformo:isoamílico (24:1), se invierte y se centrifuga 5 min a $13.200 \mathrm{rpm}$, se toma la fase superior y se la coloca en otro tubo. Se agrega igual volumen de etanol absoluto y se centrifuga 10 min a 13.200 rpm, se elimina el sobrenadante y se lava el pellet con etanol $80 \%$. Este se disuelve en agua mili Q con $\mathrm{LiCl} 12 \mathrm{M}$, y se deja $30 \mathrm{~min}$ a $-20 \mathrm{C}$ y posteriormente se centrifuga 15 min a $13.200 \mathrm{rpm}$. Se lava el pellet con etanol $80 \%$ y se resuspende en agua mili Q. 5 $\mu 1$ se usaron para chequear la integridad del ARN en gel de agarosa 1,5\% con bromuro de etidio (ver material suplementario).

\section{Producción de ADNc}

Para la síntesis del ADNc se utilizo el kit SMART cDNA Library Construction Kit (BD biosciences). Esta estrategia proporciona un método para generar genotecas de ADNc de alta calidad, a partir de nanogramos de ARN total o poli A+: 


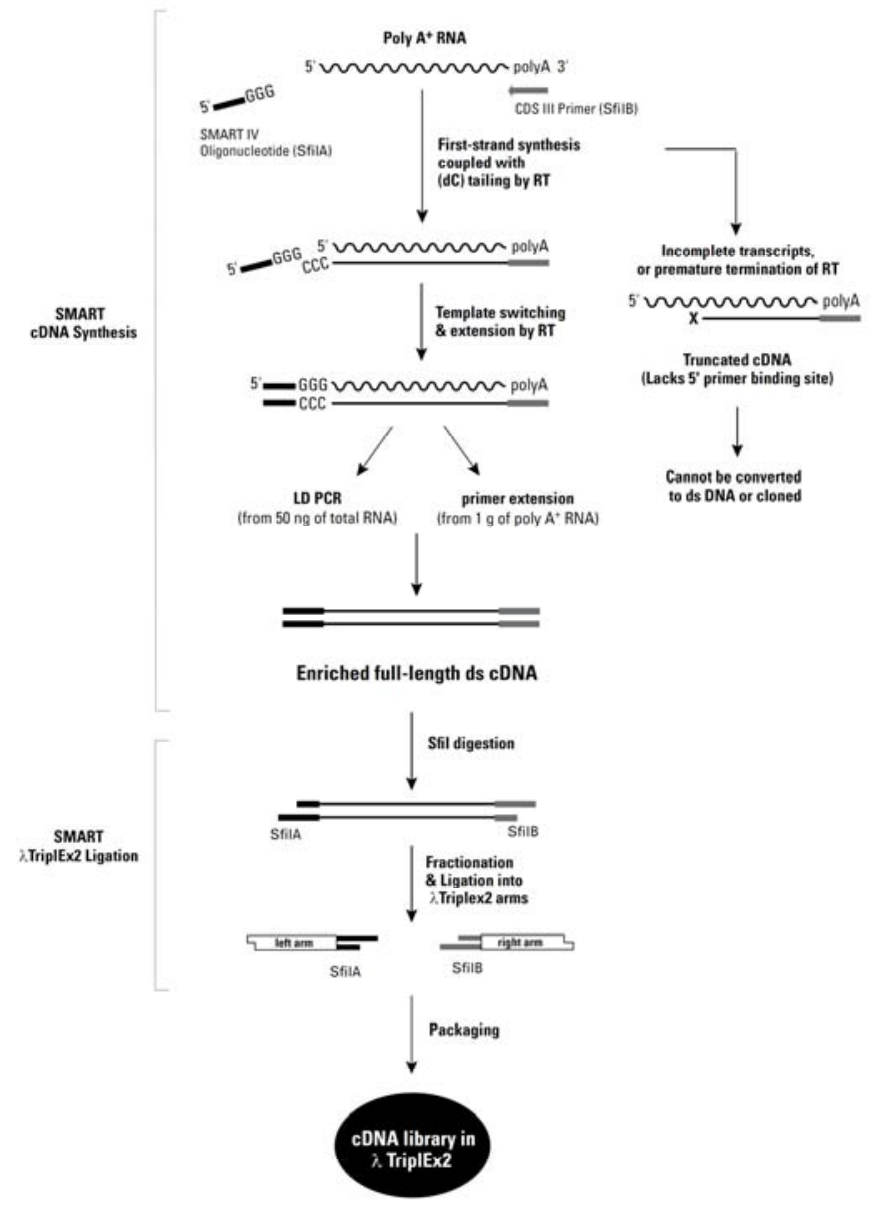

Se utilizo 1,23 $\mu \mathrm{g}$ de ARN total, el cual sirvió de molde para la síntesis de ADNsc por medio de la transcriptasa reversa y un cebador de tipo oligo dT (CDS III/3' PCR Primer). Este cuenta con una secuencia que permite la identificación de cada una de las genotecas generadas (indicado abajo como N_1N-) y un sitio SfiI-A para clonado direccional. Así el oligonucleótido resultante es:

5'-ATTCTAGAGGCCGAGGCGGCCGACATG-d(T) ${ }_{30} \mathrm{~N}_{-1} \mathrm{~N}-3^{\prime}$

Para la síntesis de la primera cadena de $\mathrm{ADNc}$ se procedió de la siguiente manera: 1,5 $\mu 1$ de ARN total $(1,23 \mu \mathrm{g}), 1 \mu 1$ de CDS III/3' primer, $1 \mu 1$ de SmartIV oligonucleótido, se llevo a un volumen final de $5 \mu 1$ con agua mili Q. Se incubó por 2 min a $72^{\circ} \mathrm{C}$, y luego en hielo por otros 2 min. Luego a la mezcla se le agrego $2 \mu 1$ de $5 \mathrm{X}$ Firsth-Strand Buffer, $1 \mu 1$ de DTT $(20 \mathrm{mM}), 1 \mu 1$ de dNTP Mix (10mM) y $1 \mu 1$ de 
Power Script reverse Transcriptase. La mezcla se incubo a $42^{\circ} \mathrm{C}$ por $1 \mathrm{~h}$, y luego se colocó en hielo para terminar la síntesis. $5 \mu 1$ de ADNc simple cadena se sembraron en un gel de agarosa 1,5\% con bromuro de etidio para determinar la abundancia y calidad del producto. La segunda cadena se genero por el método LD-PCR usando el primer con el oligo dT mencionado arriba y un primer adaptador en el extremo 5' (5'PCR primer, el cual cuenta con un sitio de restricción para la enzima Sfi1-B) según el siguiente esquema de reacción:

$\begin{array}{rll}2 \mu \mathrm{l} & \text { First-Strand cDNA (from Step A.10) } \\ 80 \mu \mathrm{l} & \text { Deionized } \mathrm{H}_{2} \mathrm{O} \\ 10 \mu \mathrm{l} & \text { 10X Advantage 2 PCR Buffer } \\ 2 \mu \mathrm{l} & \text { 50X dNTP Mix } \\ 2 \mu \mathrm{l} & \text { 5' PCR Primer } \\ 2 \mu \mathrm{l} & \text { CDS III/3' PCR Primer } \\ 2 \mu \mathrm{l} & \text { 50X Advantage 2 Polymerase Mix } \\ 100 \mu \mathrm{l} & \text { Total volume }\end{array}$

El programa de PCR utilizado para la síntesis de ADNc doble cadena es el siguiente: $20 \operatorname{seg} 95^{\circ} \mathrm{C} \rightarrow 18 \mathrm{X}\left(5 \operatorname{seg} .95^{\circ} \mathrm{C} \rightarrow 6 \min .68^{\circ} \mathrm{C}\right)$. El producto obtenido por esta estrategia se purificó mediante el sistema QuiaQuick PCR Purification Kit (Clontech), el ADN se eluyó en $100 \mu 1$ de agua mili Q. $5 \mu 1$ se usaron para chequear la integridad del ADNc en gel de agarosa 1,5\% con bromuro de etidio.

\section{Reacción en cadena de la polimerasa (PCR)}

Se utilizaron tres protocolos diferentes de PCR dependiendo del tamaño del fragmento a amplificar:

1)- Fragmentos < 1000 pb: se utilizó la enzima Taq polimerasa (PB-L). Las mezclas de reacción se prepararon con 2,5 U de enzima $T a q$ en el buffer de reacción correspondiente con una concentración de $500 \mu \mathrm{M}$ de desoxinucleótidos (dATP, dCTP, dGTP y dTTP), $1 \mu \mathrm{M}$ de cada oligonucleótido, $1,25 \mathrm{mM}$ de $\mathrm{Mg}^{+2}$ y $100 \mathrm{ng}$ de ADNc de células S2 de Drosophila melangaster, en un volumen final de reacción de $10 \mu$ l. El programa general de ciclado utilizado consistió en un primer paso de 
desnaturalización del $\mathrm{ADN}\left(5 \mathrm{~min}\right.$ a $\left.94^{\circ} \mathrm{C}\right), 30$ ciclos con los pasos de desnaturalización (30 seg a $94^{\circ} \mathrm{C}$ ), hibridación (60 seg a la temperatura indicada) y extensión (el tiempo indicado a $72^{\circ} \mathrm{C}$ ) y un último paso de extensión $\left(10\right.$ min a $\left.72^{\circ} \mathrm{C}\right)$ para completar productos no terminados.

2)- Fragmentos ente $1000-1800$ pb: se utilizó la enzima Pfx-platinum ADN polimerasa (invitrogen). Las reacciones de amplificación se realizaron con $1 \mathrm{U}$ de enzima $P f x$ en el buffer de reacción correspondiente (BSA $1 \mathrm{mg} / \mathrm{ml}, \mathrm{MgSO}_{4} 1,2 \mathrm{mM}$ ) con una concentración de $500 \mu \mathrm{M}$ de desoxinucleótidos (dATP, dCTP, dGTP y dTTP), $1 \mu \mathrm{M}$ de cada oligonucleótido, $625 \mu \mathrm{M}$ de $\mathrm{Mg}^{+2}$ y $100 \mathrm{ng}$ de ADN (ADNc de células S2 de Drosophila melangaster o ADN plasmídico), en un volumen final de reacción de 10 $\mu$ l. El programa general de ciclado utilizado consistió en un primer paso de desnaturalización del $\mathrm{ADN}\left(5 \min\right.$ a $\left.94^{\circ} \mathrm{C}\right), 30$ ciclos con los pasos de desnaturalización (30 seg a $94^{\circ} \mathrm{C}$ ), hibridación (60 seg a la temperatura indicada) y extensión (el tiempo indicado a $68^{\circ} \mathrm{C}$ ) y un último paso de extensión $\left(10\right.$ min a $68^{\circ} \mathrm{C}$ ) para completar productos no terminados.

3)- Fragmentos > 1800 pb: se utilizó el sistema enzimático Expand Long Template PCR System (Roche). Las mezclas de reacción consisten en 0,75 U de enzima en el buffer de reacción correspondiente con una concentración de $350 \mu \mathrm{M}$ de desoxinucleótidos (dATP, dCTP, dGTP y dTTP), 0,3 $\mu \mathrm{M}$ de cada oligonucleótido, 1,25 mM de $\mathrm{Mg}^{+2}$ y $100 \mathrm{ng}$ de ADNc de células S2 de Drosophila melanogaster, en un volumen final de reacción de $10 \mu \mathrm{l}$. El programa general de ciclado utilizado consistió en un primer paso de desnaturalización del ADN (2 min a 93 C), 30 ciclos con los pasos de desnaturalización (20 seg a 93 C), hibridación (30 seg a la temperatura indicada) y extensión (el tiempo indicado a $68^{\circ} \mathrm{C}$ ) y un último paso de extensión $\left(5 \min\right.$ a $\left.68^{\circ} \mathrm{C}\right)$ para completar productos no terminados.

Para los tres protocolos de PCR utilizados la temperatura de hibridación se fijó $2^{\circ} \mathrm{C}$ por debajo de la temperatura de Melting $\left(\mathrm{Tm}=2^{\circ} \mathrm{C} \times(\mathrm{A}+\mathrm{T})+4^{\circ} \mathrm{C} \times(\mathrm{G}+\mathrm{C})\right)$ menor del par de oligonucleótidos, en algunos casos particulares se hicieron modificaciones de dicha temperatura basándose en los resultados experimentales. El tiempo de 
extensión se calculó en base al fragmento de $\mathrm{ADN}$ a amplificar, considerando un tiempo de polimerización de $2 \mathrm{~min} / \mathrm{Kb}$.

\section{Electroforesis en geles de agarosa}

Las electroforesis en geles de agarosa para separar fragmentos de ADN se realizaron de acuerdo a los protocolos descriptos por Sambrook y Russell (Sambrook and Russell, 2001). Se utilizaron como patrones de peso molecular los marcadores de 100 pb y $\lambda$ Hind III (PB-L).

\section{Purificación de ADN de geles de agarosa}

La purificación de bandas de geles de agarosa se realizó utilizando el kit Qiagen II (Qiagen Inc.) según indicaciones del fabricante.

En otros casos se utilizo una modificación del protocolo de extracción descripto por Sambrook y Russell (Sambrook and Russell, 2001): se colocó el fragmento de gel en un tubo eppendorff de $0,5 \mathrm{ml}$ con el fondo perforado y relleno de lana de vidrio. Se colocó este sobre un tubo de 1,5ml vacío y se centrifugó 1 min a 13.000rpm. Se agregó al sobrenadante anterior 0,1 vol de $\mathrm{LiCl} 0,8 \mathrm{M}$ y 3 vol de etanol. Se incubó $30 \mathrm{~min} \mathrm{a} \mathrm{-}$ $80^{\circ} \mathrm{C}$. Finalmente se centrifugó $30 \mathrm{~min}$ a $13000 \mathrm{rpm}$ a $4^{\circ} \mathrm{C}$, se descartó el sobrenadante, se lavó con etanol $70 \%$ y se resuspendió en agua.

\section{Fosforilación de fragmentos de ADN}

Se utilizó la enzima T4 polinucleotido quinasa (Fermentas). La mezcla de reacción se generó en un volumen final de 30 ul con 1 unidad de enzima T4 polinucleotido quinasa, 3mM de ATP, 0,5mM ADN y el buffer correspondiente (para fragmentos con extremos romos: $50 \mathrm{mM}$ Tris- $\mathrm{HCl} \mathrm{PH}$ 7., $10 \mathrm{mM} \mathrm{MgCl}_{2}, 5 \mathrm{mM}$ DTT, 0.5mM espermidina, 0,5mM EDTA; para fragmentos con extremos cohesivos: $50 \mathrm{mM}$ de imidazol-HCl PH 6.4, 18mM $\mathrm{MgCl}_{2}$, 5mM DTT, 0.5mM espermidina, 0,5mM EDTA y $0,5 \mathrm{mM}$ ADP), y para el caso de fosforilación de fragmentos con extremos cohesivos 
se procedió al adicionamiento de PGE 6000 . Se incubó a $37^{\circ} \mathrm{C}$ durante 30 minutos (para extremos romos) o 60 minutos (para extremos cohesivos).

\section{Digestión de ADN con enzimas de restricción}

Se emplearon $5 \mathrm{U}$ de enzima por $\mu \mathrm{g}$ de $\mathrm{ADN}$, en el buffer y a la temperatura indicada para cada enzima según instrucciones del fabricante (Fermentas).

\section{Desfosforilación de plásmidos cortados con enzimas de restricción.}

Para $25 \mu \mathrm{g}$ de plásmido se emplearon $5 \mathrm{U}$ de enzima CIAP (Calf Intestinal Alkaline Phosphatase, Invitrogen) en su correspondiente buffer (50 mM Tris- $\mathrm{HCl}(\mathrm{pH} 8.5), 0.1$ mM EDTA) en un volumen final de $50 \mu$, y se incubó la mezcla a $37^{\circ} \mathrm{C}$ por 3 minutos.

\section{Ligación de fragmentos de ADN}

Se preparó el vector plasmídico digiriendo con la enzima de restricción indicada. En el caso de vectores digeridos con una sola enzima de restricción, se realizó la remoción de fosfatos $5^{\prime}$ terminales con fosfatasa alcalina (CIAP, Invitrogen) para evitar religación del vector sin inserto durante la ligación, utilizando $1 \mathrm{U}$ de enzima cada 5 $\mu \mathrm{g}$ de plásmido en su correspondiente buffer ( $50 \mathrm{mM}$ Tris- $\mathrm{HCl}(\mathrm{pH} 8.5), 0.1 \mathrm{mM}$ EDTA) en un volumen final de $50 \mu$, y se incubó la mezcla a $37^{\circ} \mathrm{C}$ por 3 minutos.

Se purificó el ADN mediante electroforesis. Para la reacción de ligación se mezclaron $50 \mathrm{ng}$ de vector con el inserto de interés, en distintas relaciones molares. Se utilizó el kit de ligación (Rapid DNA Dephos. \& Ligation Kit, Roche), primero el ADN se diluyó en el buffer de dilución y luego se agregó el buffer de reacción y 5 U de la enzima T4 ADN ligasa, según indicaciones del fabricante, y en un volumen final de 20 $\mu 1$. Se incubó 5-15 min a temperatura ambiente. Los amplicones obtenidos mediante PCR fueron clonados utilizando el vector de clonación Topo Blunt (Invitrogen), y en el vector de expresión pECFP-C1 y pEYFP-C1 a excepción del caso de eIF4E que se utilizó el vector pLP-EYFP-C1, de acuerdo a las instrucciones provistas por el fabricante. 


\section{Transformación de bacterias competentes}

Se transformaron $50 \mu \mathrm{l}$ de bacterias competentes, preparadas con el método de $\mathrm{CaCl}_{2}$, utilizando shock térmico, con la mitad de la mezcla de reacción de ligación, o 50 ng de plásmido purificado, según las condiciones descriptas en el trabajo de Inoue y colaboradores (Inoue et al., 1990). Se dejó en hielo $30 \mathrm{~min}$, se incubó por $30 \mathrm{seg}$ a $42^{\circ} \mathrm{C}$ y luego 3 min en hielo. Se recuperaron las bacterias en $900 \mu \mathrm{l}$ de medio LB durante $1 \mathrm{~h}$ a $37^{\circ} \mathrm{C}$ con agitación y se sembraron en placas de Petri con medio LB agar conteniendo $30 \mu \mathrm{g} / \mathrm{ml}$ de kanamicina.

\section{Purificación de ADN de plásmidos}

Cultivos bacterianos crecidos 16 h se cosecharon por centrifugación a 5000 rpm durante $5 \mathrm{~min}$. El pellet bacteriano se resuspendió en $150 \mu \mathrm{l}$ de TELT y $50 \mu \mathrm{l}$ de lisozima, se incubó $2 \min$ a $100^{\circ} \mathrm{C}$ e inmediatamente $2 \min$ en baño de hielo, produciendo la lisis de las bacterias. Luego se centrifuga $10 \mathrm{~min}$ a $13200 \mathrm{rpm}$. Al sobrenadante obtenido se le agrega $150 \mu \mathrm{l}$ de alcohol isopropílico y se centrifuga nuevamente $10 \mathrm{~min}$ a $13200 \mathrm{rpm}$. El pellet conteniendo el ADN se resuspende en 20 $\mu l$ de agua. La concentración se estimó comparando con concentraciones conocidas de ADN del Fago $\lambda$ corridos en geles de agarosa. Para obtener ADN de mayor pureza, utilizado para secuenciar las construcciones y para transfectar, se realizaron ensayos de mini prep con kit (illustra ${ }^{\mathrm{TM}}$ plasmidPrep Mini Spin Kit, GE Healthcare).

\section{Bacterias}

El clonado y la expresión de proteínas de fusión se realizó utilizando las cepas de bacterias E. coli DH5 $\alpha$. Las bacterias se crecieron en medio LB (Sambrook and Russell, 2001). 


\section{Clonación}

Para la clonación de los fragmentos de PCR se procedió según el siguiente esquema experimental:

Purificación de fragmentos de geles de agarosa

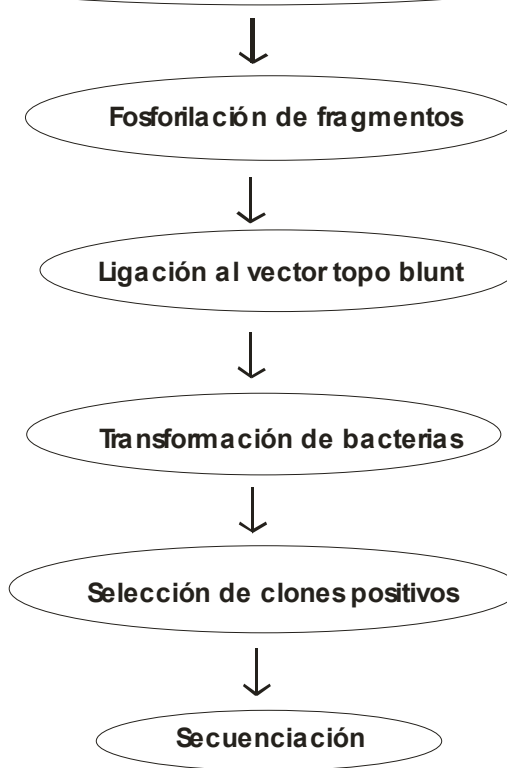

\section{Generación de vectores capaces de expresar proteínas de fusión fluorescentes}

A partir de los clones obtenidos en el vector topo blunt (Invitrogen) se procedió así:

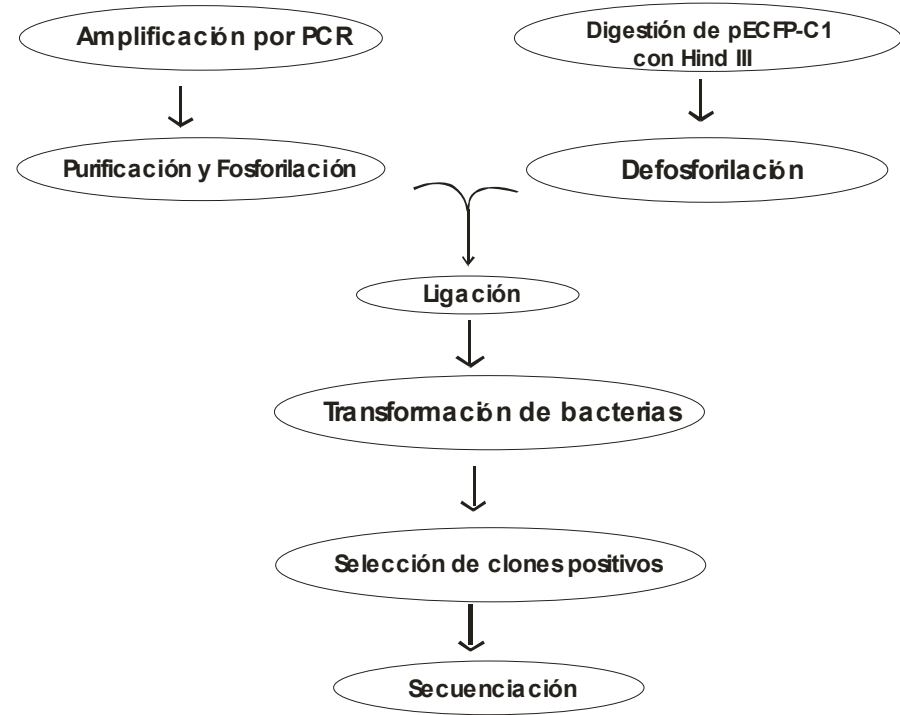




\section{Líneas celulares utilizadas}

Células S2 de Drosophila melanogaster crecidas a $28^{\circ} \mathrm{C}$ en medio Schneider (Schneider's insect medium, Sigma) suplementado con SFB 10\% (Natocor) inactivado por calor, penicilina $100 \mathrm{U} / \mathrm{ml}$, estreptomicina $100 \mu \mathrm{g} / \mathrm{ml}$ (Gibco), glutamina 2mM (glutamax, Gibco).

Células HeLa fueron cultivadas en medio DMEM suplementado con SFB 10\% (Natocor) inactivado por calor, penicilina $100 \mathrm{U} / \mathrm{ml}$, estreptomicina $100 \mu \mathrm{g} / \mathrm{ml}$ y en atmosfera con $5 \% \mathrm{CO}_{2}$.

\section{Inmuno histoquímica}

Para realizar las tinciones con anticuerpos las células previamente fijadas con PFA 4\% son lavadas con PBS y permeabilizadas mediante el tratamiento con PBS- tritón 0,5\% durante 5min, posteriormente se bloquea con BSA-PBTw durante $30 \mathrm{~min}$, luego se incuba con el anticuerpo primario (0,5 - 3hs) diluído en la solución de bloqueo. Se lava 3 veces con PBTw 20\% y se incuba con el anticuerpo secundario 30min, se hacen 3 lavados con PBTw, las células se secan por aspiración y los vidrios son montados en mowiol, se dejan secar a $4^{\circ} \mathrm{C} 16$ hs para ser visualizados microscópicamente.

\section{Transfección de células}

Para realizar las transfecciones de ambas líneas celulares se utilizó lipofectamina (Lipofectamine $^{T M} 2000$ Reagent, Invitrogen) en una relación de $1 \mu \mathrm{g}$ cada $250 \mathrm{ng}$ de plásmido a transfectar. Se preparó por un lado la dilución del plásmido en medio sin suero y por otro lado la dilución del reactivo, también en medio sin suero, se incubó 5 min a temperatura ambiente y luego ambas soluciones se mezclaron y fueron incubadas por otros 20 min. Finalmente la mezcla de reacción se agregó sobre células en crecimiento y se incubó por una hora. Pasado este tiempo se elimino el medio, se agregó medio completo y las células se dejaron en crecimiento por $48 \mathrm{hs}$. 


\section{Mutagénesis sitio dirigida}

La mutagénesis dirigida de eIF4E-1 y eIF4E-3 en los sitios de unión al cap (W100 y W146 y dobles mutantes) se llevó a cabo a través de la secuencia clonada en el plásmido pMT/V5-His (Invitrogen) o pECFP-C1 (Clontech) respectivamente. Los triptófanos 100 y 146 fueron sustituidos por alanina. En particular, el mutante eIF4E$1^{\mathrm{W} 117 \mathrm{~A}}$ se generó a partir del la construcción pCS-eIF4E-1. Se llevo a cabo la amplificación por PCR de cada molde, generando mutaciones puntuales en eIF4E, con el uso de los siguientes oligonucleótidos:

eIF4E-1 ${ }_{\text {fwd }}^{\text {W100A }}$ 5'CGGTCCAAGAGCGCTGAGGACATGCAAAACGAG 3'

eIF4E-1 ${ }_{\text {rev }}^{\text {W100A }}$ 5'CTGTTTGTGGGTTGCATCTTCGGCCAGGGGACG 3'

eIF4E-1 ${ }_{\text {fwd }}^{\text {w117A }}$ 5'GATACCGTCGAGGACTTCGCGAGCCTATACAACCACATC 3' eIF4E-1 ${ }_{\text {rev }}^{\text {W117A }}$ 5'GATGTGGTTGTATAGGCTCGCGAAGTCCTCGACGGTATC 3 '

eIF4E-1 ${ }_{\text {fwd }}^{\mathrm{W} 146 \mathrm{~A}}$ :

5'GCTATTCAAGAACATTCGTCCCATGGCCGAGGATGCAGCCAACAAACAGGGC 3 ' eIF4E-1 ${ }_{\text {rev }}^{\text {W146A }}$

5'GCCCTGTTTGTTGGCTGCATCCTCGGCCATGGGACGAATTTCTTCTTGAATAGC 3 '

eIF4E-3 ${ }^{\mathrm{F} 103 \mathrm{Awd}}$ : 5'ACTCCTGAAGCGGTCACACATGATGAAACAC 3'

eIF4E-3 ${ }_{\text {rev }}^{\text {F103A }}$ 5'GTGTTTCATCATGTGTGACCGCTTCAGGAGT 3'

Además, los sitios de restricción para HaeII y EaeI, se crearon en W100A y W146A para identificar posteriormente a los mutantes.

\section{Preparación de células fijadas para ensayos de FRET}

1. Se colocó un cubreobjetos redondo en cada uno de los 24 pocillos de una placa (Costar), sobre estos se colocaron $2 \times 10^{5}$ células en medio completo, se dejó el tiempo necesario para que las mismas se adhieran al cubreobjeto (2-4hs) y se transfectó con los plásmidos elegidos. 
2. Las células se crecieron en medio completo el tiempo necesario para la expresión de las proteínas (48hs).

3. Se lavaron las células dos veces con PBS, se aspiraron y luego se agregó paraformaldehído 4\%. Se incubó 10 minutos a temperatura ambiente para fijar las células. Se lavó rápidamente con 50 mM Tris (pH 8.0) $100 \mathrm{mM} \mathrm{NaCl}$ para eliminar el exceso de reactivo de fijación, se incubó otros 5 minutos (para apagar el resto de los grupos aldehído)

4. Se realizaron cinco lavados con PBS.

5. Se eliminó del exceso de PBS apoyando un extremo del cubreobjeto sobre una servilleta de papel.

6. Se realizó el montaje del cubreobjetos en $10 \mu \mathrm{l}$ de medio de montaje (Mowiol) sobre un portaobjetos de vidrio, y se dejó secar 16 hs a $4^{\circ} \mathrm{C}$.

\section{Medida de la eficiencia de FRET}

Todos los datos fueron obtenidos en un microscopio confocal meta LSM 510 (Zeiss). Las muestras fueron fijadas con 4\% PFA y las imágenes adquiridas con un objetivo 63 X / 1,4 W (Zeiss). La excitación de las proteínas de fusión CFP se efectuaron con el láser $458 \mathrm{~nm}$ con 30mW Argón (transmisión AOTF25\%) y la recolección de la luz emitida con un filtro de paso de banda 480/20. Ninguna emisión de las proteínas de fusión YFP se detectó en este canal. Las imágenes fueron tomadas antes y después del fotoblanqueo de la señal de YFP utilizando exactamente la misma sensibilidad y ajustes. Fueron seleccionadas regiones de interés (ROIs) y se cuantificó la señal en las mismas. El fotoblanqueo de YFP se realizó con el láser de alta potencia de excitación a $514 \mathrm{~nm}$ con un láser de $50 \mathrm{~mW}$ de estado sólido.

Imágenes de la proteína de fusión YFP que expresan las células se obtuvieron antes y después fotoblanqueo por la excitación con argón de $30 \mathrm{~mW} / 2$ láser (transmisión 5\%) en la excitación de $514 \mathrm{~nm}$ y la emisión de recogida de $530 \mathrm{~nm}$ a $600 \mathrm{~nm}$. No se observó fotoblanqueo de la señal de la proteína CFP en condiciones de foto destrucción $>90 \%$ de la señal de YFP. 
La eficiencia de FRET se calculo para cada PB por separado:

$$
E=\frac{F_{D 1}-F_{D 0}}{F_{D 0}},
$$

donde $F_{D 0}, F_{D 1}$ corresponden a la intensidad de los donantes, previa y posterior al fotoblanqueo, en un $\mathrm{PB}$ respectivamente.

Se utilizó el método de fotoblanqueo del aceptor. Este método calcula la eficiencia de FRET indirectamente, midiendo un cambio cuando no ocurre FRET (en las áreas en las que se realizó fotoblanqueo). Se eligió este método debido a que elimina el entrecruzamiento de señales de excitación y emisión (ya que elimina las moléculas aceptoras). Se utilizó la configuración multi track del microscopio (cada track se activa secuencialmente prendiendo sólo el detector y el láser correspondiente al fluoróforo seleccionado) ya que reduce notablemente el cruzamiento de las señales.

\section{Alineamiento de secuencias}

El alineamiento de secuencias fue realizado utilizando el algoritmo CLUSTAL W (Thompson et al., 1994).

\section{Modelado por homología y generación de archivos de Docking}

Se realizó el modelado por homología utilizando el programa Modeller (Eswar et al., 2006; Marti-Renom et al., 2000). Se utilizó una combinación de los programas VMD (Visual Molecular Dynamics) y NAMD (Scalable Molecular Dynamics) para realizar la minimización de energía de los modelos (Humphrey et al., 1996). Finalmente los modelos fueron evaluados mediante Ramachandran Plot y DOPE Score.

Para llevar a cabo la simulación se utilizó el paquete autogrid4 y autodock4. Se realizó un ranking por energía libre de interacción y RMSD para seleccionar el mejor de todos los modelos resultado de la simulación. El modelo elegido fue analizado con el programa $M G L-T o o l s$, y se visualizaron residuos cercanos y puentes hidrógeno. 
Para evaluar lo parámetros que se utilizaron en la simulación se realizaron controles que consistieron en re-ensamblar co-cristales obtenidos de la base de datos de RCSB (pdb: protein data bank). 
5. Material Suplementario 


\section{Oligonucleótidos utilizados}

\begin{tabular}{|c|c|c|}
\hline Proteína & Oligonucléotido & Secuencia (5' a ' $^{\prime}$ ) \\
\hline Lsm-1 & CG4279f & ATGGACGACTTAAATCCGTG \\
\hline & CG4279r & TTAGCAGAAGTCCTCGTTGAT \\
\hline Me31b & CG4916RAf & ATGATGACTGAAAAGTAAATTC \\
\hline & CG4916RAr & TTATTTGCTAACGTTGCCCTCCTC \\
\hline Bruno & CG31759f & ATGGGTTTTTTTGTTAAAAAC \\
\hline & CG31759r & TCATGACTTAAATTTGAGATC \\
\hline elF4E-T & CG32016f & ATGATAAAAGTGGATATGAGG \\
\hline & CG32016r & TTAGTTATGCACGACGCCTGAG \\
\hline Ccr4 & CG31137RCf & ATGTGTATCTTTAAAAAAGAGAC \\
\hline & CG31137RCr & CTACCGGCGATTGATGACC \\
\hline Cup & CG1181f & ATGGACCCTATGAAAGAGGAG \\
\hline & CG1181r & TTAATGAAACTCATCCCCGTCG \\
\hline Agol & CG6671RAf & ATGTCCACGGAGCGTGAGC \\
\hline & CG6671RAr & TTAGGCAAAGTACATGACCTTC \\
\hline Agoll & CG7439RBf & ATGGGAAAAAAGATAAGAACAAG \\
\hline & CG7439RBr & TCAGACAAAGTACATGGGGTT \\
\hline Xrn1 & CG3291 & ATGGGCGTTCCCAAGTTCTTC \\
\hline & CG3291 & TTAAGTTGGATGCGGGGAGTC \\
\hline elF4E & elF4E1-W100Af & CGGTCCAAGAGCGCTGAGGACATGCAAACGAG \\
\hline & elF4E1-W100Ar & CTGTTTGTGGGTTGCATCTTCGGCCAGGGGACG \\
\hline & elF4E1-W117Af & GATACCGTCGAGGACTTCGCCTATACAACCACATC \\
\hline & elF4E1-W117Ar & GATGTGGTTGTATAGGCTCGCGAAGTCCTCGACGGTATC \\
\hline & elF4E1-W147Af & GCTATTCAAGAACATTCGTCCCATGGCCGAGGATGCAGCCAACAAACAGGGC \\
\hline
\end{tabular}

\section{Anticuerpos utilizados}

\begin{tabular}{c|c|c|c} 
Anticuerpo & Especie & Dilución utilizada & Marca \\
\hline anti-V5 & ratón & $1 / 1000$ & Invitrogen \\
\hline anti-Dcp1 & ratón & $1 / 100$ y $1 / 500$ & Abnova Corporation \\
\hline anti-Xrn1 & conejo & $1 / 100$ y $1 / 500$ & Bethyl laoratories \\
\hline anti-rck/p54 (DDX6) & conejo & $1 / 500$ & Bethyl laoratories \\
\hline anti-Ge-1 (RCD8) & conejo & $1 / 100$ y $1 / 500$ & Bethyl laoratories \\
\hline anti-GW182 & ratón & $1 / 250$ & Abcam \\
\hline anti-Tia1 & conejo & $1 / 500$ & Abcam \\
\hline anti-elF4E & conejo & $1 / 500$ & Abcam
\end{tabular}




\section{Vectores utilizados}

\begin{tabular}{|c|c|c|}
\hline Vector & Marca & Uso \\
\hline pCR-Blunt II-TOPO & invitrogen & $\begin{array}{c}\text { clonación de fragmentos de } \\
\text { PCR }\end{array}$ \\
\hline pEYFP-C1 & clontech & $\begin{array}{l}\text { generación de proteínas de } \\
\text { fusión } \\
\text { generación de proteínas de }\end{array}$ \\
\hline pECFP-C1 & clontech & $\begin{array}{l}\text { fusión } \\
\text { generación de proteínas de }\end{array}$ \\
\hline pLP-EYFP-C1 & clontech & fusión \\
\hline pMT/V5-HisC & invitrogen & clonación de elF4E \\
\hline pCS2+ & invitrogen & clonación de elF4E \\
\hline
\end{tabular}

\section{ARN extraído de células S2}

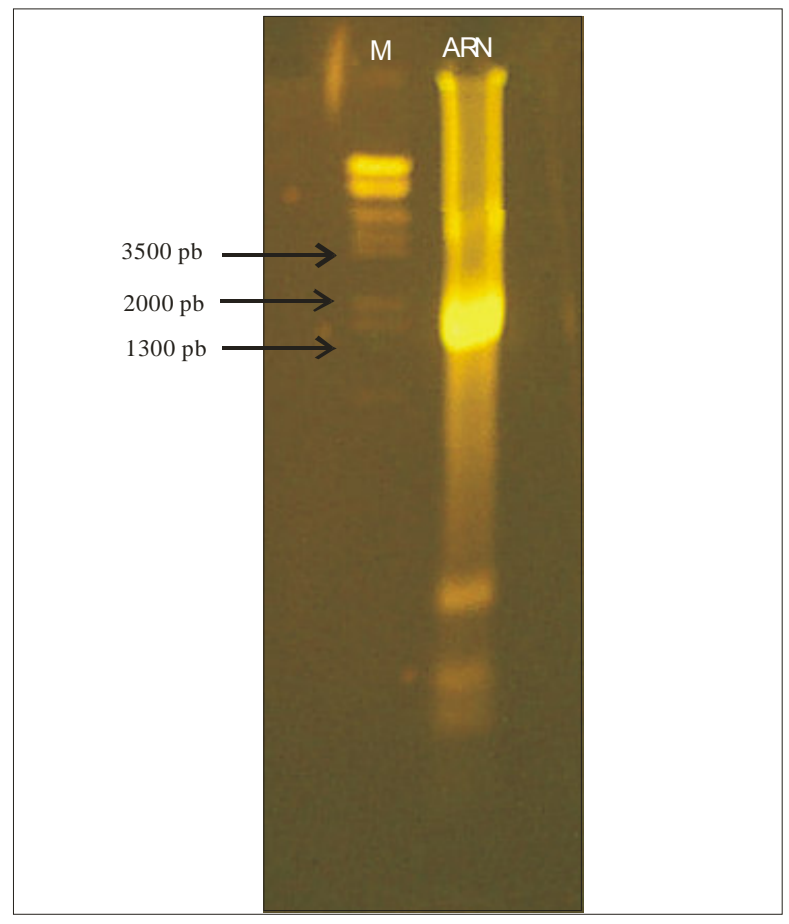

ARN de células S2 de Drosophila melanogaster 
Secuencias utilizadas para el modelado de proteínas

Me31B (Drosophila melanogaster):

secuencia completa, extensión 459 a.a., desde Metionina (M, Met) 1 a la Lisina (K, Lys) 459:

MMTEKLNSGHTNLTSKGI INDLQIAGNT SDDMGWKSKLKLPP KDNRFKTTDVTDTRGNEFEEFCLKRELLMGIFE KGWERP SP IQEAAIP IALSGKDVLARAKNGTGKTGAYCIPVLEQIDPTKDYIQALVMVPTRELALQTSQICIELA KHLDIRVMVTTGGTILKDDILRIYQKVQLI IATPGRILDLMDKKVADMSHCRILVLDEADKLLSLDFQGMLDHVI LKLPKDPQILLF SATFPLTVKNFMEKHLREPYEINLMEELTLKGVTQYYAFVQERQKVHCLNTLF SKLQINQS II FCNSTQRVELLAKKITELGYCCYY IHAKMAQAHRNRVFHDFRQGLCRNLVCSDLFTRGIDVQAVNVVINFDFPRM AETYLHRIGRSGRFGHLGIAINLITYEDRFDLHRIEKELGTEIKP IPKVIDPALYVANVGASVGDTCNNSDLNNS ANEEGNVSK

a.a. N-terminales no modelados, extensión 57 a.a., desde Metionina (M, Met) 1 a la Glicina (G, Gly) 57:

MMTEKLNSGHTNLTSKGI INDLQIAGNTSDDMGWKSKLKLPPKDNRFKTTDVTDTRG

secuencia modelada, extensión 375 a.a., desde Asparagina (N, Asn) 58 a la Alanina (A, Ala) 432:

NEFEEFCLKRELLMGIFEKGWERP SP IQEAA IP IALSGKDVLARAKNGTGKTGAYCIPVLEQ IDP TKDYIQALVM VPTRELALQTSQICIELAKHLD IRVMVTTGGT I LKDD I LR I YQKVQL I IATP GR I LDLMDKKVADMSHCR I LVLD EADKLLSLDFQGMLDHVILKLPKDPQ I LLF SATFP LTVKNFMEKHLREPYE INLMEELTLKGVTQYYAFVQERQK VHCLNTLF SKLQINQS I IFCNSTQRVELLAKKI TELGYCCYY I HAKMAQAHRNRVF HDFRQGLCRNLVCSDLFTR GIDVQAVNVVINFDFPRMAETYLHRI GRSGRFGHLGIA INLITYEDRFDLHRIEKELGTE IKP IPKVIDPALYVA

a.a. C-terminales no modelados, extensión 27 a.a., desde Asparagina (N, Asn) 433 a la Lisina (K, Lys) 459:

NVGASVGDTCNNSDLNNSANEEGNVSK

eIF4E (Drosophila melanogaster):

secuencia completa, extensión 259 a.a., desde Metionina (M, Met) 1 a la Leucina ( $L$, Leu) 259:

MQSDF HRMKNF ANP KSMFKTSAP STEQGRPEPP TSAAAPAEAKDVKP KEDPQETGEPAGNTATTTAPAGDDAVRT EHLYKHP LMNVWTLWYLENDRSKSWEDMQNEITSFDTVEDFWSLYNH IKPP SE IKLGSDYSLFKKNIRPMWEDAA NKQGGRWVITLNKS SKTDLDNLWLDVLLCLIGEAFDHSDQICGAVINIRGKSNKI S IWTADGNNEEAALE I GHKL RDALRLGRNNSLQYQLHKDTMVKQGSNVKSIYTL

a.a. N-terminales no modelados, extensión 70 a.a., desde Metionina (M, Met) 1 al Aspartico (D, Asp) 70:

MQSDF HRMKNE ANPKSMFKTSAP STEQGRPEPP TSAAAPAEAKDVKP KEDPQETGEPAGNTATTTAPAGD

secuencia modelada, extensión 189 a.a., desde Aspartico (D, Asp) 71 a la la Leucina (L, Leu) 259:

DAVRTEHLYKHP LMNVWTLWYLENDRSKSWEDMQNE I TSFDTVEDFWSLYNH IKPP SE IKLGSDYSLFKKNIRPM WEDAANKQGGRWV I TLNKSSKTDLDNLWLDVLLCL I GEAFDHSDQICGAVIN IRGKSNK I S IWTADGNNEEAALE IGHKLRDALRLGRNNSLQYQLHKDTMVKQGSNVKSIYTL 


\section{Referencias}


Adams, S.R., A.T. Harootunian, Y.J. Buechler, S.S. Taylor, and R.Y. Tsien. 1991. Fluorescence ratio imaging of cyclic AMP in single cells. Nature. 349:694-697.

Almudi, I., M. Corominas, and F. Serras. 2010. Competition between SOCS36E and Drk modulates Sevenless receptor tyrosine kinase activity. J Cell Sci. 123:3857-3862.

Altmann, M., C. Handschin, and H. Trachsel. 1987. mRNA cap-binding protein: cloning of the gene encoding protein synthesis initiation factor eIF-4E from Saccharomyces cerevisiae. Mol Cell Biol. 7:998-1003.

Amiri, A., B.D. Keiper, I. Kawasaki, Y. Fan, Y. Kohara, R.E. Rhoads, and S. Strome. 2001. An isoform of eIF4E is a component of germ granules and is required for spermatogenesis in C. elegans. Development. 128:3899-3912.

Amrani, N., M.S. Sachs, and A. Jacobson. 2006. Early nonsense: mRNA decay solves a translational problem. Nat Rev Mol Cell Biol. 7:415-425.

Anderson, P., and N. Kedersha. 2006. RNA granules. J Cell Biol. 172:803-808.

Anderson, P., and N. Kedersha. 2008. Stress granules: the Tao of RNA triage. Trends Biochem Sci. 33:141-150.

Andrei, M.A., D. Ingelfinger, R. Heintzmann, T. Achsel, R. Rivera-Pomar, and R. Luhrmann. 2005. A role for eIF4E and eIF4E-transporter in targeting mRNPs to mammalian processing bodies. Rna. 11:717-727.

Baez, M.V., and G.L. Boccaccio. 2005. Mammalian Smaug Is a Translational Repressor That Forms Cytoplasmic Foci Similar to Stress Granules. Journal of Biological Chemistry. 280:43131-43140.

Balagopal, V., and R. Parker. 2009. Polysomes, P bodies and stress granules: states and fates of eukaryotic mRNAs. Curr Opin Cell Biol. 21:403-408.

Barbee, S.A., P.S. Estes, A.M. Cziko, J. Hillebrand, R.A. Luedeman, J.M. Coller, N. Johnson, I.C. Howlett, C. Geng, R. Ueda, A.H. Brand, S.F. Newbury, J.E. Wilhelm, R.B. Levine, A. Nakamura, R. Parker, and M. Ramaswami. 2006. Staufen- and FMRPcontaining neuronal RNPs are structurally and functionally related to somatic $\mathrm{P}$ bodies. Neuron. 52:997-1009.

Bashkirov, V.I., H. Scherthan, J.A. Solinger, J.M. Buerstedde, and W.D. Heyer. 1997. A mouse cytoplasmic exoribonuclease (mXRN1p) with preference for G4 tetraplex substrates. J Cell Biol. 136:761-773.

Bastiaens, P.I.H., and A. Squire. 1999. Fluorescence lifetime imaging microscopy: spatial resolution of biochemical processes in the cell. Trends in Cell Biology. 9:48-52.

Bastiaens, P.1.H., I.V. Majoul, P.J. Verveer, H.D. Soling, and T.M. Jovin. 1996. Imaging the intracellular trafficking and state of the AB5 quaternary structure of cholera toxin. Embo J. 15:4246-4253.

Betzig, E., G.H. Patterson, R. Sougrat, O.W. Lindwasser, S. Olenych, J.S. Bonifacino, M.W. Davidson, J. Lippincott-Schwartz, and H.F. Hess. 2006. Imaging intracellular fluorescent proteins at nanometer resolution. Science. 313:1642-1645.

Blackstock, W.P., and M.P. Weir. 1999. Proteomics: quantitative and physical mapping of cellular proteins. Trends in Biotechnology. 17:121-127.

Bolte, S., and F.P. CordeliÈRes. 2006. A guided tour into subcellular colocalization analysis in light microscopy. Journal of Microscopy. 224:213-232.

Brengues, M., and R. Parker. 2007. Accumulation of polyadenylated mRNA, Pab1p, eIF4E, and eIF4G with P-bodies in Saccharomyces cerevisiae. Mol Biol Cell. 18:2592-2602.

Brengues, M., D. Teixeira, and R. Parker. 2005. Movement of eukaryotic mRNAs between polysomes and cytoplasmic processing bodies. Science. 310:486-489.

Browning, K.S. 1996. The plant translational apparatus. Plant Molecular Biology. 32:107144. 
Buchan, J.R., D. Muhlrad, and R. Parker. 2008. P bodies promote stress granule assembly in Saccharomyces cerevisiae. J Cell Biol. 183:441-455.

Buchan, J.R., and R. Parker. 2009. Eukaryotic Stress Granules: The Ins and Outs of Translation. Mol Cell. 36:932-941.

Buchan, J.R., J.H. Yoon, and R. Parker. 2011. Stress-specific composition, assembly and kinetics of stress granules in Saccharomyces cerevisiae. J Cell Sci. 124:228-239.

Coller, J., and R. Parker. 2004. Eukaryotic mRNA decapping. Annu Rev Biochem. 73:861890.

Coller, J., and R. Parker. 2005. General translational repression by activators of mRNA decapping. Cell. 122:875-886.

Conti, E., and E. Izaurralde. 2005. Nonsense-mediated mRNA decay: molecular insights and mechanistic variations across species. Curr Opin Cell Biol. 17:316-325.

Cooper, M., L. Johnston, and J. Beggs. 1995. Identification and characterization of Ussip (Sdb23p): a novel U6 snRNA-associated protein with significant similarity to core proteins of small nuclear ribonucleoproteins. Embo J. 14:2066-2075.

Cougot, N., S. Babajko, and B. Seraphin. 2004. Cytoplasmic foci are sites of mRNA decay in human cells. J Cell Biol. 165:31-40.

Chan, S.P., and F.J. Slack. 2006. microRNA-Mediated Silencing Inside P-Bodies. RNA Biology. 3:97-100.

Cho, P.F., C. Gamberi, Y.A. Cho-Park, I.B. Cho-Park, P. Lasko, and N. Sonenberg. 2006. Cap-dependent translational inhibition establishes two opposing morphogen gradients in Drosophila embryos. Curr Biol. 16:2035-2041.

Cho, P.F., F. Poulin, Y.A. Cho-Park, I.B. Cho-Park, J.D. Chicoine, P. Lasko, and N. Sonenberg. 2005. A new paradigm for translational control: inhibition via 5'-3' mRNA tethering by Bicoid and the eIF4E cognate 4EHP. Cell. 121:411-423.

De Gregorio, E., J. Baron, T. Preiss, and M.W. Hentze. 2001. Tethered-function analysis reveals that elF4E can recruit ribosomes independent of its binding to the cap structure. Rna. 7:106-113.

de Valoir, T., M.A. Tucker, E.J. Belikoff, L.A. Camp, C. Bolduc, and K. Beckingham. 1991. A second maternally expressed Drosophila gene encodes a putative RNA helicase of the "DEAD box" family. Proceedings of the National Academy of Sciences. 88:21132117.

Derry, M.C., A. Yanagiya, Y. Martineau, and N. Sonenberg. 2006. Regulation of poly(A)binding protein through PABP-interacting proteins. Cold Spring Harb Symp Quant Biol. 71:537-543.

Dostie, J., M. Ferraiuolo, A. Pause, S.A. Adam, and N. Sonenberg. 2000. A novel shuttling protein, 4E-T, mediates the nuclear import of the mRNA 5' cap-binding protein, eIF4E. The EMBO journal. 19:3142-3156.

Elion, E.A. 2001. Detection of Protein-Protein Interactions by Coprecipitation. In Current Protocols in Molecular Biology. John Wiley \& Sons, Inc.

Eswar, N., B. Webb, M.A. Marti-Renom, M.S. Madhusudhan, D. Eramian, M.Y. Shen, U. Pieper, and A. Sali. 2006. Comparative protein structure modeling using Modeller. Curr Protoc Bioinformatics. Chapter 5:Unit 56.

Eulalio, A., I. Behm-Ansmant, and E. Izaurralde. 2007a. P bodies: at the crossroads of posttranscriptional pathways. Nat Rev Mol Cell Biol. 8:9-22.

Eulalio, A., I. Behm-Ansmant, D. Schweizer, and E. Izaurralde. 2007b. P-body formation is a consequence, not the cause, of RNA-mediated gene silencing. Mol Cell Biol. 27:39703981.

Eystathioy, T. 2003. The GW182 protein colocalizes with mRNA degradation associated proteins hDcp1 and hLSm4 in cytoplasmic GW bodies. Rna. 9:1171-1173. 
Ferraiuolo, M.A., S. Basak, J. Dostie, E.L. Murray, D.R. Schoenberg, and N. Sonenberg. 2005. A role for the eIF4E-binding protein 4E-T in P-body formation and mRNA decay. J Cell Biol. 170:913-924.

Fields, S., and O.-k. Song. 1989. A novel genetic system to detect protein-protein interactions. Nature. 340:245-246.

Forler, D., T. Kocher, M. Rode, M. Gentzel, E. Izaurralde, and M. Wilm. 2003. An efficient protein complex purification method for functional proteomics in higher eukaryotes. Nat Biotech. 21:89-92.

Förster, T. 1948. Zwischenmolekulare Energiewanderung und Fluoreszenz. Annalen Der Physik. 437:55-75.

Franks, T.M., and J. Lykke-Andersen. 2008. The control of mRNA decapping and P-body formation. Mol Cell. 32:605-615.

French, A.P., S. Mills, R. Swarup, M.J. Bennett, and T.P. Pridmore. 2008. Colocalization of fluorescent markers in confocal microscope images of plant cells. Nat Protoc. 3:619628.

Gadella Jr, T.W.J., T.M. Jovin, and R.M. Clegg. 1993. Fluorescence lifetime imaging microscopy (FLIM): Spatial resolution of microstructures on the nanosecond time scale. Biophysical Chemistry. 48:221-239.

Giepmans, B.N., S.R. Adams, M.H. Ellisman, and R.Y. Tsien. 2006. The fluorescent toolbox for assessing protein location and function. Science. 312:217-224.

Gingras, A.C., B. Raught, and N. Sonenberg. 1999. eIF4 initiation factors: effectors of mRNA recruitment to ribosomes and regulators of translation. Annu Rev Biochem. 68:913963.

Gordon, G.W., G. Berry, X.H. Liang, B. Levine, and B. Herman. 1998. Quantitative Fluorescence Resonance Energy Transfer Measurements Using Fluorescence Microscopy. Biophys J. 74:2702-2713.

Hein, B., K.I. Willig, and S.W. Hell. 2008. Stimulated emission depletion (STED) nanoscopy of a fluorescent protein-labeled organelle inside a living cell. Proceedings of the National Academy of Sciences. 105:14271-14276.

Heintzmann, R., and G. Ficz. 2007. Breaking the resolution limit in light microscopy. Methods Cell Biol. 81:561-580.

Hermann, H., P. Fabrizio, V. Raker, K. Foulaki, H. Hornig, H. Brahms, and R. Luhrmann. 1995. snRNP Sm proteins share two evolutionarily conserved sequence motifs which are involved in Sm protein-protein interactions. The EMBO journal 14 2076-2088.

Hernandez, G., M. Altmann, J.M. Sierra, H. Urlaub, R. Diez del Corral, P. Schwartz, and R. Rivera-Pomar. 2005. Functional analysis of seven genes encoding eight translation initiation factor 4E (eIF4E) isoforms in Drosophila. Mech Dev. 122:529-543.

Hernandez, G., and J.M. Sierra. 1995. Translation initiation factor eIF-4E from Drosophila: cDNA sequence and expression of the gene. Biochim Biophys Acta. 1261:427-431.

Hernandez, G., and P. Vazquez-Pianzola. 2005. Functional diversity of the eukaryotic translation initiation factors belonging to eIF4 families. Mech Dev. 122:865-876.

Hernandez, G., P. Vazquez-Pianzola, J.M. Sierra, and R. Rivera-Pomar. 2004a. Internal ribosome entry site drives cap-independent translation of reaper and heat shock protein 70 mRNAs in Drosophila embryos. Rna. 10:1783-1797.

Hernandez, G., P. Vazquez-Pianzola, A. Zurbriggen, M. Altmann, J.M. Sierra, and R. RiveraPomar. 2004b. Two functionally redundant isoforms of Drosophila melanogaster eukaryotic initiation factor 4B are involved in cap-dependent translation, cell survival, and proliferation. Eur J Biochem. 271:2923-2936.

Hillebrand, J., S.A. Barbee, and M. Ramaswami. 2007. P-body components, microRNA regulation, and synaptic plasticity. ScientificWorldJournal. 7:178-190. 
Humphrey, W., A. Dalke, and K. Schulten. 1996. VMD: visual molecular dynamics. J Mol Graph. 14:33-38, 27-38.

Ingelfinger, D., D.J. Arndt-Jovin, L. R.; and T. Achsel. 2002. The human LSm1-7 proteins colocalize with the mRNA-degrading enzymes Dcp1/2 and Xrnl in distinct cytoplasmic foci. Rna. 8:1489-1501.

Inoue, H., Nojima, H., and Okayama, H. 1990. High efficiency transformation of Escherichia coli with plasmids. Gene 96: 23-28.

Jackson, R.J., C.U. Hellen, and T.V. Pestova. 2010. The mechanism of eukaryotic translation initiation and principles of its regulation. Nat Rev Mol Cell Biol. 11:113-127.

Jares-Erijman, E.A., and T.M. Jovin. 2003. FRET imaging. Nat Biotechnol. 21:1387-1395.

Jones, S., and J.M. Thornton. 1996. Principles of protein-protein interactions. Proceedings of the National Academy of Sciences. 93:13-20.

Joshi, B., A. Cameron, and R. Jagus. 2004. Characterization of mammalian eIF4E-family members. Eur J Biochem. 271:2189-2203.

Kambach, C., S. Walke, R. Young, J.M. Avis, E. de la Fortelle, V.A. Raker, R. Luhrmann, J. Li, and K. Nagai. 1999. Crystal structures of two Sm protein complexes and their implications for the assembly of the spliceosomal snRNPs. Cell. 96:375-387.

Kedersha, N., G. Stoecklin, M. Ayodele, P. Yacono, J. Lykke-Andersen, M.J. Fritzler, D. Scheuner, R.J. Kaufman, D.E. Golan, and P. Anderson. 2005. Stress granules and processing bodies are dynamically linked sites of mRNP remodeling. $J$ Cell Biol. 169:871-884.

Kedersha, N.L., M. Gupta, W. Li, I. Miller, and P. Anderson. 1999. RNA-binding proteins TIA-1 and TIAR link the phosphorylation of eIF-2 alpha to the assembly of mammalian stress granules. J Cell Biol. 147:1431-1442.

Keiper, B.D., B.J. Lamphear, A.M. Deshpande, M. Jankowska-Anyszka, E.J. Aamodt, T. Blumenthal, and R.E. Rhoads. 2000. Functional characterization of five eIF4E isoforms in Caenorhabditis elegans. J Biol Chem. 275:10590-10596.

Lachance, P.E.D., M. Miron, B. Raught, N. Sonenberg, and P. Lasko. 2002. Phosphorylation of Eukaryotic Translation Initiation Factor 4E Is Critical for Growth. Mol Cell Biol. 22:1656-1663.

Lejeune, F., and L.E. Maquat. 2005. Mechanistic links between nonsense-mediated mRNA decay and pre-mRNA splicing in mammalian cells. Curr Opin Cell Biol. 17:309-315.

Leung, A.K., J.M. Calabrese, and P.A. Sharp. 2006. Quantitative analysis of Argonaute protein reveals microRNA-dependent localization to stress granules. Proc Natl Acad Sci U S A. 103:18125-18130.

Lin, M.D., X. Jiao, D. Grima, S.F. Newbury, M. Kiledjian, and T.B. Chou. 2008. Drosophila processing bodies in oogenesis. Dev Biol. 322:276-288.

Mann, M., R.C. Hendrickson, and A. Pandey. 2001. Analysis of proteins and proteomes by mass spectrometry. Annu Rev Biochem. 70:437-473.

Marcotrigiano, J., A.-C. Gingras, N. Sonenberg, and S.K. Burley. 1997. Cocrystal Structure of the Messenger RNA 5' Cap-Binding Protein (eIF4E) Bound to 7-methyl-GDP. Cell. 89:951-961.

Marcotrigiano, J., I.B. Lomakin, N. Sonenberg, T.V. Pestova, C.U. Hellen, and S.K. Burley. 2001. A conserved HEAT domain within eIF4G directs assembly of the translation initiation machinery. Mol Cell. 7:193-203.

Marti-Renom, M.A., A.C. Stuart, A. Fiser, R. Sanchez, F. Melo, and A. Sali. 2000. Comparative protein structure modeling of genes and genomes. Annu Rev Biophys Biomol Struct. 29:291-325.

Matsumoto, K., M. Minami, F. Shinozaki, Y. Suzuki, K. Abe, S. Zenno, S. Matsumoto, and Y. Minami. 2011. Hsp90 is involved in the formation of P-bodies and stress granules. Biochemical and Biophysical Research Communications. 407:720-724. 
Mayes, A., L. Verdone, P. Legrain, and J. Beggs. 1999. Characterization of Sm-like proteins in yeast and their association with U6 snRNA. Embo J. 18:4321-4331.

Medda, R., S. Jakobs, S.W. Hell, and J. Bewersdorf. 2006. 4Pi microscopy of quantum dotlabeled cellular structures. Journal of Structural Biology. 156:517-523.

Minshall, N., and N. Standart. 2004. The active form of Xp54 RNA helicase in translational repression is an RNA $\square$ mediated oligomer. Nucleic Acids Res. 32:1325-1334.

Nagy, P., G. Vámosi, A. Bodnár, S.J. Lockett, and J. Szöllősi. 1998. Intensity-based energy transfer measurements in digital imaging microscopy. European Biophysics Journal. 27:377-389.

Nakamura, A., R. Amikura, K. Hanyu, and S. Kobayashi. 2001. Me31B silences translation of oocyte-localizing RNAs through the formation of cytoplasmic RNP complex during Drosophila oogenesis. Development. 128:3233-3242.

Nakamura, A., K. Sato, and K. Hanyu-Nakamura. 2004. Drosophila Cup Is an eIF4E Binding Protein that Associates with Bruno and Regulates oskar mRNA Translation in Oogenesis. Developmental cell. 6:69-78.

Navarro, R.E., E.Y. Shim, Y. Kohara, A. Singson, and T.K. Blackwell. 2001. cgh-1, a conserved predicted RNA helicase required for gametogenesis and protection from physiological germline apoptosis in C. elegans. Development. 128:3221-3232.

Niedzwiecka, A., J. Marcotrigiano, J. Stepinski, M. Jankowska-Anyszka, A. WyslouchCieszynska, M. Dadlez, A.C. Gingras, P. Mak, E. Darzynkiewicz, N. Sonenberg, S.K. Burley, and R. Stolarski. 2002. Biophysical studies of eIF4E cap-binding protein: recognition of mRNA 5' cap structure and synthetic fragments of eIF4G and 4E-BP1 proteins. J Mol Biol. 319:615-635.

Niessing, D., N. Dostatni, H. Jackle, and R. Rivera-Pomar. 1999. Sequence interval within the PEST motif of Bicoid is important for translational repression of caudal mRNA in the anterior region of the Drosophila embryo. Embo J. 18:1966-1973.

Niessing, D., W. Driever, F. Sprenger, H. Taubert, H. Jackle, and R. Rivera-Pomar. 2000. Homeodomain position 54 specifies transcriptional versus translational control by Bicoid. Mol Cell. 5:395-401.

Ong, S.E., L.J. Foster, and M. Mann. 2003. Mass spectrometric-based approaches in quantitative proteomics. Methods. 29:124-130.

Pannone, B., D. Xue, and S. Wolin. 1998. A role for the yeast La protein in U6 snRNP assembly: evidence that the La protein is a molecular chaperone for RNA polymerase III transcripts. Embo J. 17:7442-7453.

Parker, R., and U. Sheth. 2007. P bodies and the control of mRNA translation and degradation. Mol Cell. 25:635-646.

Perutz, M.F., M.G. Rossmann, A.F. Cullis, H. Muirhead, G. Will, and A.C.T. North. 1960. Structure of Haemoglobin: A Three-Dimensional Fourier Synthesis at 5.5-[angst]. Resolution, Obtained by X-Ray Analysis. Nature. 185:416-422.

Piccioni, F., V. Zappavigna, and A.C. Verrotti. 2005. A Cup Full of Functions. RNA Biology. 2:125-128.

Preiss, T., and M. W. Hentze. 2003. Starting the protein synthesis machine: eukaryotic translation initiation. Bioessays. 25:1201-1211.

Rigaut, G., A. Shevchenko, B. Rutz, M. Wilm, M. Mann, and B. Seraphin. 1999. A generic protein purification method for protein complex characterization and proteome exploration. Nat Biotech. 17:1030-1032.

Rivera-Pomar, R., D. Niessing, U. Schmidt-Ott, W.J. Gehring, and H. Jackle. 1996. RNA binding and translational suppression by bicoid. Nature. 379:746-749.

Robalino, J., B. Joshi, S.C. Fahrenkrug, and R. Jagus. 2004. Two zebrafish eIF4E family members are differentially expressed and functionally divergent. J Biol Chem. 279:10532-10541. 
Salgado-Garrido, J., E. Bragado-Nilsson, S. Kandels-Lewis, and B. Seraphin. 1999. Sm and Sm-like proteins assemble in two related complexes of deep evolutionary origin. Embo J. 18:3451-3462.

Sambrook, J., and Russell, D.W. 2001. Molecular cloning: a laboratory manual. New York: Cold Spring Harbor Laboratory Press, Cold Spring Harbor.

Schneider, R., and M. Kozak. 2001. New Ways of Initiating Translation in Eukaryotes? Mol Cell Biol. 21:8238-8246.

Seraphin, B. 1995. Sm and Sm-like proteins belong to a large family: identification of proteins of the U6 as well as the U1, U2, U4 and U5 snRNPs. Embo J. 14:2089-2098.

Sheth, U., and R. Parker. 2003. Decapping and Decay of Messenger RNA Occur in Cytoplasmic

Processing Bodies. Science. 300:805-808.

Sonenberg, N., and T.E. Dever. 2003. Eukaryotic translation initiation factors and regulators. Current Opinion in Structural Biology. 13:56-63.

Sonenberg, N., and A.G. Hinnebusch. 2009. Regulation of translation initiation in eukaryotes: mechanisms and biological targets. Cell. 136:731-745.

Stevens, S.W., and J. Abelson. 1999. Purification of the yeast U4/U6.U5 small nuclear ribonucleoprotein particle and identification of its proteins. Proc. Natl. Acad. Sci. USA

96:7226-7231.

Stryer, L. 1978. Fluorescence Energy Transfer as a Spectroscopic Ruler. Annu Rev Biochem. 47:819-846.

Suzuki, Y., M. Minami, M. Suzuki, K. Abe, S. Zenno, M. Tsujimoto, K. Matsumoto, and Y. Minami. 2009. The Hsp90 inhibitor geldanamycin abrogates colocalization of eIF4E and eIF4E-transporter into stress granules and association of eIF4E with eIF4G. $J$ Biol Chem. 284:35597-35604.

Svitkin, Y.V., V.M. Evdokimova, A. Brasey, T.V. Pestova, D. Fantus, A. Yanagiya, H. Imataka, M.A. Skabkin, L.P. Ovchinnikov, W.C. Merrick, and N. Sonenberg. 2009. General RNA-binding proteins have a function in poly(A)-binding protein-dependent translation. Embo J. 28:58-68.

Teixeira, D., and R. Parker. 2007. Analysis of P-body assembly in Saccharomyces cerevisiae. Mol Biol Cell. 18:2274-2287.

Tharun, S., W. He, A.E. Mayes, P. Lennertz, J.D. Beggs, and R. Parker. 2000. Yeast Sm-like proteins function in mRNA decapping and decay. Nature. 404:515-518.

Tharun, S., and R. Parker. 2001. Targeting an mRNA for decapping: displacement of translation factors and association of the Lsm1p-7p complex on deadenylated yeast mRNAs. Mol Cell. 8:1075-1083.

Thomas, M.G., M. Loschi, M.A. Desbats, and G.L. Boccaccio. 2011. RNA granules: the good, the bad and the ugly. Cell Signal. 23:324-334.

Thomas, M.G., L.J. Martinez Tosar, M. Loschi, J.M. Pasquini, J. Correale, S. Kindler, and G.L. Boccaccio. 2005. Staufen recruitment into stress granules does not affect early mRNA transport in oligodendrocytes. Mol Biol Cell. 16:405-420.

Thomas, M.G., L.J.M. Tosar, M.A. Desbats, C.C. Leishman, and G.L. Boccaccio. 2009. Mammalian Staufen 1 is recruited to stress granules and impairs their assembly. $J$ Cell Sci. 122:563-573.

Thompson, J.D., D.G. Higgins, and T.J. Gibson. 1994. CLUSTAL W: improving the sensitivity of progressive multiple sequence alignment through sequence weighting, position-specific gap penalties and weight matrix choice. Nucleic Acids Res. 22:46734680.

Tomoo, K., X. Shen, K. Okabe, Y. Nozoe, S. Fukuhara, S. Morino, T. Ishida, T. Taniguchi, H. Hasegawa, A. Terashima, M. Sasaki, Y. Katsuya, K. Kitamura, H. Miyoshi, M. Ishikawa, and K.-i. Miura. 2002. Crystal structures of 7-methylguanosine 5'- 
triphosphate (m(7)GTP)- and P(1)-7-methylguanosine-P(3)-adenosine-5',5'triphosphate $(\mathrm{m}(7) \mathrm{GpppA})$-bound human full-length eukaryotic initiation factor 4E: biological importance of the C-terminal flexible region. Biochem. J. 362:539-544.

Tourriere, H., K. Chebli, L. Zekri, B. Courselaud, J.M. Blanchard, E. Bertrand, and J. Tazi. 2003. The RasGAP-associated endoribonuclease G3BP assembles stress granules. $J$ Cell Biol. 160:823-831.

van Dijk, E., N. Cougot, S. Meyer, S. Babajko, E. Wahle, and B. Seraphin. 2002. Human Dcp2: a catalytically active mRNA decapping enzyme located in specific cytoplasmic structures. EMBO J. 21:6915-6924.

Vazquez-Pianzola, P., G. Hernandez, B. Suter, and R. Rivera-Pomar. 2007. Different modes of translation for hid, grim and sickle mRNAs in Drosophila. Cell Death Differ. 14:286-295.

Vazquez-Pianzola, P., H. Urlaub, and R. Rivera-Pomar. 2005. Proteomic analysis of reaper 5' untranslated region-interacting factors isolated by tobramycin affinity-selection reveals a role for La antigen in reaper mRNA translation. Proteomics. 5:1645-1655.

Verveer, P.J., and P.I. Bastiaens. 2008. Quantitative microscopy and systems biology: seeing the whole picture. Histochem Cell Biol. 130:833-843.

Whalen, S.G., A.-C. Gingras, L. Amankwa, S. Mader, P.E. Branton, R. Aebersold, and N. Sonenberg. 1996. Phosphorylation of eIF-4E on Serine 209 by Protein Kinase C Is Inhibited by the Translational Repressors, 4E-binding Proteins. Journal of Biological Chemistry. 271:11831-11837.

Wilczynska, A., C. Aigueperse, M. Kress, F. Dautry, and D. Weil. 2005. The translational regulator CPEB1 provides a link between dcp1 bodies and stress granules. J Cell Sci. 118:981-992.

Wouters, F.S., P.J. Verveer, and P.I. Bastiaens. 2001. Imaging biochemistry inside cells. Trends Cell Biol. 11:203-211.

Xenarios, I., and D. Eisenberg. 2001. Protein interaction databases. Current Opinion in Biotechnology. 12:334-339.

Yamasaki, S., and P. Anderson. 2008. Reprogramming mRNA translation during stress. Curr Opin Cell Biol. 20:222-226.

Zekri, L., E. Huntzinger, S. Heimstadt, and E. Izaurralde. 2009. The silencing domain of GW182 interacts with PABPC1 to promote translational repression and degradation of microRNA targets and is required for target release. Mol Cell Biol. 29:6220-6231. 